\title{
BIBLIOGRAFÍA
}

ObSERVACIONES: Las reseñas se consignan a continuación del libro (o artículo) reseñado. Cuando éste se ha descrito en una entrega anterior de la Bibliografia, se pone entre paréntesis el número de ficha correspondiente. También se hacen referencias a ediciones anteriores de una obra, a tomos anteriores de una obra en curso de publicación, etc. En estos casos, la cifra que precede al número de referencia indica el volumen de la NRFH en que figura la ficha en cuestión. Así, el "núm. 49-39695" corresponde a la ficha 39695, la cual está en el volumen 49 de la NRFH. Cuando no hay cifra inicial, ha de entenderse que el numero remite a una ficha incluida en el presente fascículo.

\section{LINGÜÍSTICA HISPÁNICA}

\section{OBRAS GENERALES}

53-1. Ableilata, Mohamed - "El hispanismo en el mundo árabe". - FGL, 2003, núms. 33/34, 99-105.

53-2. Avgllo, Felipe - "Ciencias, lengua y proyecto americanista desde Europa. Cartas de un bogotano a un porteño en el siglo XIx". - Carav, 2003, núm. 81, 147-162.

53-3. Asevjo, F. G. - "Intersubjectivity and empathy in Iberian letters and languages". - Studies in honor of Denah Lida, eds. M. G. Berg \& Lanin A. Gyurko (Potomac, Maryland, 2005), pp. 270-279.

53-4. Barriga Villanueva, Rebeca - "El mapa de producción lingüística de Lope Blanch". - Disquisiciones sobre filología hispánica. In memoriam Juan M. Lope Blanch (México, 2004), pp. $55-63$.

53-5. Bodenmeleter, Thomas, Thomas M. Scheerer \& Axei. Schönberger (edd.) - Romane in Spanien. T. 1: 1975-
2000. - Valentia, Frankfurt/M., 2004. 327 pp. (Bibliotheca Romanica et Latina, 4).

53-6. Bollée, Aviegret \& Ivgrid NetMANi-Holzschl一 - Spanische Sprachgeschichte. - Ernst Klett, Stuttgart, 2003. 176 pp. II RGG, 10 (2004), 233234 (Frings).

53-7. Betrina, Jeav, Mercè Montagut \& M. Licísa Ordóñez - "Sobre les Regles d'esquivar vocables i "La questió de la llengua»". - RFE, 83 (2003), 281-290.

533-8. Campos Glardado, Maria del ReflGIO - "Juan M. Lope Blanch y el Anuario de Letras". - Disquisiciones sobre filología hispánica. In memoriam Juan M. Lope Blanch (México, 2004), pp. 81-84.

53-9. Caratedo, Rocío - "Principios del cambio lingüístico. Una contribución sincrónica a la lingüústica histórica". - $R F E, 83$ (2003), 39-62.

53-10. Casado, MaNcel y ANTONiO Vilarxovo - "Eugenio Coseriu in memoriam". - AEF, 26 (2003), 5-11.

53-11. Clenca, María Josep y Joseph HiLFERTY - Introducción a la lingüística 
cognitiva. - Ariel, Barcelona, 1999. 256 pp. II BICC, 54 (1999), 326-331 (Cisneros Estupiñán).

53-12. Dhacont, Dlava - "El hispanismo en Rumania: desarrollo y estado actual". - Ibero, 2003, núm. 11, 205-225.

53-13. Espasa, Aitoni, Javier Girón y Davel PeÑa - "El valor económico de la lengua española”. - FGL, 2003, núms. 33/34, 247-257.

53-14. Fradejas Lebrero, José - "Una carta de doña Carolina Michaelis". RFE, 83 (2003), 161-167.

53-15. Jamieson, Martín - "Bibliografía de tesis inéditas sobre el español de Panamá (1994-2001)". - ALM, 40 (2002), 393-410.

ว3-16. LaRA, Llis Fervando - "Lope y el principio de realidad". - Disquisiciones sobre filologia hispánica. In memoriam Juan $M$. Lope Blanch (México, 2004), pp. 119-123.

53-17. Lope Blanch, Jlan M. - Estudio y edición de las "Osservationi della lingua castigliana”. - UNAM, México, 1998. II ALHis, 17/18 (2001-02), 275-277 (Peñalver Castillo).

53-18. López Morales, Humberto - "Varia lección de Juan Miguel Lope Blanch". - Disquisiciones sobre filologia hispánica. In memoriam Juan $M$. Lope Blanch (México, 2004), pp. 133-137.

53-19. Maqleo, Aia María - "Lope: el universitario". - Disquisiciones sobre filologia hispánica. In memoriam Juan $M$. Lope Blanch (México, 2004), pp. 139141.

53-20. Montes Giraldo, José Joaqlíx "Confusión de «lengua» y «lenguaje», ¿otro aspecto del imperialismo mundializante?". - BICC, 53 (1998), 553-560.

53-21. Moreno Cabrera, J. C. - La dignidad de las lenguas. Crítica de la discriminación lingüistica (N. 50-228). $\|$ RFilR, 20 (2003), 292-296 (Juárez Morena).

53-22. Morexo de Alba, José G. - "Juan

M. Lope Blanch: un estudioso de la lengua española". - Disquisiciones sobre filologia hispánica. In memoriam Juan M. Lope Blanch (México, 2004), pp. 143-149.

53-23. Molre, Teresa - Universales del lenguaje y linguo-diversidad. - Ariel,
Barcelona, 2001. 221 pp. II BLin, 2003, núm. 20, 61-65 (Guirado).

53-24. Oliner del Olmo, Sonia - "Setting up a Corpus-based study of Hedging in Spanish research articles: Creating a valid corpus". - ELAp, 2004, núm. 39, 81-92.

53-25. Ontanón de Lore, Paciencha "Semblanza". - Disquisiciones sobre filologia hispánica. In memoriam Juan $M$. Lope Blanch (México, 2004), pp. 151152.

53-26. Othegey, Ricirdo - "Las piedras nerudianas se tiran al norte: meditaciones lingüísticas sobre Nueva York". - Ins, 2003, núms. 679/680, 13-19.

53-27. Padilia Gáliez, Jesús - "La reglamentación del lenguaje mediantes las lenguas de especialidad". ALM, 40 (2002), 7-21.

53-28. Quilis, Avтonio - La lengua espanola en el mundo. - Universidad, Valladolid, 2002. 172 pp. II ALHis, $17 / 18$ (2001-02), 287-292 (Hoyos). 53-29. Ramírez, Luis AlfoNso - "El estudio interdisciplinario del lenguaje". - BICC, 53 (1998), 472-488.

53-30. Rojas Nieto, Cecilia - "Caminos abiertos a la investigación. La vigencia de las porpuestas metodológicas de Juan M. Lope Blanch". - Disquisiciones sobre filología hispánica. In memoriam Juan M. Lope Blanch (México, 2004), pp. 179-183.

53-31. Sánchez Ron, José Manuel "Ciencia y lenguaje". - FGL, 2003, núms. 33/34, 57-70.

53-32. Schütz, Génther - "Acerca de Ángel Cuervo". - BICC, 53 (1998), 104-114.

53-33. Soares da Silva, Auglsto (ed.) Linguagem e cognição. A perspectiva da linguistica cognitiva. - Associação Portuguesa de Linguística-Universidade Católica Portuguesa, Braga, 2001. 518 pp. II ALM, 40 (2002), 417423 (Arias-Quaglia Arduino).

53-34. Stefaio, LuClàA DE - "Ángel Rosenblat": - BLin, 2003, núm. 19, 86-96.

53-35. Villaseñor, Llis, Alrelio López, Manuel Montes y Cialda Vazelez "Tratamiento automático de textos 
en español". - ELAp, 2003, núm. 38, 145-166.

\section{HOMENAJES Y ACTAS DE CONGRESOS}

53-36. Báez, Gloria Estela y Elizabeth

Llia Traill (coords.) - Disquisiciones sobre filologia hispánica. In memoriam Juan $M$. Lope Blanch. - UNAM, México, 2004. $250 \mathrm{pp}$.

53-37. Barriga Villanueva, R. y P. Martíx Butragueño (eds.) - Varia lingüistica y literaria. T. 1: Lingüística (N. 46-18). II BICC, 53 (1998), 404-426 (Cisneros Estupiñán). - V. núm. 49-32.

53-38. Collès, Lcc, Jean-Lolis Dlfays, Geneviève Fabry \& Constantino MaeDER (eds.) - Didactique des langues romanes. Le développement de compétences chez l'apprenant. Actes du colloque de Louvain-La-Neuve,janvier 2000. - De Boeck Duculot, Bruxelles, 2001. 621 pp. II $R F, 115$ (2003), 111-113 (Cruz Piñol).

53-39. ENglebert, ANvick et al. (eds.) Actes du XXIIe Congrès International de Linguistique et de Philologie Romanes. T. 1: L'histoire de la linguistique, médiatrice de théories. Travaux de la section "Histoire de la Linguistique". Index des auteurs. Table générale des volumes I-IX. T. 6: De la grammaire des formes à la grammaire du sens. Travaux de la section "Morphologie et Syntaxe". T. 7: Sens et fonctions. Travaux de la section "Semantique et Pragmatique". - Niemeyer, Tübingen, 2000. II $R F, 115$ (2003), 521-522 (Dworkin).

53-40. Frank, Christoph \& Sylvaine Hä̀SEL. (Hrsg.) - Shunien und Portugal im Zeitzller der Aufklärung. Internationales Symposium der Carl Justi-Vereinigung und des Forschungszentrums Europäische Aufklärung Potsdam, 19.-22. Februar 1998. - Vervuert, Frankfurt/M., 2002. 605 pp. II Ibero, 2003, núm. 12, 225-227 (Floeck).

53-41. Habler, Gerda \& Peter Schmitter (eds.) - Sprachdiskussion und Beschreibung von Sprachen im 17. und 18. Jarhubdert. Beiträge der X. Internationalen Tagung des Studienkreises Geschichte der Sprachwissenschaft, 18.-21.Juni 1997 in
Postdam. - Nodus, Münster, 1999. 502 pp. II $R F, 115$ (2003), 263-265 (Schönberger).

53-42. Kremer, D. (ed.) - Homenaxe a Ramón Lorenzo (N. 47-1663). II ZRPh, 119 (2003), 738-741 (Kabatek).

53-43. Oesterricher, Wulf, Eva Stoll y Andreas Wesch (eds.) - Competencia escrita, tradiciones discursivas y variedades lingüisticas. Aspectos del español europeo y americano de los siglos XVI y XVII. Coloquio Internacional, Friburgo en Brisgovia, 26-28 de septiembre de 1996. Narr, Tübingen, 1998.444 pp. II ZRPh, 119 (2003), 708-710 (Brumme).

53-44. Perl, M. y K. PörtL - Identidad cultural y lingüistica en Colombia, Venezuela y en el Caribe hispánico. Actas del Segundo Congreso Internacional del Centro de Estudios Latinoamericanos (CELA) de la Universidad de Maguncia, en Germersheim, 23-27 de junio de 1997 (N. 51-31). II $R F, 115$ (2003), 412-413 (Schönberger).

53-45. Radtke, E. \& H. Thux (Hrgs.) Neue Wege der romanischen Geolinguistik: Akten des Symposiums zur empirischen Dialektologie, Heidelberg/Mainz 21.-24.101991 (N. 48-47). II BICC, 53 (1998), 369-383 (Montes Giraldo).

53-46. Sánchez Miret, Fernando (ed.) Actas del XXIII Congreso Internacional de Lingüistica y Filologia Románica. Salamanca, 24-390 de septiembre de 2001. T. 1: Conferencias plenarias. Fonética y fonología. Morfología. T. 2.1: Sintaxis, semántica y pragmática. T. 2.2: Sintaxis, semántica y pragmática. T. 3: Semántica léxica, lexicología y onomástica. T. 4: Edición y crítica textual. Retórica, poética y teoría literaria. T. 5: Lingüística aplicada. Historia de la lingüistica. Mesas redondas. - Max Niemeyer, Tübingen, 2003. lii + 2827 pp.

53-47. StAIB, BrLno (ed.) - Linguistica romanica et indiana. Festchrift für Wolf Dietrich zum 60. Gerburtstag. - Narr, Tübingen, 2000. xxv $+639 \mathrm{pp}$. $\| R F$, 115 (2003), 549-550 (Schönberger). 53-48. WüEST, Јаков (ed.) - Les linguistes suisses et la variation linguistique. Actes d'un colloque organisé á l'occasion du centenaire du Séminaire des langues romanes de l'Université de Zurich. - Francke, Ba- 
sel-Tübingen, 1997. 166 pp. II VR, 62 (2003), 216-225 (Fryba-Reber).

53-49. Zwartes, Otto \& Even HovdhatGEN (eds.) - Missionary linguistics/ Lingüistica misionera. Selected papers from the first International Conference of Missionary Linguistics, Oslo, 13-16 March 2003. - J. Benjamins, Amsterdam-Philadelphia, 2004. 288 pp. (Amsterdam Studies in the Theory and History of Lingusitic Science. Series III. Studies in the History of the Language Sciences, 106).

\section{GRAFÍA}

53-50. Gimeno Blay, Francisco M. - "Regola a fare letre antiche. A propósito de un tratado de caligrafía del Quattrocento italiano". - Syntagma, 2002, núm. 0, 47-72.

53-šl. Mora Monroy, Siervo Cistodio "Sobre la cambiante ortografía". BICC, 53 (1998), 572-574.

53-52. Ortega VillaseNor, Humberto "Árbol de la vida: en los orígenes de la escritura". - Alpha, 2004, núm. 20 , 151-164.

53-53. Pic-Gillard, Christine - "De la double identité dans l'écriture: du bilinguisme oral à la bilittéralité au Paraguay". - Carav, 2003, núm. 81, 229-246.

53-54. Reyes Coria, Bllmaro - "Lengua y trabajo editorial. Corrección ayer y hoy". - Cambio lingüistico y normatividad, coords. F. Colombo Airoldi y M. A. Soler Arechalde (México, 2003), pp. 149-157.

53-55. WRIGHT, R. - El tratado de Cabreros (1206): estudio sociofilológico de una reforma ortográfica (N. 50-205). II Incipit, 22 (2002), 216-219 (Kalinowki).

$\mathrm{V}$. también núm. 270.

\section{FONÉTICA Y FONOLOGÍA}

53-56. Betancolrt Arango, Amanda y Carlos García Zapata — "Caracterización fonética de dos zonas auríferas en Antioquia, Colombia". - BICC, 53 (1998), 1-59.
53-57. Calderón Rrvera, Álvaro - "Formulación algebraica para calcular la intensidad sonora acumulada". BICC, 53 (1998), 560-567.

53-58. García Riverón, RaQcel - Aspectos de la entonación hispánica. T. 1: Metodologia. - Universidad de Extremadura, Madrid, 1996. 168 pp. II BICC, 53 (1998), 175-177 (Montes Giraldo). 53-59. GLitart, Jorge M. - Sonido y sentido. Teoria y práctica de la pronunciación del español contemporáneo con audio $C D$. - Georgetown University Press, Washington, DC, 2004. 322 pp. + CD 53-60. Hernández-Caypoy, Jlay Manlel - "Functional compensation and southern peninsular Spanish /s/ loss". - Folia, 23 (2002), 31-57.

53-61. Kotschi, T., W. Osterreicher y K. Zimmermaniv (eds.) - El español hablado y la cultura oral en España e Hispanoamérica (N. 48-189). II BICC, 53 (1998), 159-171 (Montes Giraldo). 53-62. LOPE Blanch, Jlan M. (dir.) Atlas lingüistico de México. T. 1: Fonética. Vols. 1 y 2. - El Colegio de México-UNAM, México, 1990-92. II BICC, 53 (1998), 118-123 (Espejo Olaya). 53-63. MÁs, Sinbaldo dE - Sistema musical de la lengua castellana. Ed. de José Domínguez Caparrós. - CSIC, Madrid, 2001. 190 pp. II RLit, 64 (2002), 254-255 (Iriarte).

53-64. OPERSTEIN, NATALIE - "Late africation of $/ \mathrm{c} /$ and $/ \mathrm{z} /$ : Evidence from Spanish loans in zapotec and trigue". - RNo, 43 (2003), 147-151.

53-65. Rutz-SÁnchez, CaRMex - "El comportamiento de la /s/implosiva en el habla de Caracas". - BLin, 2004, núm. 21, 48-65.

53-66. Toledo, Guillermo - "Modelo autosegmental y entonación: una muestra del corpus CREA". - RFLI, 22 (2004), 313-327.

V. también núms. 98, 228, 295.

\section{MORFOLOGÍA Y SINTAXIS}

53-67. Arfonso Vega, Milagros - "La construcción activa impersonal en español: origen y actualidad". - $A L M$, 40 (2002), 267-291. 
53-68. Barme, Stefan - "Galicisch-Brasilianisch-lateinamerikanisches Spanisch: Konvergenzen in der Morphosyntax". - ZRPh, 119 (2003), ว78-596.

53-69. Batsilkova, Volhi — "Verbos de movimiento en ruso y español: una vez más sobre la intransitividad dividida". - Estudios de lingüística: el verbo, coords. J. L. Cifuentes Honrubia y C. Marimón Llorca (Alicante, 2004), pp. 11-42.

53-70. Beniers JaCob, Ei.isabeth - "Algunas observaciones sobre creación léxica en el español de México". Disquisiciones sobre filologia hispánica. In memoriam Juan $M$. Lope Blanch (México, 2004), pp. 65-71.

53-71. Bermúdez, FerNàdo - "Llegando a la conclusión: la escena del camino en los conectores consecutivos". RRo, 38 (2003), 239-271.

53-72. Bogard Sierra, Sergio - "La estructura de la cláusula. Hacia una metodología de análisis sintáctico". - Disquisiciones sobre filología hispánica. In memoriam Juan M. Lope Blanch (México, 2004), pp. 73-80.

53-73. BRLXNE, JACQLES - "Complementos esdrujuloides". - AEF, 26 (2003), 79-101.

53-74. Castañed Castro, Aifjandro "Una visión cognitiva del sistema temporal y modal del verbo en español". - Estudios de lingüistica: el verbo, coords. J. L. Cifuentes Honrubia y C. Marimón Llorca (Alicante, 2004), pp. 55-71.

53-75. Ciflentes Honrdbia, J. L. - Sintaxis y semántica del movimiento. Aspectos de gramática cognitiva (N. 47-1342). II RLiR, 67 (2003), 574-576 (Lengert). —V. núm. 51-183.

53-76. Ciflevtes Honkebia, José Luis "Verbos locales estativos en español". - Estudios de lingüistica: el verbo, coords. J. L. Cifuentes Honrubia y C. Marimón Llorca (Alicante, 2004), pp. 73-118.

53-77. Ciflextes Honrlbia, José Llis y Carmex Marimóx Llorca (coords.) Estudios de lingüistica: el verbo. - Universidad, Alicante, 2004. $628 \mathrm{pp}$.

53-78. Colombo Airoldi, Fluita - "So- bre el uso del perfecto en el espanol". - Disquisiciones sobre filología hispánica. In memoriam Juan M. Lope Blanch (México, 2004), pp. 85-94. 53-79. Colombo, Fulvia y Maria Áigeles SOLER - "Errores morfosintácticos en el español escrito?". - Cambio lingüistico y normatividad, coords. F. Colombo Airoldi y M. A. Soler Arechalde (México, 2003), pp. 171-178.

53-80. CoMpany CoMpany, Concepción "Gramaticalización por subjetivización como prescindibilidad de la sintaxis". - NRFH, 52 (2004), 1-27.

53-81. DeMello, George - "Supresión del pronombre clítico reflexivo". ALM, 40 (2002), 133-157.

53-82. Devís Márqlez, P. PABio - "La impersonalidad y las denominadas construcciones impersonales en español". - ZRPh, 119 (2003), 393-442.

53-83. Esparza Torres, Miglel Ángel "Sobre el análisis y clasificación de las operaciones de conectividad en español". - RGG, 10 (2004), 217-231.

53-84. FreNk, Margit - "Algunos estudios gramaticales de Lope Blanch". - Disquisiciones sobre filología hispánica. In memoriam Juan M. Lope Blanch (México, 2004), pp. 95-98.

53-85. Giola, Michele de \& Dolors Cataİ - "Étude comparée d'adverbes figés du français, de l'italien et de l'espagnol". - SemináriosL, 2004, núm. 5, 17-44.

53-86. Gralmann, Andrea - "Dynamic and static patterns in language: Instrumental verbs unfolded". - Estudios de lingüistica: el verbo, coords. J. L. Cifuentes Honrubia y C. Marimón Llorca (Alicante, 2004), pp. 233-243.

53-87. Gltiérrez-Rexach, J. y L. Silva-ViLLAR (eds.) - Current issues in Spanish syntax and semantics (N. 51-6). II RF, 115 (2003), 491-494 (Subirats-Rüggeberg).

53-88. Havfrkate, H. - The syntax, semantics and pragmatics of Spanish mood (N. ว1-74). \| RRo, 39 (2004), 342-344 (Lindschouw), - V. núm. 52-1642. 53-89. Herrerd, Alonso de - Sobre la persona gramatical. Ed., trad., índices y comentario de Antonio Ruiz Castellanos. - Universidad-Diputación de 
Toledo, Cádiz, 2002. ॥' $R G G, 39$ (2004), 91-92 (Niederehe).

53-90. Herrera Lima, María Elugenia "Los nexos adverbiales en las hablas culta y popular: una aproximación a los planteamientos teóricos y metodológicos de Lope Blanch". - Disquisiciones sobre filología hispánica. In memoriam Juan $M$. Lope Blanch (México, 2004), pp. 99-111.

53-91. Helk, Aafke \& Jean-Yves Pollock (eds.) - Subject inversion in Romance and the theory of universal grammar. Oxford University Press, New York, 2001. II $L, 39$ (2003), 211-213 (Suñer).

53-92. Hummel, M. - Adverbale und adverbialisierte Adjektive im Spanischen. Konstruktionen des Typs "Los niños duermen tranquilos" und "Maria corre rápido" (N. 51-76). II RF, 115 (2002), 360-363 (Gil). - V. núm. 52-62.

53-93. Jonge, BoB DE - "La oposición de los tiempos simples del pasado en relación con eventos bajo foco vs. eventos de soporte en algunas lenguas romances". - BLin, 2003, núm. 20, 43-55.

53-94. LAVRic, Eva - "Español tal, italian tale: de la anáfora cualitativa a la anáfora referencial". - RLiR, 67 (2003), 179-206.

53-95. Le Men Loyer, Jeanick - Gramática del español correcto. T. 1. - Universidad, León, 2003. 278 pp. II EHF, 26 (2004), 362-364 (Marcos Casquero).

53-96. Leonetti, Manuel - "Specificity and differential object marking in Spanish". - CatJL, 2004, núm. 3, 75114.

53-97. Luquet, Gilles - La teoría de los modos en la descripción del verbo español. (Un nuevo planteamiento). - Arco/Libros, Madrid, 2004. 213 pp.

53-98. Martín Camacho, Josê Carlos El problema lingüistico de los interfijos españoles. - Universidad de Extremadura, Cáceres, 2002. 266 pp. II VR, 62 (2003), 351-355 (Serrano-Dolader).

53-99. Martínez Linares, M. Antonia "En torno a los predicativos descriptivos del sujeto y los "estados" como predicados primarios". - Estudios de lingüistica: el verbo, coords. J. L. Cifuentes Honrubia y C. Marimón
Llorca (Alicante, 2004), pp. 331-362. 53-100. Martínez P., María Elgenia "La función orientadora de las frases nominales con rol gramatical locativo". - BLin, 2003, núm. 19, 43-55. 53-101. Materd, Masiel y Raimcndo Medi$\mathrm{NA}$ - "Los posesivos en la frase determinante en español". - BLin, 2003, núm. 19, 56-70.

53-102. MCNALly, Lotise - "Bare plurals in Spanish are interpreted as properties". - CatJL, 2004, núm. 3, 115-133.

53-103. Mensching, Guido - Infinitive constructions with specified subjects: A syntactic analysis of the Romance languages. - Oxford University Press, Oxford, 2000. 267 pp. II $J L, 38$ (2002), 447-448 (Cecchetto).

53-104. Montes Giraldo, José JoaQuín "Otra incursión en los compuestos nominales con infijo $-i-" .-B I C C, 53$ (1998), 568-571.

53-105. Moreno de Alba, José G. "¿Puede ser imperfecto el pretérito perfecto?". - ALM, 40 (2002), 73-91.

53-106. Myre Jørgensen, AnnetTe - "La pseudocoordinación verbale en norvégien et en espagnol". - $R R o, 38$ (2003), 53-66.

53-107. NaVArRo, José M. - "Verbos modales y modalidad: criterios funcionales en el proceso comunicativo". Estudios de lingüistica: el verbo, coords. J. L. Cifuentes Honrubia y C. Marimón Llorca (Alicante, 2004), pp. 443-450.

53-108. NowIKOW, WIACZESLAW - La alternancia de los modos indicativo y subjuntivo en las clásulas subordinadas sustantivas. - Uniwersytetulm. Adama Mickiewiczaw Poznaniu, Poznan, 2001. 157 pp. II BLin, 2003, núm. 19, 97-103 (Serrano y Vera).

53-109. OJeda, Elmerindo E. - "Functional entities -and that ain't the half of it!". - CatJL, 2004, núm. 3, 135-146.

53-110. Peñalver Castillo, Manuel "Sobre las oraciones consecutivas en español". - ALM, 40 (2002), 43-72.

53-111. Pérez Saldanya, Manuel - "La gramaticalización del verbo ir en construcciones narrativas del español". — Medievalia, 2003, núm. 35, 62-89. 
53-112. Pharies, D. - Diccionario etimoló gico de los sufijos españoles y de otros elementos finales (N. 51-89). II VR, 62 (2003), 337-343 (Lengert).

53-113. Pineda, Luis e Ivá. Mrza - "Ln modelo para la perífrasis española y el sistema de pronombres clíticos en HPSG". - ELAp, 2003, núm. 38, 45-67.

53-114. QLaglia Arduno, María Llisa "La aportación de Juan M. Lope Blanch al estudio de la construcción verbo modal + verbo unipersonal". Disquisiciones sobre filologia hispánica. In memoriam Juan $M$. Lope Blanch (México, 2004), pp. 159-164.

53-115. Rodriglez Espiñeira, M. José Lecciones de sintaxis española. - Universidade, Santiago de Compostela, 2004. 206 pp. (Colección Lalia. Series Maior, 19).

53-116. Santamaría Pérez, Rafael - "La información gramatical en los diccionarios monolingües de aprendizaje: reflexiones a partir del verbo". - Estudios de lingüistica: el verbo, coords. J. L. Cifuentes Honrubia y C. Marimón Llorca (Alicante, 2004), pp. 559-580.

53-117. Santana Manero, Jcana - "Preposición + (artículo) + que relativo: análisis en la norma lingüística culta panhispánica”. - BLin, 2004, núm. 21, 66-91.

53-118. Serrano, María José - "Formalidad y funcionalidad en el análisis del indicativo y del subjuntivo en espanol". - $A L M, 40$ (2002), 93-132.

53-119. Soares da Silva, Augusto "Verbos y construcciones causativas analíticas en portugués y en español”. - Estudios de lingüistica: el verbo, coords. J. L. Cifuentes Honrubia y C. Marimón Llorca (Alicante, 2004), pp. 581-598.

53-120. Sornicola, Rosanna, Erich Poppe \& Ariel Shisha-Haievy (eds.) - Stability, variation and change of word-order patterns over time. - J. Benjamins, Amsterdam, 2000. xxxi + 323 pp. II $R F, 115$ (2003), 143-146 (Schönberger)

53-121. Soto ANdión, Xosé - "Aproximación al habla de la Pontevedra interior: morfología verbal". - RFilR, 20 (2003), 53-72.
53-122. Thiballt, A. - Perfecto simple y perfecto compuesto en español preclásico. Estudio de los perfectos de indicativo en "La Celestina", el "Teatro" de Encina y el "Diálogo de la lengua" (N. 5197). II ZRPh, 119 (2003), 556-561 (Ossenkop).

53-123. Toledo y Huerta, Álvaro S. OCTAVIO DE - "Dos caminos sobre un mismo trazado. A propósito de la gramaticalización de dar tiempo y nuevamente". - Medievalia, 2003, núm. 35 , 90-134

53-124. TorNel Sala, José Luis - "Gramaticalización y cognición: perífrasis verbo-nominales". - ALHis, 17/18 (2001-02), 221-255.

53-125. Trives, Estanislao Ramón "Fundamentos noemáticos causativos y estativos entrañados en los esquemas cognitivos de determinados verbos dinámicos”. - Estudios de lingüistica: el verbo, coords. J. L. Cifuentes Honrubia y C. Marimón Llorca (Alicante, 2004), pp. 503-513.

53-126. VÁzQuez RozAs, VICTORIA "Transitividad prototípica y uso". BLin, 2004, núm. 21, 92-115.

53-127. Veiga, Alexandre - "Cantaba y canté sobre una hipóteis temporal y alguna de sus repercusiones". - Estudios de lingüística: el verbo, coords. J. L. Cifuentes Honrubia y C. Marimón Llorca (Alicante, 2004), pp. 599-614. 53-128. Veyrat Rigat, Montserrat "Una clasificación perceptiva de la categoría verbo". - Estudios de lingüistica: el verbo, coords. J. L. Cifuentes Honrubia y C. Marimón Llorca (Alicante, 2004), pp. 615-628.

V. también núms. 136, 165, 167, 169, $186,207,216,219,223,224,228,231$, 238-240, 244, 257, 265, 314, 358, 911.

\section{LEXICOLOGÍA Y LEXICOGRAFÍA}

53-129. Albano, Hilda, Adalberto Ghio, Mirta Stern y Beatriz Hall - "Algunas dificultades léxicas en alumnos universitarios ingresantes". - ALHis, $17 / 18$ (2001-02), 89-110.

53-130. Barme, Stefan - "Zur etymologie von sp. /pg moza / moça und rot- 
welsch / lëtzebuergesch $\dot{M} o \beta$ / Mosse(e)". - RGG, 39 (2004), 83-90.

53-131. Becerra Basclíáx, S. - Diccionario del uso de los casos en el español de Chile (N. 47-1450). II RRo, 36 (2001), 151-155 (Falk). - V. núm. 51-1883.

53-132. Becerra Pérez, Miglel - "La constitución del léxico extremeño (según se muestra en el habla popular del Almendralejo)". - $A E F, 26$ (2003), 13-29.

53-133. Bergla Cavero, Jorge - Los helenismos del español. Historia y sistema. Gredos, Madrid, 2004. 295 pp. (BRH. III. Manuales, 83).

53-134. Carriscondo Esoivel, Francisco M. - "El Vocabulario andaluz (1951), fuente de los andalucismos del DRAE (1970)". - NRFH, 52 (2004), 107-142.

53-135. Casanovas Catalá, Montserrat - "Sobre la interferencia léxica: patrones léxicos en el uso de una segunda lengua". - RFLL, 22 (2004), 25-36.

53-136. Delbecque, Nicole - "Verbos de respuesta: análisis léxico-construccional". - Estudios de lingüistica: el verbo, coords. J. L. Cifuentes Honrubia y C. Marimón Llorca (Alicante, 2004), pp. 119-165.

53-137. Frago Gracia, Aitonio - "Alari$f e$, un americanismo léxico entre la tradición y la innovación”. - RFE, 83 (2003), 291-298.

53-138. Fresnillo Nú̃̃ez, Javier y Antoni Biosca i Bas - "Propuesta para la elaboración de una concordancia lematizada: la Institvtio oratoria de Quintiliano". - Estudios de lingüística: el verbo, coords. J. L. Cifuentes Honrubia y $\mathrm{C}$. Marimón Llorca (Alicante, 2004), pp. 207-214.

53-139. García Medall, JoAQuíx - "Notas de lexicografia hispano-filipina. El $B o-$ cabulario de lengua bisaya, hiligueyna y haraya de la Isla de panay y Sugbu y para las demás islas, de fray Alonso de Méntrida, OSA (ca. 1637)". - Missionary linguistics/Lingüistica misionera. Selected papers from the First International Conference on Missionary Linguistics, Oslo, 13-16 March 2003, eds. O. Zwartjes \& E. Hovdhaugen (Amsterdam-Philadelphia, 2004), pp. 201-232.
53-140. García Sáichez, Jairo Javitr "Ocaña, Nambroca, Recas y otros nombres de lugar ¿repoblación vascófona en Toledo?". - RFE, 83 (2003), 145160.

53-141. Geckeler, Horst - "Convergencias europeas en el léxico español". - Historia del léxico español. Enfoques y aplicaciones. Homenaje a Bodo Müller, eds. J. Lüdtke y C. Schmitt (Frankfurt/M.-Madrid, 2004), pp. 183-195.

53-142. Gelblkh, AlexAidder y Grigori SIDOROv - "Hacia la verificación de diccionarios explicativos asistidos por computadora". - ELAp, 2003, núm. 38, 89-108.

53-143. Gómez Pablos, Beatriz - "Rafael Bluteau en el Diccionario de Autoridades". - RFLL, 22 (2004), 67-78.

53-144. HaENsCH, G. - Los diccionarios del español en el umbral del siglo XXI (N. 461490). II BICC, 54 (1999), 669-673 (Cruz Espejo). - V. núm. 49-181.

53-145. Heizle-Drehwald, Bernhard "El gitanismo en el argot español". Historia del léxico español. Enfoques y aplicaciones. Homenaje a Bodo Müller, eds. J. Lüdtke y C. Schmitt (Frankfurt/M.-Madrid, 2004), pp. 151-166.

53-146. Hett Chalvet, Devise - "La importancia del léxico indígena en la obra de Juan M. Lope Blanch. (Una aportación etimológica)". - Disquisiciones sobre filología hispánica. In memoriam Juan $M$. Lope Blanch (México, 2004), pp. 113-118.

53-147. LARA, LCis FerNando - "Culturas nacionales y léxico contemporáneo del español". - Historia del léxico español. Enfoques y aplicaciones. Homenaje a Bodo Müller, eds. J. Lüdtke y C. Schmitt (Frankfurt/M.-Madrid, 2004), pp. 303-315.

53-148. Martínez EgIDO, José JoAQuín "Presencia y desarrollo del verbo en el inicio de la lexicografía del español". - Estudios de lingüistica: el verbo, coords. J. L. Cifuentes Honrubia y C. Marimón Llorca (Alicante, 2004), pp. 315-330.

53-149. Montes Giraldo, José Joaqlín "Algo más sobre envolatar(se) y el DRAE 2001". - ZRPh, 119 (2003), 323-324. 
53-150. Noli, Volker - "El origen de esp. criollo, port. crioulo". - Historia del léxico español. Enfoques y aplicaciones. Homenaje a Bodo Müller, eds. J. Lüdtke y C. Schmitt (Frankfurt/M.Madrid, 2004), pp. 257-264.

53-151. Oscia Garcia, Francisco — "Los nombres propios: ¿lexemas o morfemas?". - RFE, 83 (2003), 93-132.

53-152. Peñalver Castillo, Manlel "Sobre sery estar". - AEF, 26 (2003), 299-317.

53-153. PÖli., BerNhard - Spanische lexikologie. - Narr, Tübingen, 2002. 169 pp. II VR, 62 (2003), 345-349 (Lukoschek).

53-154. PRIDE, JoHN - NTC's Dictionary of common mistakes in Spanish. - Lincolnwood, Illinois, 1996. 248 pp. II $B I C C, 54$ (1999), 667-669 (Viera).

53-155. Rfynoso, JeaNett - "La influencia del sustrato en el español mexicano: la postura de Juan M. Lope Blanch". - Disquisiciones sobre filologia hispánica. In memoriam Juan M. Lope Blanch (México, 2004), pp. 165-171.

53-156. Slaby, P. J., R. Grossman und C. ILLIG - Wörterbuch der spanischen und deutschen Sprache. B. 1: SpanischDeutsch (N. 49-198). II ZRPh, 119 (2003), 778-779 (Holtus). - V. núm. 52-1699.

53-15̄7. Soler Arechalde, María Ángeles - "Algunas cuestiones de lexicología en la obra del doctor Lope Blanch".

- Disquisiciones sobre filología hispánica. In memoriam Juan M. Lope Blanch (México, 2004), pp. 215-220.

53-158. Thiballt, André y Martin-D. Glessgen - "El tratamiento lexicográfico de los galicismos del español". - RLiR, 67 (2003), 5-53.

53-159. Thiballt, ANdré y Martiv-DieTRICH Glessgen - "Primera aproximación al tratamiento lexicográfico de los galicismos del español". - His. toria del léxico español. Enfoques y aplicaciones. Homenaje a Bodo Müller, eds. J. Lüdtke y C. Schmitt (Frankfurt/M.Madrid, 2004), pp. 197-215.

53-160. Torres Montes, Francisco - "Fitónimos amerindios recogidos por José Celestino Mutis". - BICC, 53 (1998), 242-270.

53-161. Vega, Pedro - "Descripción lé- xica del término coste de producción". - Historia del léxico español. Enfoques y aplicaciones. Homenaje a Bodo Müller, eds. J. Lüdtke y C. Schmitt (Frankfurt/M.-Madrid, 2004), pp. 233-255.

53-162. WEsCH, ANDrEas - "La expresión de la noción 'devenir' en español". - Historia del léxico español. Enfoques y aplicaciones. Homenaje a Bodo Müller, eds. J. Lüdtke y C. Schmitt (Frankfurt/M.-Madrid, 2004), pp. 217-232.

V. también núms. $70,112,116,166,170$ $190,203,204,221,226,229,234,241$, $243,245,250,255,270,337,360$, 1133.

\section{SEMÁNTICA}

53-163. Albai adejo Mayordomo, Tomás - "Elementos de la lengua literaria de la Edad de Oro: metáfora y alegoría como mecanismos de traslación". - Edad de Oro, 23 (2004), 33-39.

53-164. Castillo, Gabriel y Gerardo SieRRA - "Algoritmo flexibilizado de agrupamiento semántico". — ELAp, 2003, núm. 38, 69-80.

53-165. EsPinal, M. Teresa - "Lexicalization of light verb structures and the semantics of nouns". - CatJL, 2004, núm. 3, 15-43.

53-166. Fajardo González, Júan y Héctor JimÉNez SALAZAR - "Determinación de relaciones léxicas con base en el grado de subsunción". - ELAp, 2003, núm. 38, 81-87.

53-167. Farley, ANorew P. - "Semantic and syntactic perspectives on mood selection in Spanish: An analysis of presuposition, government, and binding". - ELAp, 2004, núm. 39, 13-35.

53-168. FogsgaARd, LeNe - Esquemas copulativos de "ser" y "estar". Ensayo de semiolingüistica. - P. Lang, Bern, 2000. 382 pp. II $R F, 115$ (2003), 536538 (Harris-Northall).

53-169. Hernádez Díaz, Axel - "La semántica locativa de las construcciones existenciales con haber. Un ejemplo de gramaticalización". Medievalia, 2003, núm. 35, 135-154. 53-170. Miglel, EleNa de - "Qué significan aspectualmente algunos verbos y 
qué pueden llegar a significar". - $E s$ tudios de lingüistica: el verbo, coords. J. L. Cifuentes Honrubia y C. Marimón Llorca (Alicante, 2004), pp. 167-206.

53-171. Montaner Montava, María AypaRO - "La importancia de lo cognitivo en la clasificación de los verbos del español". - Estudios de lingüistica: el verbo, coords. J. L. Cifuentes Honrubia y C. Marimón Llorca (Alicante, 2004), pp. 401-419.

53-172. Pérez Herranza, Fernando Miglel y Antonio López Crdces - "Sobre los verbos umbílicos de la semántica topológica". - Estudios de lingüistica: el verbo, coords. J. L. Cifuentes Honrubia y C. Marimón Llorca (Alicante, 2004), pp. 469-484.

V. también núms. 71, 74-76, 78, 83, 87, $88,93,94,97,99,100,102,105,107$, $108,118,124-126,911$.

\section{PRAGMÁTICA Y ANÁLISIS DEL DISGURSO}

53-173. Aglilar, César A. - "Análisis de frecuencia de construcciones anafóricas en narraciones infantiles". ELAp, 2003, núm. 38, 33-43.

53-174. Alarcón, Rodrigo y Gerardo SieRRA - "El rol de las predicaciones verbales en la extracción automática de conceptos". - ELAp, 2003, núm. $38,129-144$.

53-175. Blanco, J. José - "Diálogos en una novella del "Decamerón" castellano (siglo xv): alcances morfosintácticos". - Alpha, 2004, núm. 20, 243-263.

53-176. BRIz Gómez, A. - El español coloquial en la conversación. Esbozo de pragmagramática (N. 50-1621). II RFE, 83 (2003), 178-181 (Albelda Marco); BICC, 54 (1999), 321-325 (Cisneros Estupiñán).

53-177. Capanaga, Pilar - Salsa probiótica. La lengua de la publicidad alimentaria. - Libros Pórtico, Zaragoza, 2003. 193 pp. II I, 2003, núm. 57, 166168 (Pérez Vázquez).

53-178. Chumaceiro Arriaza, Irma - "El discurso de Hugo Chávez: Bolívar como estrategia para dividir a los venezo- lanos". - BLin, 2003, núm. 20, 22-42.

53-179. Chumaceiro, Irva - El estudio lingüistico del texto literario. Análisis de cuatro relatos venezolanos. - Universidad Central de Venezuela, Caracas, 2001. 216 pp. II BLin, 2003, núm. 20 , 56-60 (D'Aquino).

53-180. Doyle D'Ambrosio, Hope "Pragmática, sociolingüística y pedagogía de los pronombres de tratamiento en lengua española". ELAp, 2004, núm. 39, 37-52.

53-181. Ferrer, María Cristina y Carmen SÁNCHEZ LANZA - Interacción verbal: los actos de habla. - Universidad Nacional de Rosario, Rosario, 2002. 218 pp. II Blin, 2003, núm. 19, 107-108 (Ortiz).

53-182. Galán Rodríguez, Carmen "«La ciencia en zapatillas»: análisis del discurso de divulgación científica". - AEF, 26 (2003), 137-156.

53-183. González Agular, M. Isabel "La utilización de las unidades fraseológicas en las viñetas de los periódicos españoles". - RFLL, 22 (2004), 79-94.

53-184. Hernández Rojas, Gerardo "Las exposiciones de los alumnos en clase: un análisis desde el discurso expositivo experto". - ELAp, 2004, núm. 39, 107-132.

53-185. Jurado Salinas, Martha - "Hacia el desarrollo de una competencia binormativa". - Cambio lingüistico y normatividad, coords. F. Colombo Airoldi y M. A. Soler Arechalde (México, 2003), pp. 139-148.

53-186. Marimón Llorca, Carmen - "Argumentos verbales y organización textual: la dimensión discursiva del verbo". - Estudios de lingüistica: el ver$b o$, coords. J. L. Cifuentes Honrubia y C. Marimón Llorca (Alicante, 2004), pp. 267-287.

53-187. Molero de Cabeza, Lourdes y Julín CABEZA - "Secuencias y organización discursiva en textos del sistema educativo venezolano". BLin, 2004, núm. 21, 27-47.

53-188. Padilla García, Xose A. - "Y al principio... no fue el verbo (estrategias pragmáticas relacionadas con la posición del sujeto en la conversa- 
ción coloquial)". - Estudios de lingüistica: el verbo, coords. J. L. Cifuentes Honrubia y C. Marimón Llorca (Alicante, 2004), pp. 451-467.

53-189. Palacios Sierra, Margarita "Aportaciones al análisis gramatical del discurso (zonas de frontera)". Disquisiciones sobre filología hispánica. In memoriam Juan $M$. Lope Blanch (México, 2004), pp. 153-158.

53-190. Pozzi, María - "Hacia la armonización de la terminología usada en las normas del comité técnico ISO/ TC37: identificación semi-automática de términos problemáticos en un corpus". - ELAp, 2003, núm. 38, 109-127.

53-191. Reyes, Graciela - Metapragmática. Lenguaje sobre lenguaje, ficciones, figuras. - Universidad, Valladolid, 2002. 116 pp. II ALHis, 17/18 (200102), 293-296 (del Barrio).

53-192. Rivero D'Armas, Isabel - "La cortesía negativa en la entrevista investigativa". - BLin, 2003, núm. 19, 71-88.

53-193. Rodríglez Glerra, Ffrnando "La ejemplificación y la estructura de la cláusula en Buenos Aires". - Disquisiciones sobre filología hispánica. In memoriam Juan M. Lope Blanch (México, 2004), pp. 173-177.

53-194. Rosal Vargas, Gerardo Dei. "I La gestión de apreciaciones en las interacciones políticas". - EIA $p$, 2004, núm. 39, 133-153.

53-195. Serraio Dezi, Ricardo - Manual de análisis infoasistido de textos. Aplicado al teatro de los Siglos de Oro. Acompañado del programa multiplataforma brocense. - UNED, Madrid, 2001. 178 pp. II RCEH, 27 (2003), 393-395 (Deffis de Calvo).

53-196. Vivero Gikcía, María Dolores El texto: teoría y análisis lingüistico. Arrecife, Madrid, 2001. 317 pp. II RRo, 39 (2004), 334-336 (Pons Bordería).

V. también núms. 24, 38, 43, 88, 93, 107, $118,125,138,163,171,239,281,291$, 1037 .

\section{LATÍN Y LINGÜÍSTICA ROMÁNICA}

53-197. Ali.jères, Jacques - Manuel de linguistique romane. - Honoré Champion, Paris, 2000.323 pp. II RRo, 38 (2003), 163-164 (Boysen).

53-198. BLANK, A. - Einführung in die lexikalische Semantik für Romanisten (N. 52-1745). II $R F, 115$ (2003), 71-72 (Klein).

53-199. Calvo Fernádoez, V. - Grammatica Proverbiandi. Estudios de la Gramática Latina en la Baja Edad Media española (N. 49-55). II ZRPh, 119 (2003), 779-780 (Kramer). - V. núm. 51-1842.

53-200. Dworkin, Stevex N. \& Dieter W ANNER (eds.) - New approaches to old problems: Issues in Romance historical linguistics. - J. Benjamins, Amsterdam-Philadelphia, 2000. xiv +235 pp. II RLiR, 67 (2003), 538-540 (Lengert); Folia, 23 (2002), 169-172 (Nkollo).

53-201. Frings, Michael - "Zur Stellung romanischer Sprachen an Deutschlands allgemeinbildenden Schulen". - RGG, 10 (2004), 169-184.

53-202. Hassler, Gerda \& Hans-Josef Niederehe (eds.) - Geschichte des Sprachbewußtseins in romanischen Ländern. - Nodus, Münster, 2000. 272 pp. (Studium Sprachwissenschaft, 33). II $R F, 115$ (2003), 262-263 (Aschönberger); ZRPh, 119 (2003), 673-683 (Lieber).

53-203. Holtes, Génter, Mrchael MetzFitin \& Ciyristian Schmitt (Hg.) Lexikon der Romanistischen Linguistik. T. 1.1: Geschichte des Faches Romanistik. Methodologie (Das Sprachsystem). Niemeyer, Tübingen, 2001.1 + 1053 II $R F, 115$ (2003), 74-80 (Rainer).

53-204. Holtus, Gejter, Michael Metzel.tix \& Christiax Schymt ( $\mathrm{Hg}$.) Lexikon der Romanistischen Linguistik. T. 1.2: Methodologie. (Sprache in der Gesellsxhaft/Sprache und Klassifikation/ Datensammlung und-verarbeitung). Niemeyer, Tübingen, 2001. xlv + 1194 pp. II RF, 115 (2002), 241-244 (Rainer).

53-205. Ki Al SEXBLRgFr, J. - Grammaticalization. Studies in Latin and Romance 
morphosintax (N. 52-189). ॥ RLiR, 67 (2003), 547-549 (Lengert).

53-206. Kualsexblrger, JC̈rgeN - Coursebook in Romance linguistics. - Lincom Europa, München, 2001. 203 pp. II $R F, 115$ (2003), 245-247 (Sánchez Miret).

53-207. Lamiroy, Béatrice - "La teoría de la gramaticalización y sus aplicaciones en las lenguas románicas". Estudios de lingüística: el verbo, coords. J. L. Cifuentes Honrubia y C. Marimón Llorca (Alicante, 2004), pp. 245-266.

53-208. LALRENT, R. - Past participles from Latin to Romance (N. 51-250). II $R F$, 115 (2003), 91-99 (Lengert). - V. núm. ว1-1848.

53-209. Levine Melammed, Renéf - "Ladino speaking women of the $20^{\text {th }}$ century". - Studies in honor of Denah Lida, eds. M. G. Berg \& Lanin A. Gyurko (Potomac, Maryland, 2005), pp. 391-402.

53-210. Mesa Sanz, Juan F. - "Participio de presente latino tardío y medieval: entre norma y habla". - Estudios de lingüistica: el verbo, coords. J. L. Cifuentes Honrubia y C. Marimón Llorca (Alicante, 2004), 363-379.

53-211. MonfRIN, Jacules - Études de philologie romane. - Droz, Genève, 2001. $\mathrm{xi}+1035$ pp. II VR, 62 (2003), 265266 (Gresti); ZRPh, 119 (2003), 621623 (Heijkant).

53-212. Pöckl, Wolfgang, Franz Rainer \& Bernhard PölL - Einführung in die romanische Sprachwissenschaft. - Max Niemeyer, Tübingen, 2003. 198 pp. 53-213. SAi A, M. - De la latinâ a la româna (N. 50-1645). II BICC, 53 (1998), 666-669 (Montes Giraldo). - V. núm. 52-1752.

53-214. SAlA, M. - Du latin au romain (N. 49-71). II RRo, 36 (2001), 297-299 (Price). - V. núm. 52-194.

53-215. SAMPSON, RODNEY - Nasal vowel evolution in Romance. - Oxford University Press, Oxford, 1999. xv + 413 pp. II $/ L$, 38 (2002), 229-235 (Absalom); $R F, 115$ (2003), 413-416 (Gather).

53-216. TAsmowsk, Liliave - "Existe-t-il un paradigme du pronom personnel dans les langues romanes?". - $R F$,
115 (2003), 149-170.

53-217. Vañó-Cerdá, Antonio - "Esser y star con predicados nominales en retorrománico". - RLiR, 67 (2003), 463-497.

V. también núms. 91, 94, 103, 246.

\section{HISTORIA DE LA LENGUA ESPAÑOLA}

53-218. Arias Álvarez, Beatriz - "Las cartas de Diego de Ordaz: la primera aportación al estudio del español". Disquisiciones sobre filología hispánica. In memoriam Juan M. Lope Blanch (México, 2004), pp. 27-32.

53-219. Barraza Carbajal, Georgana "Estructura y evolución de la frase nominal de objeto directo inanimado en español". - Medievalia, 2003, núm. 35, 155-182.

53-220. Bustos Tovar, José Jesís de "Hablar y escribir en los albores del Siglo de Oro". - Edad de Oro, 23 (2004), 53-70.

53-221. Carbonell, Ignacio y Magdalena Cols - "El léxico de la alimentación en el siglo XviII en la Banda Oriental". - ALHis, 17/18 (2001-02), 51-73.

53-222. Coello Mesa, Avtonia María "Contribución al estudio del sistema preposicional en el castellano de la Edad Media". - RFLL, 22 (2004), 5565.

53-223. Compayy Company, Concepción "La gramaticalización en la historia del español". - Medievalia, 2003, núm. 35, 3-61.

53-224. Company Company, Concepción (ed.) - Gramaticalización y cambio sintáctico en la historia del español. UNAM, México, 2003. 208 pp. II $R G C, 10$ (2004), 239-242 (Niederehe).

53-225. Eberenz, R. - El español en el otono de la Edad Media. Sobre el artículo y los pronombres (N. 49-1755). $\| R F, 115$ (2003), 395-396 (Messner). - V. núm. 52-1758.

53-226. Eberex7., Rolf - "En torno al léxico fundamental del siglo $\mathrm{xv}$ : sobre algunos campos verbales". - Historia del léxico español. Enfoques y aplicaciones. Homenaje a Bodo Müller, eds. J. 
Lüdtke y C. Schmitt (Frankfurt/M.Madrid, 2004), pp. 111-136.

53-227. Fernández Corrai., Celia - "Términos romances en la documentación medieval del Reino de León (ss. VIII-XIII)". - ALHis, 17/18 (2001-02), $75-87$.

53-228. García Martín, José María - La formación de los tiempos compuestos del verbo en español medieval y clásico. Aspectos fonológicos, morfológicos y sintácticos. - Valencia, 2001. 175 pp. (Cuadernos de Filología, 47). II RFE, 83 (2003), 186-189 (Rodríguez Molina).

53-229. Gemmingen, Brarbara von "Consideraciones filológicas acerca de un léxico específico medieval: el Arte Cisoria de Enrique de Villena (1423)". - Historia del léxico español. Enfoques y aplicaciones. Homenaje a Bodo Müller, eds. J. Lüdtke y C. Schmitt (Frankfurt/M.-Madrid, 2004), pp. 89-110.

53-230. Gil Garcia, Teresa - " "...Italia todo es hablar, y España...". Apuntes para una historia de nuestras lenguas". - Criticón, 2003, núms. $87 / 88 / 89,347-357$.

53-231. Girón Alcoxchel, José Luis "Cambios sintácticos en el español de la Edad de Oro". - Edad de Oro, 23 (2004), 71-93.

53-232. González Monllor, Rosa María - "Algunos aspectos lingüísticos de la documentación notarial de Canarias del siglo Xv". - ALHis, 17/18 (2001-02), 129-144.

53-233. González Ollé, Fervando "Observaciones filológicas al códice emilianense 46 (Glosario Turza), con algunas de sus aportaciones a la historia lingüística española". - Historia del léxico español. Enfoques y aplicaciones. Homenaje a Bodo Müller, eds. J. Lüdtke y C. Schmitt (Frankfurt/M.Madrid, 2004), pp. 13-37.

53-234. Gütida, Eva-María - "Indio e indiano en el español anterior a 1400". - Historia del léxico español. Enfoques y aplicaciones. Homenaje a Bodo Müller, eds. J. Lüdtke y C. Schmitt (Frankfurt/M.-Madrid, 2004), pp. 73-87. 53-235. Hernáidez Heriández, José MA$\triangle \mathrm{LEL}$ - Cartas de medianeros de Tenerife
(1769-1893). - Academia Canaria de la Lengua, Islas Canarias, 2003. 227 pp. II RFLL, 22 (2004), 338-341 (Díaz Alayón).

53-236. Hervando García-Cervigón, AlberTO - "El adverbio en el Arte del romance castellano (1769) de Benito de San Pedro". - RFilR, 20 (2003), 41-51. 53-237. Hilty, Gerold - "Cinco notas ibero-románicas relacionadas con el Libro conplido". - VR, 62 (2003), 182193.

53-238. Hlerta Flores, Norohella "Gramaticalización del posesivo. Un proceso hacia la abstracción". - Medievalia, 2003, núm. 35, 183-197.

53-239. Јасов, D. у J. KaвATEK (eds.) Lengua medieval y tradiciones discursivas en la Península ibérica. Descripción gramatical-pragmática histórica-metodología (N. 49-1729). II ZRPh, 119 (2003), 698-706 (Böhmer). - V. núm. 52-1764.

53-240. López García, A. - Cómo surgió el español. Introducción a la sintaxis histórica del español antiguo (N. 47-76). II RFE, 83 (2003), 194-198 (García Sánchez). - V. núm. 52-1768.

53-241. Lüdtke, JENs — "Las perspectivas etnolingüísticas en el léxico novohispano del siglo xv". - Historia del léxico español. Enfoques y aplicaciones. Homenaje a Bodo Müller, eds. J. Lüdtke y C. Schmitt (Frankfurt/M.-Madrid, 2004), pp. 285-302.

53-242. Mosteiro Louzao, M. - Las conjunciones de causa en castellano medieval. Origen, evolución y otros usos (N. 50-202). II ALM, 40 (2002), 413-417 (Alfonso Vega). - V. núm. 51-295. 53-243. Múıler, Bodo - "Aspectos del léxico medieval desde la perspectiva del Diccionario del español medieval (DEM)". - Historia del léxico español. Enfoques y aplicaciones. Homenaje a Bodo Müller, eds. J. Lüdtke y C. Schmitt (Frankfurt/M.-Madrid, 2004), pp. 61-71.

53-244. Ramírez Luevgo, José Llis - "El pretérito de subjuntivo en la Venezuela de la Independencia: alternancia $-r a /-s e$ en el epistolario de Bolívar". - ALHis, 17/18 (2001-02), 257-272. 
53-245. SaYers, Wili.iam - "Swagger and Sashay: An etymology for Spanish majo/maja". — RNo, 44 (2004), 293-298.

53-246. Schäfer-Priess, Barbara, HildeGaRd Klöden \& Rolf KailuteIt (eds.) - Grammatikalisierung in den iberoromanischen Sprachen. - Gottfried Egert, Wilhelmsfeld, 2001. 217 pp. II I, 2003, núm. 57, 157-163 (Kretz); VR, 62 (2003), 334-337 (Schor).

53-247. Schmidt-Riese, Roi.ANd - Reflexive Oberflächen im Spanischen. "Se" in standardfernen Texten des 16. Jarhunderts. - Narr, Tübingen, 1998. 244 pp. (Romanica Monacensia, 55). II RF, 115 (2003), 99-101 (Schönberger).

53-248. Serradilla Castaño, Ana - "Superlativos cultos y populares en el español clásico". - Edad de Oro, 23 (2004), 95-133.

53-249. Sosa, Obediente - Biografia de una lengua. Nacimiento, desarrollo y expansión del español. - Libro Universitario Regional, Cartago (Costa Rica), 2000. 554 pp. II ALHis, 17/18 (200102), 283-285 (Carrera de la Red).

53-250. STORK, YvONXE - "La historia del léxico hispánico y la noción de economía”. - Historia del léxico español. Enfoques y aplicaciones. Homenaje a Bodo Müller, eds. J. Lüdtke y C. Schmitt (Frankfurt/M.-Madrid, 2004), pp. 167-181.

53-251. Torrens Álvarez, M. J. - Edición y estudio lingüistico del "Fuero de Alcalá" (Fuero Viejo) (N. 51-300). $\|$ RLiR, 67 (2003), 595-598 (Eberenz).

V. también núms. $41,67,80,111,123$, $124,150,155,165,175,200,335,865$.

\section{DIALECTOLOGÍA Y GEOLINGÜÍSTICA}

53-252. Alvar, Mancel - El español en Venezuela. Estudios, mapas, textos. Ed. de Antonio Alvar Florentino Paredes. Universidad de Alcalá-La Goleta-AECI, Madrid, 2001. 3 ts \| RFE, 83 (2003), 173-177 (Campillo García). 53-253. Alvar, M. (dir.) - Manual de dialectología hispánica. (Fl español de América) (N. 48-1889). II BICC, 53 (1998), 383-386 (Lozano Ramírez). —V. núm. 51-1880.
53-254. Alvar, Mancel (dir.) - Manual de dialectología hispánica. (El español de España). - Ariel, Barcelona, 1996. 394 pp. II BICC, 53 (1998), 387-390 (Lozano Ramírez).

53-255. ARAQCE, ADRLANA A. - "Pervivencia de elementos léxicos de origen africano en registros coloquiales en la comarca Viedma Carmen de Patagones". - ALHis, 17/18 (2001-02), 179-191.

53-256. Arjona Iglesias, Marina - "El habla popular: una idea visionaria del doctor Lope". - Disquisiciones sobre filologia hispánica. In memoriam Juan M. Lo pe Blanch (México, 2004), pp. 33-38.

53-257. Asratian, Artcia - "Oraciones coordinadas que representan eventos temporales en el español hablado en Caracas". - BLin, 2003, núm. 19, 3-19. 53-258. Barme, Stefan - "Zum (ibero-) romanischen Ursprung einiger (morpho-) syntaktischer Strukturen des Papiamentu und des español caribeño". - ZRPh, 119 (2003), 232-255.

53-259. Betancolrt, Amanda, Ángeia Osorio y Carlos García - Atlas lingüistico de Antioquia. - Universidad de Antioquia, Medellín, 1995. 490 pp. II BICC, 53 (1998), 146-151 (Aparicio Ramírez Caro).

53-260. Béz Pinal, Gloria Estela - "Vitalidad y tradición de hipocorísticos empleados en la ciudad de México: 1955-1999. Un estudio comparativo". - ALM, 40 (2002), 241-265.

53-261. BOLLER, F. - Die Isoglossenstaffelung in der galicisch-portugiesisch-spanischen Kontakzone und im Lombada-Aliste-Grenzgebeit. B. 1: Kommentar zum Regionalsprachtlas: Die diatopische Variation im Dialektraum. B. 2: Regionalsprachatlas mit synoptischem Kartenteil (N. 49-230). II ZRPh, 119 (2003), 608-613 (Regueira).

53-262. Caicedo, Maximiliano - Diferenciación dialectal en el español hablado en Buenaventura. - Gobernación del Valle del Cauca, Cali, 1996. II BICC, 53 (1998), 171-172 (Montes Giraldo). 53-263. Chl maceiro, IrMa e Irana MaLater - El español de América: Venezuela. Arco/Libros, Madrid, 1999. II BICC, 54 (1999), 674-675 (Lozano Ramírez). 53-264. D'AQuino Ruz, Giovaxisa "Haber impersonal en el habla de Ca- 
racas. Análisis sociolingüístico". BLin, 2004, núm. 21, 3-26.

53-265. Donni de Mirande, Nélida - "Aspectos del sistema verbal en Santa Fe (Argentina) en el siglo xix". - $A L$ His, 17/18 (2001-02), 145-164.

53-266. FernáNdez Juncal, C. - Variación léxica y variación social en el Valle de Aras, pról. J. Borrgo Nieto (N. 47-1455). II ALHis, 17/18 (2001-02), 297-299 (Zamora). - V. núm. 51-1939.

53-267. Fontanella de Weinierg, B. - El español de la Argentina y sus variedades regionales (N. 51-1897). II ALHis, 17/18 (2001-02), 279-282 (Virkel).

53-268. Frago Gracia, Jcan antonio y Marlano Franco figleroa - El español de América. 2a ed. corregida y aumentada. - Universidad, Cádiz, 2003. 302 pp. || BLin, 2004, núm. 21, 130-135 (de Stefano).

53-269. Hetzer, ARMIN - Sephardisch. Juedo-español, Djudezmo. Einführung in die Umgangssprache der südosteuropäschen Juden. - Harrassowitz, Wiesbaden, 2003. $\mathrm{x}+138$ pp. II ZRPh, 119 (2003), 194-196 (Kramer).

53-270. Hupperdinger, Yolanda - "Alternancia en la representación gráfica de los préstamos léxicos en el espanol bonaerense". - ALHis, 17/18 (2001-02), 165-177.

53-271. LIPSKI, JoHN M. - El español de América. - Cátedra, Madrid, 1996. 446 pp. II BICG, 53 (1998), 172-175 (Montes Giraldo).

53-272. López Chávez, Jual - "Lope Blanch: el Atlas de la dialectología mexicana". - Disquisiciones sobre filología hispánica. In memoriam Juan M. Lope Blanch (México, 2004), pp. 129-132.

53-273. MondÉJAR, JosÉ — Dialectología andaluza. Estudios: historia, fonética y fonología, lexicología, metodología, onomasiologia y comentario filológico. Ed. de Pilar Carrasco y Manuel Galeote. - Universidad, Málaga, 2001. 2 ts.: 692 pp. II VR, 62 (2003), 344-345 (Lengert).

53-274. Montes Giraldo, José Joaquín El español de América: Colombia. - Arco/Libros, Madrid, 1999. II BICC, 54 (1999), 674-675 (Lozano Ramírez). 53-275. Mort Moxroy, Siervo Custodio - "El habla popular boyacense. Aná- lisis lingüístico de un texto oral". BICC, 53 (1998), 217-241.

53-276. Mora Ochoa, Alejandro de la "La estandarización del español mexicano". - Cambio lingüistico y normatividad, coords. F. Colombo Airoldi y M. A. Soler Arechalde (México, 2003), pp. 97-108.

53-277. Narbona, A., R. Cano y R. MoriLLo - El español hablado en Andalucía (N. 49-1828). II BICC, 53 (1998), 670674 (Montes Giraldo).

53-278. Navarro, Manuel - "El uso del "que» galiciado en el habla de Valencia, Venezuela". - BICC, 53 (1998), 575-581.

53-279. Navarro Carrasco, A. I - Léxico de Estepona. Segín datos del ALEA y del LMP (N. 50-214). II NRFH, 52 (2004), p. 178 (Fernández Gordillo).

53-280. Quilis, A. y C. Casado-Fresnillo - La lengua española en Guinea Ecuatorial (N. 48-199). II BICC, 53 (1998), 144-146 (Montes Giraldo). - V. núm. 52-1809.

53-281. Ramírez Gelbes, Silvia y Andrea ESTRADA - "Vocativos insultivos vs. vocativos insultativos: acerca del caso de boludo". - AEF, 26 (2003), 335-353.

53-282. Salra Rami, José Antonio - "La transición lingüística en el Pirineo Central (III)". - RLiR, 67 (2003), 431-443.

53-283. VAQuero, María - "Hablas juveniles de Puerto Rico: ¿interferencias por contacto o cambios sistemáticos?". Íns, 2003, núms. 679/680, 33-37.

53-284. Vigueras Ávila, Alejandra "Juan M. Lope Blanch y el proyecto de la norma culta". — Disquisiciones sobre filologia hispánica. In memoriam Juan M. Lope Blanch (México, 2004), pp. 221-224.

V. también núms. $45,56,62,64-66,89$, $121,131,132,134,221,235,258,293$, 294, 297.

\section{SOCIOLINGÜÍSTICA}

53-285. Arlas y Aloyso, Magdalexa "La expresión de las relaciones de fraternidad en la diplomática medieval latina". - EHF, 26 (2004), 11-33. 
53-286. Bossong, G. y F. BÁez de Agullar GONzÁlez (eds.) - Identidades lingüisticas en la España autonómica (N. 491527). II NRFH, 52 (2004), 173-177 (Serrano Morales).

53-287. Briz, ANTonio - "Notas sobre los llamados usos temporales «dislocados» en la conversación coloquial". - Estudios de lingüística: el verbo, coords. J. L. Cifuentes Honrubia y C. Marimón Llorca (Alicante, 2004), pp. 45-53.

53-288. Calvo Salgado, Luís M. "Aprender a hablar, ¿un milagro para los sordos del siglo xvi?". - Criticón, 2003, núms. 87/88/89, 113-123.

53-289. Colombo Airoldi, Fulvia y María Ángeles Soler Arechalde (coords.) - Cambro lingüístico y normatividad. UNAM, México, 2003. 180 pp. (Publicaciones del Centro de Lingüística Hispánica, 49).

53-290. COMPANy CoMpany, Concepción “Qué es un cambio lingüístico?”. Cambio lingüistico y normatividad, coords. F. Colombo Airoldi y M. A. Soler Arechalde (México, 2003), pp. 13-32.

53-291. García Godoy, Maria Teresa "De Majestad a Señores diputados. La evolución de las fórmulas de tratamiento en los orígenes del parlamentarismo argentino (1810-1861)". ALHis, 17/18 (2001-02), 11-24.

53-292. Gilbert, GlenN (ed.) - Pidgin and creole linguistics in the twenty-first century. - P. Lang, New York, 2002. 379 pp. II ZRPh, 119 (2003), 689-697 (Bartens).

53-293. Lope Blanch, Juan M. - "La norma en lingüística". - Cambio lingüístico y normatividad, coords. F. Colombo Airoldi y M. A. Soler Arechalde (México, 2003), pp. 55-62.

53-294. Lope Blanch, Juan M. - "La norma lingüistica hispánica". - $A L M, 40$ (2002), 23-41.

53-295. Martin Butragueño, Pedro "Los mecanismos sociales del cambio lingüístico". - Cambio lingüístico y normatividad, coords. F. Colombo Airoldi y M. A. Soler Arechalde (México, 2003), pp. 33-52.

53-296. Martín Butragueño, Pedro -
Variación lingüistca y teoria fonológica. - El Colegio de México, México, 2002. 193 pp. II BLin, 2004, núm. 21, 126-129 (Obediente Sosa).

53-297. Montes de Oca Sicilia, Pilar -

"Las subnormas cultas y las creencias sobre ellas". - Cambio lingüistico y normatividad, coords. F. Colombo Airoldi y M. A. Soler Arechalde (México, 2003), pp. 159-167.

53-298. Moreno de Alba, José G. - "Corrección y conciencia lingüística”. Cambio lingüistico y normatividad, coords. F. Colombo Airoldi y M. A. Soler Arechalde (México, 2003), pp. 63-77.

53-299. Moreno Fernández, F. - Principios de sociolingüistica y sociología del lenguaje (N. 49-1884). II BICC, 53 (1998), 674-682 (Montes Giraldo). V. núm. 511-1947.

53-300. Rojas Nieto, Cecilia - "Orígenes del discurso normativo y su reproducción social". - Cambio lingüistico y normatividad, coords. F. Colombo Airoldi y M. A. Soler Arechalde (México, 2003), pp. 79-94.

53-301. SERRón, SERGIO - Introducción al estudio de la planificación lingüistica internacional. - UPEL-IPEMAR, Caracas-Maracay, 1993. 78 pp. II BICC, 53 (1998), 142-144 (Montes Giraldo). 53-302. Torres González, RoAmé "Idiomas, identidades lingüísticas y política partidista en Puerto Rico". ins, 2003, núms. 679/680, 25-32.

V. también núms. 44, 53, 89, 117, 176 , $180,185,188,192,264,266,283,307$, $309,310,341,1062$.

\section{EL ESPAÑOL EN CONTACTO CON OTRAS LENGUAS}

53-303. Bev-Ur, Avtva - "Embracing the Hispanic: Jews, Puerto Ricans, and Spaniards in immigrant New York (1880-1950)". - Studies in honor of Denah Lida, eds. M. G. Berg \& Lanin A. Gyurko (Potomac, Maryland, 2005), pp. 403-413.

53-304. Сummins, Јім - Lenguaje, poder y pedagogia. Niños y niñas bilingües entre dos fuegos. - Ediciones Morata-Minis- 
terio de Educación, Cultura y Deporte de España, Madrid, 2002. 351 pp. II SignosU, 2003, núm. 39, 270-271 (Larripa).

53-305. Granda, Germáx de - "Un proceso de transferencia bidireccional sucesiva en el área andina. Evidenciales reportativos entre quechua y español". - ALHis, 17/18 (2001-02), 193-201.

53-306. Hawayek, Antonette - "El español como segunda lengua. Descripción de algunas estructuras producidas por niños hablantes de tres lenguas indígenas". - SLL, 5 (2003), núm. 1, 143-160.

53-307. KaIluweit, R. - Vom eigenen Sprechen. Eine Geschichte der spanisch-katalanischen Diglossie in Katalonien (1759-1859) (N. 49-89). II ZRPh, 119 (2003), 188-191 (Brumme).

53-308. Lastra, Yolanda - "Que Dios l'acompañe, que Dios la cuide". Disquisiciones sobre filología hispánica. In memoriam Juan M. Lope Blanch (México, 2004), pp. 125-128.

53-309. Moraies, Amparo - "Desplazamientos y revitalización del español en los Estados Unidos: panorama general". — Íns, 2003, núms. 679/680, 2-8.

53-310. McNón Cruz, Héctor - "La modalidad guaranihablante o la improbable transición desde el bilingüismo social hasta el bilingüismo escolar en Paraguay". - SLL, 丂 (2003), núm. 1, 185-213.

53-311. Reyoso Noveró, Jfanert "Desarrollos paralelos en el contacto español-lenguas indígenas: indigenismos léxicos y diminutivos". - $A L$ His, 17/18 (2001-02), 111-128.

53-312. S.AL, M. - Lenguas en contacto (N. 46-1584). II BICC, 53 (1998), 669670 (Montes Giraldo). - V. núm. 51360 .

53-313. Siglá, M. - Bilingüismo y lenguas en contacto (N. 52-262). II RFilR, 20 (2003), 282-287 (Sáez Rivera). 一 V. núm. 52-1857.

53-314. Silva-Corvalix, CARMEX - "El español en Los Ángeles: aspectos morfosintácticos". - Ins, 2003, núms. $679 / 680,19-25$.
53-315. Zentella, Ana Celia - "Recuerdos de un nuyorican". - Ins, 2003, núms. 679/680, 37-40.

53-316. ZimmermanN, K. (ed.) - Lenguas en contacto en Hispanoamérica (N. 451604). II BICC, 54 (1999), 315-321 (Cisneros Estupiñán). - V. núm. 47 . 240.

V. también núms. 53, 145, 258, 269.

\section{ADQUISICIÓN DEL LENGUAJE Y PSICOLINGÜÍSTICA}

53-317. Barriga Villanueva, R. - Estudios sobre el habla infantil en los años escolares: "...un solecito calientote" (N. 50-1699). II BLin, 2003, núm. 19, 104 106 (Hernández Villaria); NRFH, 52 (2004), 179-182 (Montes Giraldo). V. núm. ว̌2-1863.

53-318. Lapegna, Mónica y Reina HimelFARB - "La adquisición del lenguaje según Chomsky y Piaget". - AIM, 40 (2002), 333-341.

53-319. Serra, Miguel, Elisabeth Serrat, Rosa Solé, Aurora Bel y Maina Apari$\mathrm{CI}$ - La adquisición del lenguaje. - Ariel, Barcelona, 2001. 665 pp. II BLin, 2003, núm. 20, 66-70 (Aveledo).

V. también núms. 184, 323.

\section{ENSEÑANZA DEL ESPAÑOL}

53-320. Barriga Villanueva, Rebeca "El deseo y la realidad. La enseñanza del español a los indígenas mexicanos". - Cambio lingüístico y normatividad, coords. F. Colombo Airoldi y M. A. Soler Arechalde (México, 2003), pp. 109-138.

53-321. Esch, Kees vax, Pifter de HaAn y MARLY NAS - "El desarrollo de la escritura en inglés y español como lenguas extranjeras". - ELAp, 2004, núm. 39, 53-79.

53-322. García, Offila - "La enseñanza del español a los latinos de los Estados Unidos: contra el viento del olvido y la marea del inglés". - Ins, 2003, núms. 679/680, 9-13.

53-323. LAFFORD, B. A. \& R. SALABERRY (eds.) - Spanish second language ac- 
quisition. State of the science (N. 521868). II ELAp, 2004, núm. 39, 157 165 (Peralta Estrada).

53-324. Luppino, Silvia - "La evaluación en un contexto diferente: los cursos de español para migrantes". - Signos $U, 2003$, núm. 39, 155-160.

53-325. Minervini, Rosaria - "La enseñanza del español para futuros traductores e intérpretes: ¿qué objetivos específicos debe proponerse el profesor de E/LE?". - AION-R, 45 (2003), 425-439.

53-326. Mosony, Esteban Emilio - "Estado actual de la enseñanza intercultural bilingüe". - BLin, 2004, núm. 21, 116-125.

53-327. Provencio Garrigós, Herminla "Aplicaciones de tecnología lingüística y otros recursos didácticos para la enseñanza/aprendizaje del español como lengua extranjera: el verbo". Estudios de lingüistica: el verbo, coords. J. L. Cifuentes Honrubia y C. Marimón Llorca (Alicante, 2004), pp. 485-502.

53-328. Roca MaríN, Santiago - "Problemas con el aspecto verbal en e/le". - Estudios de lingüistica: el ver$b o$, coords. J. L. Cifuentes Honrubia y C. Marimón Llorca (Alicante, 2004), pp. 515-528.

53-329. Sánchez Lobato, Jesés, Isabei. Santos Gargaildo y Raquel Pinilla GóMEZ - Asedio a la enseñanza del español como segunda lengua (L2)/lengua extranjera (LE). - SGEL, Madrid, 2003. II RFilR, 20 (2003), 287-292 (Cortés Parazuelos).

V. también núm. 306.

\section{TRADUCGIÓN}

53-330. Goyzílez Roláx, T., A. Moreno Hernández y P. Siqlero Slírez-SoMONTE - Humanismo y teoría de la traducción en España e Italia en la primera mitad del siglo X1: Edición y estudio de la "Controversia Alphonsina" (Alfonso de Cartagena vs. L. Bruni y P. Candido Decembrio). - Ediciones Clásicas, Madrid, 2000.457 pp. II RLit, 64 (2002), 259-260 (Algaba).
53-331. Lafarga, Francisco, Concepción Palacios y Alfonso Saura (eds.) Neoclásicos y románticos ante la traducción. - Universidad, Murcia, 2002. 450 pp. II RLit, 65 (2003), 305-307 (Medina Arjona).

53-332. LANERo, J. J. - "Una torre para alcanzar a Dios: el crítico como intérprete de los traductores bíblicos". EHF, 26 (2004), 101-114.

53-333. LunN, P. y E. LunNsford - En otras palabras. La traducción y el aprendizaje de un idioma en niveles avanzados (N. 52-1880). II ELAp, 2004, núm. 39, 167-168 (Jiménez Llamas).

53-334. Martines Peres, Vicent - "Loucions verbals i intel.lecció de classicas romanics medievals en les seues traduccions. Locucions i collocacions multilingües". - Estudios de lingüisti$c a$ : el verbo, coords. J. L. Cifuentes Honrubia y C. Marimón Llorca (Alicante, 2004), pp. 289-313.

53-335. Martínez Ortega, Ricardo "Observaciones sobre el léxico y la traducción de la crónica (Additiones a De rebus hispanie) de Benito Morer de Torla". - RFLL, 22 (2004), 153-161. 53-336. Martínez Romero, Tomás y Roxaì RECIO (eds.) - Essays on Medieval translation in the Iberian peninsula. - Universitat Jaume I-Creighton University, Castelló de la Plana, 2001. 350 pp. II RFE, 83 (2003), 198-202 (Bizarri).

53-337. Mogorrón Huerta, Pedro "Los diccionarios electrónicos fraseológicos, perspectivas para la lengua y la traducción". - Estudios de lingüistica: el verbo, coords. J. I. Cifuentes Honrubia y C. Marimón Llorca (Alicante, 2004), pp. 381-400. 53-338. Paredes, J. y E. Mutoz Ray (eds.) - Traducir la Edad Media. La traducrión de la literatura medieval románica (N. 51-523). II Incipit, 20/21 (2000-01), 169-176 (Amor). - V. núm. 52-1881.

53-339. Pasclat Febies, Isabei. et al. - Teoría, didáctica y práctica de la traducción. Netbiblo, La Coruña, 2003. 153 pp. II EHF, 26 (2004), 381-383 (Gómez). 53-340. Pfilicer y Saforcada, J J Ax AitoNo - Ensayo de una biblioteca de traductores españoles. Pres. Ginés M. 
Salido Ruiz; est. prelim. de Miguel Ángel Lama. - Universidad de Extremadura, Cáceres, 2003. II RLit, 65 (2003), 642 (Álvarez Barrientos).

53-341. Zamora, Fraicisco J. - "Planificación lingüística y traducción en español. José Robles Pasos y Max Dickmann". - RF, 115 (2003), 468483.

V. también núm. 325.

\section{HISTORIA DE LA LINGÜÍSTICA}

533-342. Abad, Francisco - "Ramón Menéndez Pidal (1869-1968)". - FGL, 2003, núms. 33/34, 287-289.

53-343. Alonso Ovaile, Lets Fernando "Aspectos gnoseológicos de la lingüística de Cuervo". - BICC, 53 (1998), 453-471.

53-344. ÁvTla, RAĹ - "De Lope Blanch a Juan: lengua hablada, lengua escrita, convergencias, divergencias, confesiones”. - Disquisiciones sobre filología hispánica. In memoriam Juan $M$. Lope Blanch (México, 2004), pp. 39-45.

53-345. Báez Pinal, Gloria Estela "Juan M. Lope Blanch y el Centro de Lingüística Hispánica". - Disquisiciones sobre filología hispánica. In memoriam Juan $M$. Lope Blanch (México, 2004), pp. 47-53.

53-346. Fifrtes Gltyérrez, Mar — "E1 papel de los misioneros en la descripción de las lenguas asiáticas por Lorenzo Hervás y Panduro (1735-1809)". — Missionary linguisticsLingüistica misionera. Selected papers from the First International Conference on Missionary Linguistics, Oslo, 13-16 March 2003, eds. O. Zwartjes \& E. Hovdhaugen (Amsterdam-Philadelphia, 2004), pp. 233-252.

53-347. Garza Clarón, Bettriz - "Francisco Pimentel, pionero de la lingüística (y de la etnología)". - Studies in honor of Denah Lida, eds. M. G. Berg \& Lanin A. Gyurko (Potomac, Maryland, 2005), pp. 290-296.

53-348. Korrver, E. F. K. - "Notes on missionary linguistics in North America". - Missionary linguistirs/Lingüistica misionera. Selected papers from the
First International Conference on Missionary Linguistics, Oslo, 13-16 March 2003, eds. O. Zwartjes \& E. Hovdhaugen (Amsterdam-Philadelphia, 2004), pp. 47-80.

53-349. LAPESA, RAFAEL - "Joan Corominas. Un catalán en mi recuerdo". FGL, 2003, núms. 33/34, 317-318. 53-350. López Morales, Humberto "Las academias de la lengua española y el hispanismo". - FGL, 2003, núms. 33/34, 51-56.

53-351. Molina, FRAy A. DE - Aqui comienca un vocabulario en la lengua castellana y mexicana, ed. M. Galeote (N. 501736). II $Z R P h, 119$ (2003), 782-783 (Lebsanft). - V. núm. 52-1886.

53-352. Montes Giraldo, José JoAQLín "El Diccionario de construcción y régimen Cuervo. Boceto histórico". - BICC, 53 (1998), 314-324.

53-353. Niederehe, HaNs-J. — "Los misioneros españoles y el estudio de las lenguas mayas". - Missionary linguistics/Lingüistica misionera. Selected papers from the First International Conference on Missionary Linguistics, Oslo, 13-16 March 2003, eds. O. Zwartjes \& E. Hordhaugen (Amsterdam-Philadelphia, 2004), pp.81-91.

53-354. OstLer, Nicholas - "The social roots of missionary linguistics". Missionary linguistics/Lingüistica misionera. Selected papers from the First International Conference on Missionary Linguistics, Oslo, 13-16 March 2003, eds. O. Zwartjes \& E. Hovdhaugen (Amsterdam-Philadelphia, 2004), pp. 33-46.

53-355. Penas Ibánez, M. Azlocena "Actualidad de la teoría lingüística sanctiana". - ALHis, 17/18 (200102), 25-49.

53-356. Polo, José - "Una obra clásica de Emilio Lorenzo. Marco historiográfico, contenidos, metodología (10)". - AFF, 26 (2003), 319-324.

53-357. Romero Ravili, Latre - "Bibliografía de Juan M. Lope Blanch". - Disquisiciones sobre filología hispánica. In memoriam Juan M. Lope Blanch (.México, 2004), pp. 185-214.

53-358. Salazar Gateia, Vextlra - "E1 tratamiento de la cópula verbal en la 
historia del pensamiento* lingüístico". - Estudios de lingüistica: el verbo, coords. J. L. Cifuentes Honrubia y C. Marimón Llorca (Alicante, 2004), pp. 529-557.

53-359. Santano Moreno, Juliáx - "Menéndez Pidal y la filología del 98. Estado latente e intrahistoria". Criticón, 2003, núms. 87/88/89, 787798.

53-360. Schmitt, Christlax - "La importancia de las gramáticas latinas para la historia del léxico español: la Ars Grammatica de Andreas Guterrius Cesarianus (1485)". - Historia del léxico español. Enfoques y aplicaciones. Homenaje a Bodo Müller, eds. J. Lüdtke y C. Schmitt (Frankfurt/M.-Madrid, 2004), pp. 137-150.

53-361. SCHËtz, GẼNher - "Cuervo y Dozy". - BICC, 53 (1998), 489-526.

53-362. SCHC̈tz, Gìther - "Cuervo y los cuervos". - BICC, 53 (1998), 340345.

53-363. SchL̈t $\angle$, Gìrher - "J. A. Rodríguez García y R. J. Cuervo frente al laísmo". — BICC, 53 (1998), 97-103.

53-364. Sch"̈tz, GïNTHer - "Rufino J. Cuervo y Francisco A. Gamboa". BICC, 53 (1998), 345-355.

53-365. Silvestri, Paolo - Le grammatiche italiane per ispanofoni (secoli XVI-XIX). - Edizioni dell'Orso, Torino, 2001. 201 pp. If HistL, 31 (2004), 170-175 (Lépinette).

53-366. Vaile, J. del y L. G. Stheemix (eds.) - The battle over Spanish between 1800 and 2000. Language ideologies and Hispanic intellectuals (N. 521833). II RFE, 83 (2003), 319-324 (López García).

53-367. Zamorayo Ageilar, Alfoxso "El verbo en las gramáticas del espanol (de Andrés Bello a Samuel Gili Gaya). Definición y clasificaciones tipológicas". - ALM, 40 (2002), 205240.

53-368. Zimmerman, Ki als - "La construcción del objeto de la historiografia de la lingüística misionera". Missionary linguistics/Lingüistica misionera. Selected papers from the First International Conference on Missionary Linguistics, Oslo, 13-16 March 2003, eds. O. Zwartjes \& E. Hovdhaugen (Amsterdam-Philadelphia, 2004), pp. 7-32.

V. también núm. 39, 43.

\section{LITERATURA HISPÁNICA}

\section{OBRAS GENERALES}

53-369. Alberte González, Antonio Retórica medieval. Historia de las artes predicatorias. - Centro de Lingüística Aplicada Atenea, Madrid, 2004. 331 pp. II RFLL, 22 (2004), 349-350 (Rojas Rodríguez).

53-370. Aivar, Garlos y José Manle Lucía Mecías (coords.) - Diccionario filológico de literatura medieval española. Textos y transmisión. - Castalia, Madrid, 2002. xxx +1178 pp. (Nueva Biblioteca de Erudición y Crítica, 21). II NRFH, 52 (2004), 182-187 (Higashi).

53-371. Álvarfz Barrientos, Joaquix "Cultura y política entre siglos". - Se hicieron literatos para ser políticos. Cultura y política en la España de Carlos $I V y$ Fermando VII, ed. J. Álvarez Barrientos (Madrid-Cádiz, 2004), pp. 11-24. 53-372. Álvarez Barrientos, Joaqlíx (ed.) - Espacios de la comunicación literaria. - CSIC, Madrid, 2002. 228 pp. $\|$ RLit, 65 (2003), 587-589 (Cornago Bernal).

53-373. Átvarez Ccartero, Izaskex "Un repaso bibliográfico del americanismo español a comienzos del siglo xxI". - Ibero, 2003, núm. 12, 201-221.

53-374. Álvarez de Miraxdi, Pedro "Rafael Lapesa (1908-2001): fidelidad y iustitia". - FGL, 2003, núms. 33/34, 321-323.

53-375. AMAT, JORDI - "Hilos de aproximación. El catalanismo dialogante y los congresos de poesía". - Ins, 2003, núm. 684, 3-7.

53-376. Andermaix, J. - Mapas de poder. Una arqueología literaria del espacio argentino (N. $50-1749$ ). II $R F, 115$ (2003), 523-524 (García Simón). V. núm. 52-1896.

53-377. Arambel-Guñazé, M. C. y C. E. MARTIN - Las mujeres toman la palabra. Escritura femenina del siglo XIX en 
Hispanoamérica. T. 1: Estudio. T. 2: Antología (N. 52-1900). II RFilR, 20 (2003), 310-314 (Hernández Quintana); Ibero, 2003, núm. 11, 267-268 (Paatz).

53-378. Arellano, Ignacio y José Antonio Mazzotтi (eds.) - Edición e interpretación de textos andinos. - Vervuert-Iberoamericana, Frankfurt/M.-Madrid, 2000. 282 pp. II Incipit, 22 (2002), 207-213 (Saracino).

53-379. Arenas monreal, Rogelio y $\mathrm{G}_{\mathrm{A}^{-}}$ Briela Ol.Ivares TORres - La voz a $t i$ debida. - UABC-Plaza y Valdés, México, 2001. II LMM, 14 (2003), 313-317 (Parra). [Entrevistas].

53-380. Balaguer, Vicente - La interpretación de la narración. La teoría de Paul Ricoeur. - EUNSA, Pamplona, 2002. 204 pp. (Anejos de "Rilce", 40). II RLit, 64 (2002), 601-603 (Pego Puigbó).

53-381. BaLdot, Georges — "Felipe II frente a las culturas y a los discursos prehispánicos de América. De la transculturación a la erradicación". - Carav, 2002, núm. 78, 37-56.

53-382. Bernecker, Walther L. - "México en el siglo xix: ¿años olvidados y perdidos?". - Ibero, 2003, núm. 9, 209-220.

53-383. Bi ecta, Alberto - "Hispanismo". - FGL, 2003, núms. 33/34, 73-78.

53-384. Blecua, Ai.berto - "Sobre la dignidad del hombre y las "Polyantheae»". - Ins, 2003, núm. 674, 37-40.

53-385. Botrel, JEAY-FrANCOIS - "Las asociaciones de hispanistas en Europa". - FGL, 2003, núms. 33/34, 79-91.

53-386. BOTTÈro, JEAN et al. - Cultura, pensamiento y escritura. - Gedisa, Barcelona, 1995. 188 pp. II BICC, 53 (1998), 152-159 (Cisneros Estupiñán).

53-387. Bolza Álvarez, Fernando "«No puedo leer nada». El corrector general Juan Vázquez del Mármol y la cultura escrita del Siglo de Oro". - Syntagma, 2002, núm. 0, 19-45.

53-388. Briesemeister, Dietrich - "Siegfried Leo Spitzer (1887-1960)". FGL, 2003, núms. 33/34, 295-297.

53-389. Bubnova, Tatuana (ed.) - En torno a la cultura popular de la risa. Nuevos fragmentos de M. M. Bajtín. - AnthroposFundación Cultural Eduardo Cohen,
Barcelona, 2000. 221 pp. II RLitPop, 2003, núm. 2, 157-162 (Domenella). 53-390. Caisso, Claldia - De vértigo, asombro y ensueño. Ensayos sobre literatura latinoamericana. - Vites, Rosario, 2001. 436 pp. II Ibero, 2003, núm. 9, 253-254 (Pérez Amador-Adam).

53-391. Camayd-Freixas, Erik \& José Eduardo González (eds.) - Primitivism and identity in Latin America. Essuys on art, literature, and culture. The University of Arizona Press, Tucson, 2000. xix + 285 pp. II Ibero, 2003 , núm. 9, 251-253 (Rings).

53-392. Cappeliı, Guido María - "La vida feliz. Sobre la literatura de estados castellana bajomedieval". - Ins, 2003, núm. 674, 14-15.

53-393. Caramuel, JuAx - Syntagma de arte typographica. Ed., trad. y glosa de Pablo Andrés Escapa. - Instituto de Historia del Libro y de la LecturaFundación Germán Sánchez Ruipérez-Fundación Duques de Soria, Soria, 2004. 240 pp. (Serie Minor, 3). 53-394. Carbajosa, Mónica y Pablo CarBajosa - La corte literaria de José Antonio. La primera generación cultural de La Falange. Pról. de José-Carlos Mainer. - Crítica, Barcelona, 2003. 368 pp. II RLit, 65 (2003), 661-664 (Pego Puigbó).

53-395. CASAs, A. - Bibliografía sistemática de teona literaria (N. 51-433). II RLit, 65 (2003), 260-262 (Pérez-Bowie). 53-396. Castro, Sixto J. - "La trama temporal del arte". - Diánoia, 52 (2004), 75-98.

53-397. Castro López, Octano - "México o Roma". - LMM, 14 (2003), 211-221. 53-398. Cátedra, Pedro M. y Anastasio Rojo - Bibliotecas y lecturas de mujeres. Siglo XI\% - Instituto de Historia del Libro y la Lectura-Fundación Duques de Soria-Fundación Germán Sánchez Ruipérez, Soria, 2004. 461 pp. (Serie Maior, 2).

53-399. Chevalier, Maxime - "Marcel Bataillon (1895-1977)". - FGL, 2003, núms. 33/34, 299-300.

53-400. Chicote, Gloria B. - "Saberes y conflictos en el hispanismo argentino". - FGL, 2003, núms. 33/34, 133-139. 
53-401. Chocano Mena, M. - La fortaleza docta. Elite letrada y dominación social en Méjico colonial (siglos Xi7-XVI) (N. 521921). II Carav, 2002, núm. 79, 281283 (Lavallé).

53-402. CHLL, PARK - "El hispanismo en Corea”. - FGL, 2003, núms. 33/34, 187-194.

53-403. Cobo Borda, Juan Gustavo "Aportaciones colombianas y españolas a la cultura universal". - BICC, 53 (1998), 334-340.

53-404. Codoñer, Carmex - "La recepción de los clásicos en la Edad Media". - Ins, 2003, núm. 675, 7-9.

53-405. COHEN, Esther - Con el diablo en el cuerpo. Filósofos y brujas en el Renacimiento. - Taurus, México, 2003. II SLL, 5 (2003), núm. 1, 253-259 (Lorenzano).

53-406. Cordốn, José Avtonio - "La edición en España”. - Syntagma, 2002, núm. 0, 113-136.

53-407. Correa Ramón, Amelina - Plumas femeninas en la literatura de Granada (siglos XIII-XX). Diccionario-Antología.

- Universidad, Granada, 2002. 460 pp. II RLit, 65 (2003), 606-608 (Castillejo Larrubia).

53-408. Cortijo Ocaña, A. - La Fernán Núñez Collection de la Bancroft Library, Berkeley: estudio y catálogo de los fondos castellanos (parte histórica) (N. 50-331). II Incipit, 22 (2002), 214-215 (Tenenbaum). - V. núm. 52-1925.

53-409. Costa Vieira, María Augusta "El hispanismo en Brasil". - FGL, 2003, núms. 33/34, 157-160.

53-410. Covo-Maurice, JacQleline "Un grand journaliste français au Mexique au xixe siècle: René Masson et Le Trait d'Union". - Carav, 2002, núm. 78, 105-125.

53-411. Cremades, Raíl y Ávgel EstebayCuando llegan las musas. Cómo trabajaban los grandes maestros de la literatura. Pról. de Pilar del Castillo. - Espasa-Calpe, Madrid, 2002. 412 pp. II Ibero, 2003, núm. 9, 247-248 (López de Abiada).

53-412. Crosas, F. (ed.) - La fermosa cobertura. Lecciones de literatura medieval. Navarra (N. 50-333). II Incipit, 22 (2002), 223-228 (Zubillaga). - V . núm. ว̌2-364.
53-413. D'Allemand, P. - Latin American cultural criticism. Re-interpreting a continent (N. 52-367). II Ibero, 2003, núm. 9, 249-251 (Schmidt-Welle). - V. núm. 52-1928.

53-414. Dexeus, Mercedes - "Los nuevos retos del archivo y la biblioteca al servicio del hispanismo". - FGL, 2003, núms. 33/34, 237-246.

53-415. Diaz de Castro, Francisco (ed.)

- Los Cuatro Vientos [Madrid, 1933].

- Renacimiento, Sevilla, 2000. 290 pp. II EHF, 26 (2004), 386-389 (Díez de Revenga).

53-416. Díaz-Plaja, ANa - "Guillermo Díaz-Plaja: teoría y práctica del diálogo". - Ins, 2003, núm. 684, 21-23.

53-417. Diego, José Luis De - ¿Quién de nosotros escribirá el "Facundo"? Intelectuales y escritores en Argentina (19701986). - Ediciones al Margen, La Plata, 2001. 317 pp. II Ibero, 2003, núm. 12, 259-261 (Schnirmajer). 53-418. Dolfi, Ladra - "Oreste Macrí (1913-1998): critica y militancia". FGL, 2003, núms. 33/34, 329-332.

53-419. Domíngeez Caparrós, José Análisis métrico y comentario estilístico de textos literarios. - UNED, Madrid, 2001. 185 pp. II RLit, 64 (2002), 605608 (Luján).

53-420. Dominglez Caparrós, José - Teoria de la literatura. - Editorial Centro de Estudios Ramón Areces, Madrid, 2002. 445 pp. II RLit, 65 (2003), 262264 (Garrido Gallardo).

53-421. Doremus, Anne T. - Culture, politics, and national identity in Mexican literature and film, 1929-1952. - P. Lang, New York, 2001. 206 pp. II Ibero, 2003, núm. 11, 269-270 (Sandner). 53-422. Egido, Acrora - "Mapa del hispanismo". - FGL, 2003, núms. 33/ 34, 15-37.

53-423. Estebax, Ávger y Áxgel Cadelo "Joaquín Antonio Peñaloza: conciencia y dignidad del hombre contemporáneo". - $T C, 2002$, núm. 11, 25-41.

53-424. F. Garvalho, José Adriano de "Lecturas de príncipes y aristócratas". -İns, 2003, núm. 675, 2-7.

53-425. FALlows, NOEL - "Aproximaciones a la medicina militar en la Edad 
Media". - Literatura y conocimiento medieval. Actas de las VIII Jornadas Me dievales, eds. L. von der Walde, C. Company y A. González (México, 2003), pp. 475-493.

53-426. Féliz Bolaños, Álvaro y Glstayo Verdesro (eds.) - Colonialism past and present: Reading and writing about colonial Latin America today. - SUNY Press, Albany, 2002. 300 pp. II RCEH, 27 (2003), 571-573 (Hill).

53-427. FernáNdez, Ricardo - "Otis Howard Green (1898-1978)". FGL, 2003, núms. 33/34, 305-307.

53-428. Fervádez Cifuextes, Luis - "Ia literatura española en los Estados Lnidos: historia de sus historias". Historia literaria/Historia de la literatu$r a$, ed. L. Romero Tobar (Zaragoza, 2004), pp. 253-272.

53-429. Ferviduez Urtasún, Rosa - Poéticas del modernismo español. - EUNSA, Pamplona, 2002. 167 pp. II RLit, 65 (2003), 316-319 (Díez de Revenga).

53-430. FINE, RLTH - "El hispanismo en Israel". - FGL, 2003, núms. 33/34, 107-115.

53-431. Fiantá de Fervíndez, Nudda M. Itinerarios literarios. Construcciones y reconstrucciones identitarias. - Vervuert-Iberoamericana, Frankfurt/M.Madrid, 2001. 138 pp. II Ibero, 2003, núm. 12, 257-258 (Carrillo Zeiter).

53-432. Flórez Miglelel, Cirilo - "El libro científico y sus lectores en la Edad Media". - Íns, 2003, núm. 675, 14-18.

53-433. Forster, Merlin H. (ed.) - Las vanguardias literarias en México y la América Central. Bibliografía y antologia crítica. - Vervuert-Iberoamericana, Frankfurt/M.-Madrid, 2001. 355 pp. II Ibero, 2003, núm. 10, 219-222 (Gewecke).

53-434. Frago Gracia, Juax ANtono "Hispanismo, hispanista". - FGI, 2003, núms. 33/34, 41-49.

53-435. G. P., E. C. y F. I. - "El hispanismo y el mundo editorial". - $F G L$, 2003, núms. 33/34, 275-280.

53-436. García Cancind, Néstor - Lati noamericanos buscando lugar en este siglo. - Paidós, Buenos Aires, 2002. II
EUSB, 2003-04, núms. 22/23, 389-406 (Laera).

53-437. Garcia Montero, Llis - "Poética, política, ideología”. - Íns, 2002, núms. $671 / 672,19-20$.

53-438. Garcia Saxto-Tomás, Exrigle "Las revistas internacionales en la difusión del hispanismo". - FGL, 2003, núms. 33/34, 209-214.

53-439. Garcia y García, ANtonio - "La enseñanza reglada del derecho durante la baja Edad Media". - Ins, 2003, núm. 675, 12-14.

53-440. Gaspar, Catalina - "Los umbrales de la travesía textual en la «metaficción productiva»". - BICC, 53 (1998), 271-293.

53-441. Gilman Shermax, ANita - "John Donne and Spain". - Studies in honor of Denah Lida, eds. M. G. Berg \& Lanin A. Gyurko (Potomac, Maryland, 2005), pp. 71-83.

53-442. Godinas, Latrette - "Los Proverbios de Séneca en la discusión en torno al humanismo castellano del siglo $\mathrm{XV}$ ". - Literatura y conocimiento medieval. Actas de las VIII Jomadas Medievales, eds. L. von der Walde, C. Company y A. González (México, 2003), pp. 296.

53-443. Gómez Redondo, FerNando - $A r$ tes poéticas medievales. - Eds. Laberinto, Madrid, 2000. II Incipit, 20/21 (2000-01), 177-184 (Gómez).

53-444. Gómez Redondo, Fernando - "El lenguaje de la ficción en el siglo xv: tratadistas y creadores". - Edad de Oro, 23 (2004), 9-32.

53-445. González, Aurei io - "El hispanismo en México". - FGL, 2003, núms. 33/34, 125-131.

53-446. Gonzallez Rodríglez, Jaime "Los franciscanos y la cultura en México (y III). Los franciscanos y los grandes temas del debate público". - AIA, 64 (2004), 197-420.

53-447. Gonzailez. Troyano, Aiberto "La singularidad gaditana entre uno y otro siglo". - Se hicieron literatos para ser políticos. Cultura y politica en la España de Carlos N y Fermando VII, ed. J. Álvarez Barrientos (Madrid-Cádiz, 2004), pp. 131-165. 
53-448. Grandis, Rita de \& Zilì Bernd (eds.) - Unforseeable Americas: Questioning cultural hybridity in the Americas. - Rodopi, Amsterdam, 2000. xxix + 310 pp. II RCEH, 27 (2003), 399-401 (Lindstrom).

53-449. Gyssels, Kathleen, Isabel Hoving \& MagGie Avi Bowers (eds.) - Covergences and interferences. Newness in intercultural practices. - Rodopi, Amsterdam-Philadelphia, 2001. 293 pp. II Ibero, 2003, núm. 12, 246-248 (Phaf-Reichenberger).

53-450. HaNsen, JoÃo AdOlfo - "Notas sobre el Barroco". - RFLL, 22 (2004), 111-131.

53-451. Hernández, Francisco J. - "Materiales para una guía del hispanismo universitario en Canadá". - FGL, 2003, núms. 33/34, 141-148.

53-452. Hernández Esteban, María - El texto en el texto. Lectura de géneros literarios. - Universidad, Málaga, 2001. 498 pp. If $R F E, 83$ (2003), 189-194 (Díaz-Corralejo); RLit, 64 (2002), 589-593 (López Suárez).

53-453. HernáNdez Glerrero, José ANtoNo - "Defensa de la retórica barroca". - Edad de Oro, 23 (2004), 41-51.

53-454. HiLl, R. - Sceptres and sciences in the Spains. Four humanists and the New Philosophy (ca. 1680-1740) (N. 501802). II RCEH, 27 (2003), 586-588 (Pérez Magallón).

53-455. Hö̀z, K. - Das Fremde, das Eigene, das Andere. Die Inszenierung kultureller und geschlechtlicher Identität in Lateinamerika (N. 49-400). II LMM, 14 (2003), 306-312 (Pappe). - V. núm. $52-1954$.

53-456. Heterta González, Ángeles - La Europa periférica: Rusia y España ante el fenómeno de la modernidad. - Universidade, Santiago de Compostela, 2004. 334 pp. (Monografias da Universidade de Santiago de Compostela, 213).

53-457. Illades, C. y A. SaNdoval - Espacio social y representación literaria en el siglo xix (N. 52-1955). II L.MM, 14 (2003), 217-227 (Negrín).

53-458. Jacobs, Helmut C. - Belleza y buen gusto. Las teorías de las artes en la literatura española del siglo XVIII. — Vervuert-Iberoamericana, Frankfurt/M.-
Madrid, 2001. 378 pp. II RLit, 65 (2003), 637-641 (Angulo Egea); Ibero, 2003, núm. 10, 204-205 (Úbeda de los Cobos).

53-459. Jalralde, Pablo - "Don Eugenio Asensio (1902-1996)". - FGL, 2003, núms. 33/34, 313-316.

53-460. Juaristi, Jon - "El Instituto Cervantes y el hispanismo". - FGL, 2003, núms. 33/34, 259-263.

53-461. Kirkpatrick, Susan - Mujer, modernismo y vanguardia en España (1898-1931). Trad. de Jacqueline Cruz. - Cátedra, Madrid, 2003. 322 pp. II RLit, 65 (2003), 650-655 (Sánchez Llama).

53-462. KNALTH, K. AlFoNS - "Sol oriens in occiduo. Sinn und Bild Lateinamerikas". - I, 2003, núm. 57, 80-113.

53-463. LAHOZ, Lucí - "El libro sin palabras. La lectura iconográfica". Ins, 2003, núm. 675, 31-36.

53-464. LARA MARTíNez, RAfaEl - La tormenta entre las manos. Ensayos sobre literatura salvadoreña. - Dirección de Publicaciones e Impresos, San Salvador, 2000. 353 pp. II Carav, 2003, núm. 81, 348-352 (Bourdois).

53-465. Lechlga Solís, Graciela - "La crítica literaria de Jean-Pierre $\mathrm{Ri}$ chard y el método de archivo de Michel Foucault". - SLL, 5 (2003), núm. 1, 129-141.

53-466. LERNER, ISAÍAS - "María Rosa Lida de Malkiel". - FGL, 2003, núms. 33/34, 325-327.

53-467. LeVINSON, BRETT - The ends of liierature. The Latin American "boom" in the neoliberal marketplace. - Stanford University Press, Stanford, 2001. xii + 208 pp. II RCEH, 27 (2003), 590-592 (Chanady).

53-468. LidA, ClaRA E. - "Itinerarios culturales y memoria en el exilio espanol en México". - Studies in honor of Denah Lida, eds. M. G. Berg \& Lanin A. Gyurko (Potomac, Maryland, 2005), pp. 258-269.

53-469. LIDA, Maria Rosa - "Amado Alonso (1896-1952)". — FGL, 2003, núms. 33/34, 301-304.

53-470. Lida, Miranda y SOledad - "Un discurso de la hispanidad: retórica y política en el nacionalismo católico 
argentino en la década de 1930". Studies in honor of Denah Lida, eds. M. G. Berg \& Lanin A. Gyurko (Potomac, Maryland, 2005), pp. 306-312.

53-471. Lindstrom, NaOMi - The social conscience of Latin American writing. University of Texas Press, Austin, 1998. 187 pp. II RCEH, 26 (2002), 565-567 (de Grandis).

53-472. Llorexte, María EMma - "Erotismo y pornografia: revisión de enfoques y aproximaciones al concepto de erotismo y de literatura erótica". - ALM, 40 (2002), 359-375.

53-473. LópFz Al oNso, CovadONGa y ArletTE SÉkÉ (eds.) - Nuevos géneros discursivos: los textos electrónicos. - Biblioteca Nueva, Madrid, 2003. 219 pp. (Estudios Críticos de Literatura, 9). II RGG, 39 (2004), 111-113 (Niederehe).

53-474. Lópel de Abiada, José Manuel, Havs Jörg Nelschäfer y Augusta LóPEZ Berrasocchi (eds.) - Entre el ocio y el negocio: industria editorial y literatura en la España de los 90 . - Verbum, Madrid, 2001. 335 pp. II Ibero, 2003, núm. 9, 243-245 (García).

53-475. López. García, Dámaso - "Del espíritu de la época". - RFLL, 22 (2004), 133-144.

53-476. López LeNci, YAzMíN - El laboratorio de la vanguardia en el Peri. Trayectoria de una génesis a través de las revistas culturales de los años veinte. - Editorial Horizonte, Lima, 1999. II Carav, 2002, núm. 78, 274-276 (Pöppel).

53-477. López-Vidriero, María Luisa Speculom Principom. Nuevas lecturas curriculares, nuevos usos de la Librería del Príncipe en el Setecientos. - Biblioteca Nueva-Instituto de Historia del Libro y de la Lectura-Fundación Germán Sánchez Ruipérez-Fundación Duques de Soria, Madrid-Soria, 2002. 620 pp. (Serie Maior, 1).

53-478. Llcía Megías, José Manuel "Imprenta y lengua literaria en los Siglos de Oro: el caso de los libros de caballerías castellanos". - Edad de Oro, 23 (2004), 199-229.

53-479. Lucía Megías, J. M. - Imprenta y libros de caballerias (N. 52-2258). II Incipil, 20/21 (2000-01), 243-247 (Lastra Paz).
53-480. Madronta., AbrahaM - "El hispanismo en España”. - $F G L, 2003$, núms. 33/34, 161-176.

53-481. MAESENEer, R. DE (ed.) - Convergencias e interferencias. Escribir desde los borde(r)s (N. 49-2041). II Ibero, 2003, núm. 12, 246-248 (Phaf-Rheinberger). - V. núm. 51-2126.

53-482. Mangini, Shirley - Las modernas de Madrid. Las grandes intelectuales españolas de la vanguardia. - Ediciones Península, Barcelona, 2001. 266 pp. II Ibero, 2003, núm. 11, 251-252 (Truxa).

53-483. Manzoni, Cer.na - Un dilema cu bano. Nacionalismo y vanguardia. Casa de las Américas, La Habana, 2003. 345 pp. II Ibero, 2003, núm. 9, 256-257 (Phaf-Rheinberger).

53-484. Marañón Ripoll, Miglel - "El hispanismo en internet: agenda". FGL, 2003, núms. 33/34, 371-378.

53-485. Martín Abad, JLliÁx - Post-incunables ibéricos. - Ollero y Ramos, Madrid, 2001.572 pp. II RFE, 83 (2003), 202-207 (Jauralde Pou).

53-486. Martínez Fervávdez, José EnriQUE - La intertextualidad literaria. (Base teórica y práctica textual). - Cátedra, Madrid, 2001. 215 pp. II Ibero, 2003, núm. 9, 237-239 (Herrero).

53-487. Martínez LlNa, Esther - Estudio e indice onomástico del "Diario de México". Primera época (1805-1812). UNAM, México, 2001. 1xxiii + 332 pp. II LMM, 14 (2003), 291-293 (Quiñones Melgoza).

53-488. MASIELlo, FrancINe - The art of transition: Latin American culture and neoliberal crisis. - Duke University Press, Durham, 2001. 339 pp. II RCEH, 27 (2003), 592-594 (Holmes).

53-489. Mattalía, Sonit - Máscaras suele vestir. Pasión y reonuelta: escritura de mujeres en América Latina. - Vervuert, Madrid, 2003. 328 pp. II RLit, 65 (2003), 602-606 (Ferrús Antón).

53-490. Matzat, Wolfgagig \& Bervflard Telber (Hrsg.) - Welterfahrung-Selbsterfahrung. Konstitution und Verhandlung von Subjektivität in der spanischen Literatur der frühen Neuzeit. - Niemeyer, Tübingen, 2000. 377 pp. II Ibero, 2003, núm. 9, 221-223 (Graf). 
53-491. MENA, LCL - "Caos eń la ciudad: La Habana en los 1830". - EUSB, 2003-04, núms. 22/23, 303-327.

53-492. Méndez, M. A. - Secretos del Oficio. Avatares de la Inquisición novohispana (N. 52-1986). II Carav, 2002, núm. 78, 261-262 (Bénassy).

53-493. Meyer, Elgenta y Era Salgado Un refugio en la memoria. La experiencia de los exilios latinoamericanos en México. - UNAM-Océano, México, 2002. 361 pp. II AEla, 38 (2004), 245-250 (Ramírez Hernández).

53-494. Meyer-Minnfmany, Klads, Ana Luengo, Danifia Péréz y Efficger "La Ponencia colectiva (1937) de Arturo Serrano Plaja: una toma de posición literaria y política en la Guerra Civil". - RLit, 65 (2003), 447-470.

53-495. Mijares Ramíkez, Ivonne - Escribanos y escrituras públicas en el siglo XvI: el caso de la ciudad de México. UNAM, México, 1997. 306 pp. II Carav, 2002, núm. 78, 253-254 (Langue) .

53-496. Mísglez Arraiz, Norberto (dir.) - Literatura española y cine. Editorial Complutense, Madrid, 2002. 215 pp. II RLit, 65 (2003), 594599 (Bonilla Cerezo).

53-497. Molina Romero, M. Carmex "Madres malas y literatura del exilio". - RFLL, 22 (2004), 175-185.

53-498. Mor L, Jarme - "Un taller de imprenta en Sevilla a mediados del siglo хІт”. - Syntagma, 2002, núm. 0, 87-94.

53-499. Moreli. G. (ed.) - Iudus. Cine, arte y deporte en la literatura española de vanguardia (N. 52-530). II Ibero, 2003, núm. 9, 234-236 (Caparrós Esperante).

53-500. Morexo Hersíidez, C. - Literatura e hipertexto: de la cultura manuscrita a la cultura electrónica (N. s0-1818). II RLil, 64 (2002), 256-257 (Hernández Durán).

53-501. Moret, XIVIER - Tiempo de editores. - Destino, Barcelona, 2003. 400 pp. II Ibero, 2003, núm. 12, 233-235 (Pohl).

53-502. Mekarolsky, JAx-Signo, función y valor. Estética y semiótica del arle. Ed., introd. y trad. de Jarmila Jandová y
Emil Volek. - Plaza y Janés, Santa Fe de Bogotá, 2001. 503 pp. II RLit, 65 (2003), 259-260 (Garrido Gallardo).

53-503. Necshäfer, Hans-Jörg - "Hispanística: pasado y presente de una disciplina con futuro o contra las sempiternas lamentaciones". - Ibero, 2003, núm. 11, 181-188.

53-504. Nirenberg, David - "Alfonso VIII and the Jewess of Toledo: A political affair". - Studies in honor of Denah Lida, eds. M. G. Berg \& Lanin A. Gyurko (Potomac, Maryland, 2005), pp. 27-43.

53-505. Orihleia, Antonio - "Fragmentos de poética". - Ins, 2002, núms. 67.1/672, 41-42.

53-506. Ortegd, Julo - "El hispanismo entre dos orillas". - FGL, 2003, núms. 33/34, 117-124.

53-507. Ortegia, Julio - "Post-teoría y estudios transatlánticos". - Ibero, 2003, núm. 9, 109-117.

53-508. Oscxa, Raraer - Tiempo, materia y texto. Una reflexión sobre la revista literaria. - Reichenberger, Kassel, 1998: 108 pp. II Incipit, 20/21 (200001), 252-258 (Petruccelli).

53-509. Páiz. Hernánde7, María Isabel de (ed.) - La memoria de los libros. Estudios sobre la historia del libro y de la lectura en Europa y América Latina. Instituto de Historia del Libro y de la Lectura-Biblioteca Nueva, Soria-Madrid, 2004.2 ts.

53-510. Palacios Feriáxdez, E. - La mujer y las letras en la España del siglo XIIII (N. 52-2000) . II RLil, 65 (2003), 292294 (Angulo Egea).

53-511. Paraíso, IsAbei - Las voces de Psique: estudios de teoria y crítica literaria. - Universidad, Murcia, 2001. 336 pp. II RLit, 65 (2003), 584-587 (Llera).

53-512. Patxison, D. G. (ed.) - Textos épicos castellanos: problemas de edición y critica (N. 48-2278). II NRFH, 52 (2004), 187-190 (Higashi). - V. núm. 52-584.

53-513. Pedraza JiméNez, F. B. y M. RodríGLEZ. CACERES - Manual de literatura española. T. 13: Posguerra: narradores (N. 50-1825). II RLit, 64 (2002), 611613 (Torres-Pou). 
53-514. Pérez Magallón, J. - Construyendo la modernidad. La cultura española en el "tiempo de los novatores" (16751725) (N. 51-526). II RCEH, 27 (2003), 594-596 (Hafter). - V. núm. $52-2003$.

53-515. Pino, J. M. del y F. LaRcbia Prado (eds.) - El hispanismo en los Estados Unidos. Discursos críticos/prácticas textuales (N. 52-443). II RCEH, 26 (2002), 557-560 (Pérez-Magallón).

53-516. Polluav, Leo-La separación de los estilos. Para una historia de la conciencia literaria argentina. - Vervuert-Iberoamericana, Frankfurt/M.-Madrid, 1998. 152 pp. (Teoría y Crítica de la Cultura y la Literatura, 13).

53-517. Pozuelo Yvancos, José María "El hispanismo y el canon". - FGL, 2003, núms. 33/34, 215-222.

53-518. QLintero, Juan Carlos - Fulguración del espacio. Letras e imaginario institucional de la Revolución cubana (1960-1971). - Beatriz Viterbo, Rosario, 2002. 574 pp. II Ibero, 2003, núm. 12, 251-253 (Bernabé).

53-519. Regazzoni, Susara (ed.) - Cuba: una literatura sin fronteras. - Vervuert-Iberoamericana, Frankfurt/M.Madrid, 2001. 148 pp. II Ibero, 2003, núm. 12, p. 253 (Böhringer).

53-520. Reig Tapla, Alberto - Memoria de la Guerra Civil. Los mitos de la tribu. - Alianza, Madrid, 1999. 398 pp. II RCEH, 26 (2002), 573-575 (Bertrand de Muñoz).

53-521. Rodríglez-Adrados, Francisco - "Humanismo greco-latino en Hispanoamérica”. - FGL, 2003, núms. 33/34, 223-228.

53-522. Rodríguez Sánchez de León, M. José - "Prensa periódica y crítica literaria". - Se hicieron literatos para ser políticos. Cultura y política en la España de Carlos IV y Fermando VII, ed. J. Álvarez Barrientos (Madrid-Cádiz, 2004), pp. 25-62.

53-523. Romero Ferrer, Alberto y FerNANdo Durán López (coords.) - 25 escritores gaditanos raros y olvidados. Diputación, Cádiz, 2001. 285 pp. II RLit, 64 (2002), 613-614 (Muñoz Sempere).
53-524. Ruedas de la Serna, Jorge - "De la geisha a la mujer de hierro o la crítica en la edición de textos". LMM, 13 (2002), 117-127.

53-525. Ruedas de la Serna, Jorge - "El resplandor intelectual de las imágenes. A propósito de un libro de José Pascual Buxó”. - AEla, 38 (2004), 179-187.

53-526. Ruiz García, Elisa - Los libros de Isabel la Católica. Arqueología de un patrimonio escrito. - Instituto de Historia del Libro y de la Lectura-Fundación Duques de Soria-Fundación Germán Sánchez Ruipérez, Soria, 2004. 653 pp. (Serie Maior, 6).

53-527. Sáenz de Casas, María del Carmen — "George Ticknor (1791-1871)". FGL, 2003, núms. 33/34, 283-285. 53-528. Salas, J. de y D. Briesemeister (eds.) - Las influencias de las culturas académicas alemana y española desde 1898 hasta 1936 (N. 52-2015). II RLit, 65 (2003), 319-322 (Pardellas Velay). 53-529. Salvador, Nélida y Elisa Rey (eds.) - Los espacios de la literatura. Academia del Sur, Buenos Aires, 2001. 153 pp. II Ibero, 2003, núm. 11, 263-265 (Tomassini).

53-530. Sánchez Laílla, Luis - "Bibliografia ordenada sobre el hispanismo". - FGL, 2003, núms. 33/34, 379-395.

53-531. Sánchez Llama, I. - Galería de escritoras isabelinas. (La prensa periódica entre 1833-1895) (N. 51-2155). II RLit, 64 (2002), 292-296 (Ferrús Antón). 53-532. Santos, Lidia - Kitsch tropical. Los medios en la literatura y el arte del América Latina. - Vervuert-Iberoamericana, Frankfurt/M.-Madrid, 2001. 237 pp. II Ibero, 2003, núm. 11, 265-267 (de Maeseneer).

53-533. Sarto, ANA deL - "Reflexiones sobre el latinoamericanismo. Una crítica al pensamiento de Alberto Moreiras". - EUSB, 2003-04, núms. 22/23, 331-342.

53-534. SAwicki, PIOTR - Las plumas que valieron por pistolas. Las letras en pugna con la historia reciente de España. Wydawnictwo Uniwersytetu Wroćawskiego, Wroćaw, 2001. 224 pp. II 
RLit, 65 (2003), 322-325 '(Mansberger Amorós).

53-535. Schulman, Ivan A. - El proyecto inconcluso. La vigencia del modernismo. - Siglo XXI, México, 2002. 247 pp. II $L M M, 14$ (2003), 301-305 (Mandujano Jacobo).

53-536. SChwartz, Lí - "Los hispanismos emergentes". - FGL, 2003, núms. 33/34, 93-97.

53-537. Segura Graíño, CrustiNa (coord.) - Feminismo y misoginia en la literatura española. Fuentes literarias para la historia de las mujeres. - Narcea, Madrid, 2001. 245 pp. II RLit, 65 (2003), 599-602 (Gómez Sierra).

53-538. Sepúl veda Herrera, María Teresa - Procesos por idolatrías al cacique, gobernadores y sacerdotes de Yanhuitlán, 1544-1546. - INAH, México, 1999. 301 pp. II Carav, 2002, núm. 78, 255256 (Grunberg).

53-539. Serrano Asenjo, Enrique - "La invención del 27 desde dentro: el caso de Ángel del Río". - Historia literaria/Historia de la literatura, ed. L. Romero Tobar (Zaragoza, 2004), pp. 369-390.

53-540. Serrayo Martix, Eliseo - "Hispanismo e historia”. - FGL, 2003, núms. 33/34, 229-235.

53-541. Severin, Dorothy S. - "Del manuscrito a la imprenta en la época de los Reyes Católicos". - Literatura y conocimiento medieval. Actas de las VIII Jornadas Medievales, eds. L. von der Walde, C. Company y A. González (México, 2003), pp. 33-48.

53-542. Shimizc, Norio - "El hispanismo en Japón". - FGL, 2003, núms. 33/34, 177-185.

53-543. Sierra Macarrón, LeONor "Oralidad y cultura escrita en Castilla y León (siglos XI-XIII)". - Literatura y conocimiento medieval. Actas de las VIII Jornadas Medievales, eds. L. von der Walde, C. Company y A. González (México, 2003), pp. 457-472.

53-544. SORIA OLMEdO, ANdrês - "Dámaso Alonso (1898-1990)". — $F G L$, 2003, núms. 33/34, 309-311.

53-545. Tenenbalm, Felipe - "El sistema de transcripción del Hispanic Seminar of Medieval Studies (Madison,
Wisconsin)". - Incipit, 20/21 (200001 ), 153-157.

53-546. Terry, Arthur - "Edward M. Wilson (1906-1977)". - FGL, 2003, núms. 33/34, 319-320.

53-547. Torrecilla, Jesús - España exótica. La formación de la imagen española moderna. - Society of Spanish and Spanish-American Studies, Boulder, CO, 2004. $205 \mathrm{pp}$.

53-548. Tortosa, Virgilio - Conflictos y tensiones. Individualismo y literatura en el fin de siglo. - Universidad de Alicante, Murcia, 2002. 452 pp. II RLit, 65 (2003), 340-342 (Bartolomé Porcar).

53-549. Trancón Laglnas, M. - La literatura fantástica en la prensa del Romanticismo (N. 51-835). II RLit, 64 (2002), 287-289 (Bartolomé Porcar).

53-550. Trigo, BeNigno - Subjects of crisis. Race and gender as disease in Latin America. - University Press of New England, Hanover, 2000. 157 pp. II RCEH, 27 (2003), 397-399 (Rowinsky).

53-551. URIBE, AvTonio - "El surgimiento de una literatura hispanoafricana: Guinea Ecuatorial". BHH, 2004, núm. 4, 93-103.

53-552. VALIS, NOËL - The culture of "cursileria". Bad taste, kitsch, and class in modern Spain. - Duke University Press, Durham-London, 2002. 406 pp. II RLit, 65 (2003), 274-279 (Sánchez Llama).

53-553. VARgas Liosa, Mario - "El hispanista". - FGL, 2003, núms. 33/34, $357-361$.

53-554. Vázqlez, María Cecilia y Sergio Pastormerlo (eds.) - Literatura ar gentina. Perspectivas de fin de siglo. EUDEBA, Buenos Aires, 2001. 602 pp. II Ibero, 2003, núm. 11, 280-282 (Mallol).

53-5̌55. VEGA, JESLSA - "Imágenes para un cambio de siglo". - Se hicieron literatos para ser políticos. Cultura y política en la España de Carlos IV y Fernando VII, ed. J. Álvarez Barrientos (MadridCádiz, 2004), pp. 83-129.

53-556. Venier, Martha Eiena - "Teoría de los animales en Brunetto Latini". - Literatura y conocimiento medieoal. 
Actas de las VIII Jornadas Medievales, eds. L. von der Walde, C. Company y A. González (México, 2003), pp. 495-502.

53-557. Vervliert, Klaus D. - "El papel de las editoriales y las librerías en el hispanismo". - FGL, 2003, núms. 33/34, 269-273.

53-558. Vidal Olineras, Jalme - "Rafael Santos Torroella y la editorial Cobalto. Promoción cultural en la posguerra (I)". - Ins, 2003, núm. 684, 11-15.

53-559. Villariño, Teresa - La idea de la literatura. Fenomenología y estilística literaria en el ámbito hispánico. - Anexos de Tropelias, Zaragoza, 2001. II RLit, 65 (2003), 577-580 (Romo Feito).

53-560. Víñez Sánchez, ANTonia - El trovador Gonçal'Eanes Dovinhal. Estudio histórico y edición. - Universidade, Santiago de Compostela, 2004. 334 pp. (Verba. Anuario Galego de Filoloxía, Anexo 55).

53-561. WARD, ThOMAs - La teoría literaria. Romanticismo, krausismo y modernismo ante la "globalización" industrial. The University of Mississippi, Mississippi, 2004. $178 \mathrm{pp}$.

53-562. WEIS, JASON - The lights of home: A century of Latin American writers in Paris. - Routledge, New York, 2003. 278 pp. II Brújula, 3 (2004), núm. 1, 169-171 (Pérez).

53-563. WextzlafF-Eggebert, H. (ed.) Naciendo el hombre nuevo... Fundir literatura, artes y vida como práctica de las vanguardias en el mundo ibérico (N. 49464). II $R F, 115$ (2003), 146-148 (Albert). - V. núm. 52-2038.

53-564. WHITE, HADDEN - El texto histórico como artefacto literario. Trad. de Verónica Tozzi. - Paidós, Barcelona, 2003. 252 pp. II RLit, 65 (2003), 589594 (Escrig Aparicio).

53-565. YÚdice, GeORGE - El recurso de la cultura. Uso de la cultura en la era global. - Gedisa, Barcelona, 2002. II EUSB, 2003-04, núms. 22/23, 389-406 (Laera).

53-566. Zamora Calvo, María Jesús "Madrid: cuna de embrujos, hechizos y represiones en el Siglo de Oro". Alpha, 2004, núm. 20, 279-292.
53-567. Zevallos Agullar, Juan - "Vanguardismo literario andino y modernidades alternativas en el sur peruano (1900-1930)". - $B H H$, 2004, núm. 4, 79-91.

\section{HOMENAJES Y ACTAS DE CONGRESOS}

53-568. Álvarez Barrientos, JoaQuíN (ed.) - Se hicieron literatos para ser políticos. Cultura y política en la España de Carlos IV y Fernando VII. - Biblioteca Nueva-Universidad de Cádiz, Madrid-Cádiz, 2004. 382 pp.

53-569. Berg, Mary G. \& Lanin A. Gyurko (eds.) - Studies in honor of Denah Lida. - Scripta Humanistica, Potomac, Maryland, 2005. 413 pp.

53-570. Hassán, IACOB M. y Ricardo IzQUIERDO BENITO (coords.) - Judios en la literatura española. IX Curso Cultural Hispanojudio y Sefardi de la Universidad de Castilla-La Mancha. - Universidad de Castilla-La Mancha, Cuenca, 2001. 510 pp. II $A L M, 40$ (2002), 427432 (Ontañón de Lope).

53-571. JIMÉNEZ DE BÁEz, Y. (ed.) - Varia linguiistica y literaria. T. 3: Literatura: siglos $X I X$ y $X X$ (N. 46-435). II BICC, 53 (1998), 404-426 (Cisneros Estupiñán). - V. núm. 49-492.

53-572. MAsera, M. (coord.) - La otra Nueva España. La palabra marginada en la Colonia (N. 52-487). II RLitPop, 2003, núm. 1, 197-206 (Frenk); NRFH, 52 (2004), 190-196 (Pérez Daniel).

53-573. Olea Franco, R. (ed.) - Literatura mexicana del otro fin de siglo (N. 51584). II Ibero, 2003, núm. 12, 248-250 (Bellini). - V. núm. 51-2186.

53-574. Oviedo, Rocío (ed.) - México en la encrucijada. Octavio Paz y la cultura hispánica en el fin de siglo. (Homenaje a Giuseppe Bellini y Luis Sáinz de Medrano). - Ediciones Gondo, Madrid, 2000. 382 pp. I| Carav, 2002, núm. 79, p. 314 (Pailler).

53-575. Romero, EleNa (ed.) - Judaísmo hispano. Estudios en memoria de José Luis Lacave Riaño. - CSIC, Madrid, 2002. 2 ts.: 874 pp. II RFE, 83 (2003), 324327 (García Mouton). 
53-576. SChMidT-Welle, FriedHÉlm (ed.) Antonio Cornejo Polary los estudios latinoamericanos. - Instituto Internacional de Literatura Iberoamericana, PittsburghBerlin, 2002. 328 pp. II Ibero, 2003, núm. 12, 241-243 (Zevallos Aguilar).

53-577. Simson, I. - Das Siglo de Oro. Spanische Literatur, Gesellschaft und Kultur des 16. und 17. Jarhunderts (N. 522024). II $R F, 115$ (2003), 547-549 (Ehrlicher); Ibero, 2003, núm. 10, 195-197 (Escribano).

53-578. Spang, Kurt (ed.) - Actas del Coloquio Internacional "Los géneros en las artes". - Universidad de Navarra, Pamplona, 2001. 200 pp. II RLit, 64 (2002), 594-596 (Galván).

53-579. Spang, Kurt (ed.) - Las artes y sus modos. Actas del Coloquio Internacional "Las artes y sus modos". - EUNSA, Pamplona, 2003. II RLit, 65 (2003), 580-584 (García Barrientos).

53-580. Toro Ceballos, Francisco y Bienvenido Morros (eds.) - Juan Ruiz, Arcipreste de Hita, y el "Libro de buen amor". Congreso Internacional del Centro para la Edición de los Clásicos Españoles, patrocinado por el área de cultura del Ayuntamiento de Alcalá la Real, con la colaboración del Instituto de Estudios Giennenses de la Diputación Provincial de Jaén. Se celebró en Alcalá la Real del 9 al 11 de mayo del año MMII. - Ayuntamiento de Alcalá la Real-Centro para la Edición de los Clásicos Españoles, Alcalá la Real, 2004. 462 pp.

53-581. "Venida es venida": postillae in "Corpus", Margit Frenk. Homenaje del SEMyR - Seminario de Estudios Medievales y Renacentistas, Salamanca, 2001. II RLit, 64 (2002), 257-258 (García Collado).

53-582. Vexier, M. E. (ed.) - Varia lingüistica y literaria. T. 2: Literatura: de la Edad Media al siglo XVII (N. 46-448). II BICC, 53 (1998), 404-426 (Cisneros Estupiñán). - - V. núm. 49-498.

53-583. WALde MOHENo, LiLlLAN VON DER, Concepción Company y Alrelio GonZÁLEZ (eds.) - Literatura y conocimiento medieval. Actas de las VIII Jornadas Medievales. - UNAM-UAM-EI Colegio de México, México, 2003. 518 pp. (Publicaciones de "Medievalia", 29)

\section{HISTORIA LITERARIA}

53-584. Álvarez Barrientos, JoaQlín "Nación e historia literaria a mediados del siglo XVII en España". - Historia literaria/Historia de la literatura, ed. L. Romero Tobar (Zaragoza, 2004), pp. 101-114.

53-585. Beltrán Almería, Luis - "Horizontalidad y verticalidad en la historia literaria”. - Historia literaria/Historia de la literatura, ed. L. Romero Tobar (Zaragoza, 2004), pp. 13-29.

53-586. Blecua, Alberto - "El concepto de Siglo de Oro". - Historia literaria/Historia de la literatura, ed. L. Romero Tobar (Zaragoza, 2004), pp. 115-160.

53-587. Blesa, TéA - "Leyendo en las historias géneros y estilos". - Historia literaria/Historia de la literatura, ed. L. Romero Tobar (Zaragoza, 2004), pp. 31-43.

53-588. Campos F. Fígares, Mar - "Una lectura de historias (de la literatura)". - Historia literaria/Historia de la literatura, ed. L. Romero Tobar (Zaragoza, 2004), pp. 239-252.

53-589. CHANG-RODRÍGLEZ, R. (coord.) Historia de la literatura mexicana. T. 2: La cultura letrada en la Nueva España del siglo XVII (N. 52-2061). $\| E H F, 26$ (2004), 374-377 (Álvarez Méndez). 53-590. Gies, David T. - "El reto imposible de la historia literaria: el caso Cambridge". - Historia literaria/Historia de la literatura, ed. L. Romero Tobar (Zaragoza, 2004), pp. 273-283.

53-591. Gómez Moreno, Ávgel - "Historia y canon de la literatura española medieval: 20 años de evolución y cambios". - Historia literaria/Historia de la literatura, ed. L. Romero Tobar (Zaragoza, 2004), pp. 161-175.

53-592. Mendonça Teles, Gilberto y Kiads MÜli.er-Bergh (eds.) - Vanguardia latinoamericana. Historia, crítica y documentos. T. 2: Caribe, Antillas Mayores y Menores. - Vervuert-Iberoamericana, Frankfurt/M.-Madrid, 2002. 283 pp. II Ibero, 2003, núm. 10, 219-222 (Gewecke).

53-593. NúÑez Ruiz, Gabriel - "Las historias de la literatura y la enseñanza 
pública”. - Historia literaria/Historia de la literatura, ed. L. Romero Tobar (Zaragoza, 2004), pp. 303-312.

53-594. Pedraza Jiménez, Felipe B. y Milagros Rodríguez Cáceres - Historia esencial de la literatura española e hispanoamericana. - Edaf, Madrid, 2000. II RLit, 64 (2002), 611-613 (TorresPou).

53-595. Romero Tobar, Leonardo - "La historia literaria, toda problemas". Historia literaria/Historia de la literatura, ed. L. Romero Tobar (Zaragoza, 2004), pp. 67-85.

53-596. Romero ToBar, Leonardo "Las historias literarias de los hispanistas escritores". - FGL, 2003, núms. 33/34, 197-208.

53-597. Romero Tobar, Leonardo (ed.) - Historia literaria/Historia de la literatura. - Prensas Universitarias de $\mathrm{Za}$ ragoza, Zaragoza, 2004. 472 pp. (Humanidades, 47).

53-598. Saldaña, Aifredo - "Posmodernidad, historia, literatura". - Historia literaria/Historia de la literatura, ed. L. Romero Tobar (Zaragoza, 2004), pp. 87-98.

53-599. SCHELB, HAROLD - The poem in the story: Music, poetry, and narrative. - Wisconsin University Press, Wisconsin, 2002. 316 pp. II RLitPop, 2003, núm. 2, 163-168 (Garduño Oropeza).

53-600. Soldevila Durante, I. - Historia de la novela española (1936-2000). T. 1 (N. 50-467). II RCEH, 27 (2003), 395397 (Herzberger). - V. núm. 522068.

53-601. URZAINQUI, INMACULADA - "Hacia una teoría de la historia literaria en el siglo xvin: competencias del historiador". - Historia literaria/Historia de la literatura, ed. L. Romero Tobar (Zaragoza, 2004), pp. 209-236.

V. también núm. 673.

\section{LITERATURA COMPARADA}

53-602. Aglilar, María dei. Rosario "La utilización de la Vidas paralelas de Plutarco en el Felixmarte de Hircania. A propósito de su autor, Melchor de Ortega". - BICC, 54 (1999), 289-306.
53-603. Comellas Aguirrezábal, MerceDES - "La lámpara maravillosa de Valle-Inclán y el Heinrich von Ofterdingen de Novalis o la poética como "Camino de perfección»". - RLit, 64 (2002), 121-150.

53-604. Franco Bagnouls, Lourdes "Guinos espaciales entre Santa y $\mathrm{Na}$ ná. - Santa, Santa nuestra, ed. R. Olea Franco (México, 2005), pp. 255-261.

53-605. Galmés de Fuentes, Álvaro - Romania Arabica. Estudios de literatura comparada árabe y romance. T. 2: Narrativa y farsa francesa medieval. Dante y Boccaccio. De Alfonso X el Sabio a Góngora. - Real Academia de la Historia, Madrid, 2000. 346 pp. (Clave Historial, 30). II $Z R P h, 119$ (2003), 624-629 (Kiesler).

53-606. Grande Quejigo, Francisco Javier - "La moralización ovidiana en el Libro de buen amor y la Confesión del amante". - Juan Ruiz, Arcipreste de Hita, y el "Libro de buen amor", eds. F. Toro Ceballos y B. Morros (Alcalá la Real, 2004), pp. 349-362.

53-607. JaÉn Portillo, Isabel - "Eruditos en crisis: literatura y muerte en Jorge Luis Borges y Thomas Mann". - RNo, 43 (2003), 193-198.

53-608. Leopold, Stephan - "Calderón y Kleist. Friedrich Prinz von Homburg como transposición hipertextual de $L a$ vida es sueño". — Teatro calderoniano sobre el tablado. Calderón y su puesta en escena a través de los siglos. XIII Coloquio Anglogermano sobre Calderón, Florencia, 10-14 de julio de 2002, ed. M. Tietz (Stuttgart, 2003), pp. 261-274.

53-609. Levergeois, Bertrand - "Bruno et Gracián. Corrélations”. - Baltasar Graciän: antropología y estética. Actas del II Coloquio Internacional (Berlin, 4-7 de octubre de 2001), ed. S. Neumeister (Berlin, 2004), pp. 267-279.

53-610. Locateli, Milena - "Las fallas del tiempo en El caballero de Olmedo de Lope de Vega y en Romeo and Juliet de William Shakespeare". - Criticón, 2003, núms. 87/88/89, 425-439.

53-611. Montano, Rafael - “ «El aleph»: Dante y los dos Borges". - RCEH, 27 (2003), 307-325. 
53-612. Moraies Ladrón, Marisot - Las poéticas de James Joyce y Luis MartinSantos. - P. Lang, Bern-Berlin-New York-Oxford-Wien, 2005. 336 pp.

53-613. MosQledA RIVERA, RtQlel "Dos narradores frente a la violencia: Rubem Fonseca y Francisco Hinojosa". - AEla, 38 (2004), 145-175.

53-614. Pérez-Ugena, Juto - "Muerte, piedad y memoria: Il Tuffatore de Paestum en las obras de Eugenio Montale y de José Ángel Valente". - Criticón, 2003, núms. 87/88/89, 661-678.

53-615. SAI GadDo, C. A. - From Modernism to Neobaroque. Joyce and Lezama Lima (N. 52-506). II Carav, 2002, núm. 79, 329-332 (Suárez Galbán Guerra).

\section{TEMAS LITERARIOS}

53-616. Abrahlu Haim., Naxcy - "Pools of memory: Swimming in the southern cone". - Studies in honor of Denah Lida, eds. M. G. Berg \& Lanin A. Gyurko (Potomac, Maryland, 2005), pp. 339-350.

53-617. Amar Saivchlz, Axa María - "Héroes sin honra: ética y derrota en la narrativa latinoamericana del fin del siglo xx". - Studies in honor of Denah Iida, eds. M. G. Berg \& Lanin A. Gyurko (Potomac, Maryland, 2005), pp. 382-390.

53-618. Arrovo, Jossianva - "Historias de familia: migraciones y escritura homosexual en la literatura puertorriqueña". - RCEH, 26 (2002), 361-378.

53-619. Benlisi, G, - El tema de la dictadura en la narrativa del mundo hispánico. (Siglo XX) (N. 52-2094). I Carav, 2002, núm. 79, 298-299 (Pailler).

53-620. Beltrán, Luis - La imaginación literaria. La seriedad y la risa en la literatura occidental. - Montesinos, Barcelona, 2002. 340 pp. 11 RLit, 64 (2002), 596-601 (Romo Feito).

53-621. Beltráx Almeria, Luis - "Sobre hermetismo y confesión". - RLit, 65 (2003), 533-538.

53-622. Ben-Ur Roses, Lorraine Elexa "Gonzalo Guerrero, conquistador conquistado: A case of counter-conversion in $16^{\text {th }}$ century Mexico". Studies in honor of Denah Lida, eds. M. G. Berg \& Lanin A. Gyurko (Potomac, Maryland, 2005), pp. 280-289.

53-623. Bernat Vistarini, ANtono "Imágenes y semejanzas. La dignidad del hombre en los libros de emblemas españoles". - Íns, 2003, núm. 674, 33-36.

53-624. Cíndaxo Fierro, G. - La seriedad y la risa. La comicidad en la literatura ejemplar de la Baja Edad Media (N. 50495). II ALM, 40 (2002), 423-427 (Puig). - V. núm. ว1-2221.

53-625. Canterla, Crota (coord.) - La cara oculta de la razón. Locura, creencia y utopía. - Servicio de Publicaciones, Cádiz, 2001. 422 pp. II Ibero, 2003, núm. 9, 231-233 (Checa Beltrán).

53-626. Cerda, Martha - "El secreto como fuente de poder en la literatura femenina". - TC, 2002, núm. 10, 255-261.

53-627. Cortujo Ocañ, Antonio - "La problemática sentimental y la crisis del amor cortés". - Literalura y conocimiento medieval. Actas de las VIII Jornadas Medievales, eds. L. von der Walde, C. Company y A. González (México, 2003), pp. 79-93.

53-628. Dirix, Janer - "La mística de la marginalidad: Jesusa Palancares, la Santa de Cabora y los límites de la nación en la narrativa de escritoras mexicanas contemporáneas". - $T C$, 2002, núm. 10, 225-241.

53-629. Fernatidez, L. M. - Don Juan en el cine español. Hacia una teoria de la recreación filmica (N. 49-2133). II Signos $U$, 2003, núm. 39, 238-239 (Barnaky de Proasi). - V. núm. 52-2104.

53-630. Gonzálfz del Vali.f, L. T. - La canonización del diablo. Baudelaire y la estética moderna en Fspaña (N. 51473). II RLit, 65 (2003), 314-316 (García-Abad García); Ins, 2003, núm. 682, p. 2 (Gullón). - V. núm. 52-1945.

53-631. Gravida, Migltei. Ávgei - "E1 gran milagro del hombre en el platonismo y el Renacimiento. (De Ficino y Pico a Giordano Bruno)". - Íns, 2003, núm. 674, 9-14. 
53-632. Gujarro Cebalios, Javier - "La huerta deleitosa del Libro segundo de don Clarián (1522) y otros jardines y banquetes mágicos caballerescos". BICC, 54 (1999), 239-267.

53-633. Gltiérre.7. Garcia, Santago "Personajes históricos y literarios y casuística amorosa en la lírica provenzal". - RFilR, 20 (2003), 103-119.

53-634. Levdo, Rosalbs - "El motivo de la bestia ladradora en el ciclo artúrico Post-Vulgate". - Iiterutura y conocimiento medieval. Actas de las VIII Jornadas Medievales, eds. L. von der Walde, C. Company y A. González (México, 2003), pp. 65-76.

53-635. Ll'Na Seliés, C. - La exploración de lo irracional en los escritores modernistas hispanoamericanos: literatura onírica y poetización de la realidad ( $\mathrm{N}$. 512248). II NRFH, 52 (2004); 217-219 (García Avila).

53-636. Márqlez Villanleva, Fraxcisco - Santiago: trayectoria de un mito. Edicions Bellaterra, Barcelona, 2004. 462 pp.

53-637. Marting, D. E. - The sexual woman in Latin American literature: Dangerous desires (N. 51-655). II RCEH, 27 (2003), 384-386 (Gray Díaz).

53-638. Olea Franco, Rafaei - "Imágenes francesas en la literatura mexicana del siglo xIx". - Ibero, 2003, núm. 9, $13 \check{\jmath}-145$.

53-639. Pedrosa, José Maxlei - "La mariposa, el amor y el fuego: de Petrarca y Lope a Dostoievsky y Argullol". - Criticón, 2003, núms. 87/88/89, 649-660.

53-640. Pérez-Abadín Barro, Soledad "Resonare silvas". La tradición bucólica en la poesía del siglo xv. - Universidade, Santiago de Compostela, 2004. 363 pp. (Monografias da Universidade de Santiago de Compostela, 214).

53-641. Peza Casares, Maria del Carmen - El bolero y la educación sentimental en México. - Universidad Autónoma Metropolitana-Xochimilco, México, 2001. 477 pp. II RLitPop, 2003, núm. 1, 188-197 (Negrín).

53-642. RledA, A. - Pigmalión y Galatea: refracciones modernas de un mito (N. 50 531). II $R F, 115$ (2003), 141-143
(Stauder). - V. núm. 50-1899.

53-643. SAlazar Rixcóx, JAITER - "Entre la ciencia y el sueño: notas sobre la fortuna de los cuatro elementos en las letras españolas". - RLit, 64 (2002), 319-364.

53-644. Sandartíl Bastida, Rebeca "L'n viaje por el mito del rey "Cruel»: la literatura y la historia después del Romanticismo". - RLit, 65 (2003), 59-84.

53-645. Sibbald, K. M., R. de La Fuexte y J. Dítz (eds.) - Ciudades vivas/ciudades muertas: espacios urbanos en la literatura y el folklore hispánicos. - Universitas Castillae, Valladolid, 2000. 377 pp. II RCEH, 27 (2003), 368-370 (OdarteyWellington).

53-646. Telstcher, Peter - Hombres con hombres con hombres. Männlichkeit im Spannungsfeld zwischen macho und marica in der argentinischen Erzählliteratur (1839-1999). - Edition Tranvía-Walter Frey, Berlin, 2002. 252 pp. (Gender Studies Romanistik, 8). II Ibero, 2003, núm. 12, 258-259 (Hesse).

53-647. Vega, María José - "Miseria y dignidad del hombre en el Renacimiento: de Petrarca a Pérez de Oliva”. - Íns, 2003, núm. 674, 6-9.

V. también núms. 858, 980 .

\section{GÉNEROS}

POESIA

53-648. Alfonso, Álvaro - La poesía italianista. - Eds. Laberinto, Madrid, 2002. II RLit, 65 (2003), 612-614 (Rubio Áquez).

53-649. Allllón de Haro, Pedro - La modernidad poética, la vanguardia y el creacionismo. Ed. de Javier Pérez Bazo. Universidad, Málaga, 2000.316 pp. II Ibero, 2003, núm. 9, 233-234 (Caparrós Esperante).

53-650. Balcells, José María - Ilimitada voz. (Antología de poetas españolas, 1940-2002). - Universidad, Cádiz, 2003. 456 pp. II EHF, 26 (2004), 368371 (Garnelo Merayo).

53-651. Baltista, Fraxcisco - "La tradición épica de las Enfances de Carlo 
Magno y el Cantar de Mainete perdido". - RFE, 83 (2003), 223-247.

53-652. Bonilia Cerezo, Rafael e Ignacio García Aglitar - Villancico de la Catedral de Córdoba 1682-1767. Métrica, cadencias clarines sean. - Ediciones La Posada, Córdoba, 2002. 209 pp. (Fuente de Papel, 9). II RLit, 65 (2003), 628-630 (Albalá).

53-653. Campos Moreno, Aracel. y FerNANDO NAVA -- "Un puñado de sal: poesía de un migrante queretano". - RLitPop, 2003, núm. 1, 30-51.

53-654. Cano Ballesta, J. (ed.) - Poesía española reciente (1980-2000) (N. 52556). II RCEH, 27 (2003), 598-600 (Godoy).

53-655. Ciplijauskaité, Birlté - "El exilio: camino hacia luz interior". Studies in honor of Denah Lida. eds. M. G. Berg \& Lanin A. Gyurko (Potomac, Maryland, 2005), pp. 226-235.

53-656. Correa Ramón, Amelina - Poetas andaluces en la órbita del modernismo. Diccionario. - Alfar, Sevilla, 2003. 279 pp. II RRo, 38 (2003), 175-176 (Cardwell).

53-657. Cuéllar, Donají - "Los nocturnos modernistas: esbozo de una tradición". - LMM, 13 (2002), 65-90.

53-658. Duffell, M. J. - Modern metrical theory and the "verso de arte mayor" ( $\mathrm{N}$. 48-2150). II Incipit, 20/21 (2000-01), 230-234 (Disalvo). - V. núm. 52-565.

53-659. Ferri Coll, J. M. - La poesía de la Academia de los Nocturnos (N. 522146). II RLit, 64 (2002), 268-269 (Penalva).

53-660. Floquet, ORESTE - "Unità narrativa ed unità musicale nelle cantigas di Martin Codax". - Criticón, 2003, núms. 87/88/89, 311-314.

53-661. Fröhlicher, Peter, Georges GüNter, Rita Catrina Imboden e Itzíar LóPEZ Gull (eds.) - Cien años de poesía. 72 poemas españoles del siglo XX: estructuras poéticas y pautas críticas (N. 492168). II RLit, 65 (2003), 337-339 (Hernández Durán); $R F, 115$ (2003), 399-401 (Nelting); Ibero, 2003, núm. 11, 252-254 (Pardellas Velay).

53-662. García, Miguel Ángel - "La literatura y la historia en «la otra sentimentalidad" (o cómo poner a la poesía en un compromiso)". - Íns, 2002, núms. 671/672, 16-18.

53-663. Gomis, Llorenc - "Poetas en Segovia". - Ins, 2003, núm. 684, 2-3. 53-664. Ingenschay, Dieter - "El realismo sucio o la poesía de los márgenes". Íns, 2002, núms. 671/672, 46-48.

53-665. Iravedra, Aracel - "¿Hacia una poesía útil? Versiones del compromiso para el nuevo milenio". - Íns, 2002, núms. 671/672, 28.

53-666. LanZ, JLAN JosÉ - " "Himnos del tiempo de las barricadas»: sobre el compromiso en los poetas novísimos". - Ins, 2002, núms. 671/672, 8-13.

53-667. Le Corré, H. - Poesía hispanoamericana posmodernista. Historia, teoria y prácticas (N. 49-2170). II Ibero, 2003, núm. 10, 219-222 (Gewecke). - V. núm. 52-2065.

53-668. Lorenzo Álvarez, Elena de Nuevos mundos poéticos: la poesia filosófica de la Ilustración. - Universidad-Instituto Feijoo de Estudios del Siglo XVIII, Oviedo, 2002. 573 pp. II RLit, 65 (2003), 642-645 (Checa Beltrán). 53-669. Mata Induráin, Carlos (ed.) Primavera de poemas en loor de San Francisco Javier. - Fundación Diario de Navarra, Pamplona, 2004. 221 pp. (Biblioteca Javeriana, 3).

53-670. MÉndez Rubio, ANtonio - "Otra poesía es posible. (La cuestión del sujeto y la crítica social en la poesía reciente)". - ins, 2002, núms. $671 / 672,42-45$.

53-671. Milán, Eduardo, Andrés Sánchez Robayna, José Á ygel Valente y Blanca VARELA (eds.) - Las insulas extrañas. Antología de la poesía en lengua española (1950-2000). - Galaxia GutenbergCírculo de Lectores, Barcelona, 2002. \| $B y C, 2004$, núm. 1, 92-95 (A.K.). 53-672. Ortiz Dominguez, Efrén - La rosa en fuga. - Universidad Veracruzana, Xalapa, 2002. 278 pp. II TC, 2002, núm. 1, 283-288 (López González).

53-673. Palenque, Marta - "Historia, antología, poesía: la poesía española del siglo xx en las antologías generales (1908-1941)". - Historia literaria/ Historia de la literatura, ed. L. Romero Tobar (Zaragoza, 2004), pp. 313-367. 
53-674. Paraíso, I. - La métrica española en su contexto románico (N. 50-577). II RLit, 64 (2002), 251-254 (Albalá).

53-675. Pllido Tirado, Genara - "Surgimiento y consolidación de otra poética de los setenta". - RRo, 39 (2004), 278-295.

53-676. Rodríguez, Juan Carios - "El yo poético y las perplejidades del compromiso". - Íns, 2002, núms. 671/672, 53-56.

53-677. ROMANo, MARCELA - "La canción de autor después de Franco (reflexiones críticas sobre un objeto crítico)". -Ins, 2002, núms. 671/672, 13-14.

53-678. Romero Ferrer, Alberto - "Poesía y cambio político (1789-1833)". Se hicieron literatos para ser políticos. Cultura y política en la España de Carlos $I V y$ Fernando VII, ed. J. Alvarez Barrientos (Madrid-Cádiz, 2004), pp. 167-184.

53-679. SÁnchez TORRE, LeOPOLdo - "De lo real y sus retóricas: realismo y antipoesía en las nuevas poéticas del compromiso". - Íns, 2002, núms. $671 / 672,49-53$.

53-680. Sobejano, Gonzalo - Inmanencia y trascendencia en Poesía. (De Lope de Vega a Claudio Rodriguez). - Almar, Salamanca, 2003.

53-681. Sonntag Blay, Illana L. - Twentieth-century poets from Spanish America. An index to Spanish language and bilingual anthologies. - The Scarecrow Press, Lanham-London, 1998. 701 pp. II RCEH, 26 (2002), 578-579 (Sibbald).

53-682. Toledo, AídA - "Apuntes y aproximaciones a la poesía guatemalteca actual”. - LLA, 2004, núm. 197, 53-60.

53-683. Torrente, A. y M. A. Marín Pliegos de villancicos en la British Library (Londres) y la University Library (Cambridge) (N. 51-712). II Incipit, 22 (2002), 240-242 (Altamiranda).

53-684. Uría, ISABEL - Panorama crítico del mester de clerecía. - Castalia, Madrid, 2000. 413 pp. II Incipit, 20/21 (2000-01), 189-195 (Balestrini).

53-685. Utrera Torremocha, M. V. Historia y teoría del verso libre (N. 52597). II RLit, 64 (2002), 603-605 (Luján).
53-686. Valencia Zllodga, José Néstor - "Panorámica del villancico". BICC, 53 (1998), 628-642.

53-687. Villena, Luis Aitonio - Teoria y poetas. Panorama de una generación completa en al última poesia española. 1980-2000. - Pre-Textos, Valencia, 2000. 215 pp. II Ibero, 2003, núm. 9, 239-240 (Pardellas Velay).

V. también núms. 5999, 633, 640, 856, 1017.

\section{TEATRO}

53-688. Adier, Heidrdn \& George WoOdYARD (eds.) - Widerstand und Macht. Theater in Chile. - Vervuert-Iberoamericana, Frankfurt/M.-Madrid, 2000. 201 pp. II Ibero, 2003, núm. 9, 263-265 (Floeck).

53-689. Adier, Heidruy \& María de la Luz Hurtado (eds.) - Theaterstücke aus Chile. - Vervuert, Frankfurt/M., 2000. 347 pp. II Ibero, 2003, núm. 9, 263-265 (Floeck)

53-690. Adler, Heidrun y George WoodYARD (eds.) - Resistencia y poder. Teatro en Chile. - Vervuert-Iberoamericana, Frankfurt/M.-Madrid, 2000. 186 pp. II Ibero, 2003, núm. 9, 263-265 (Floeck).

53-691. AlBERSMEIRER, F.-J. - Theater, Film, Literatur in Spanien. Literaturgeschichte als integrierte Mediengeschichte (N. 52-1892). II Ibero, 2003, núm. 9, 236-237 (Schlünder).

53-692. Ballesteros González, Avtonio y Cécile Vilvandre. de Solsa (coords.) - La estética de la transgresión. Revisiones criticas del teatro de vanguardia. Universidad de Castilla-La Mancha, Cuenca, 2000. 509 pp. II Ibero, 2003, núm. 10, 212-213 (López de Abiada). 53-693. Borja, María José - "Recursos sobre literatura y teatro áureo en internet". - EHF, 26 (2004), 253-257. 53-694. Cassol, Alesandro - "Flores en jardines de papel. Notas en torno a la colección de las Escogidas". - Criticón, 2003, núms. 87/88/89, 143-159.

53-695. Castro Caridad, Eva - "Lectura de los dramaturgos latinos en el medievo". - Íns, 2003, núm. 675, 9-12. 
53-696. Corvigo Bersal, O. - Discurso teórico y puesta en escena en los años sesenta. La encrucijada de los "realismos" (N. 50-1972). II RIit, 64 (2002), 301303 (Pérez-Bowie). - V. núm. 522175 .

53-697. Diálogo entre dos tunanles. Introd., testo e traduzione di Mauricio Fabbri. - PanEzzo Editore, Rimini, 2002. 105 pp. (Testi Inediti e Rari, 7). II RLit, 65 (2003), 635-637 (Garelli).

53-698. Daris, C. y J. E. VAREY - Actividad teatral en la región de Madrid según los protocolos de Juan García de Albertos: 1634-1660. Estudio y documentos (N. 52-2177). II Edad de Oro, 23 (2004), 463-473 (Valls-González MartínezNoguera Guirao).

53-699. Fernandes Valiadarfes, Mercfoles - "Un taller de imprenta para la Farsa llamada danca de la muerte. Burgos como foco difusor del teatro de cordel en el siglo xu”. - RFilR, 20 (2003), 7-23.

53-700. Fernández Cabezón, Rosaila "La mujer guerrera en el teatro espanol de fines del siglo xvin". - $A F F, 26$ (2003), 117-136.

53-701. Friт̌, H. у K. Рӧкп. (eds.) - Teatro contemporáneo español posfranquista. T. 2: Autores y tendencias (N. 50-1979). II Ibero, 2003, núm. 12, 236-238 (Saulheimer). - V. núm. 52-608.

53-702. Galindo, DeNa M. - "El modelo cívico del actor en la nueva comunidad nacional. Ética y estética teatral". - BICC, 53 (1998), 79-90.

53-703. Garcia Barrientos, José Llus Cómo se comenta una obra de teatro. Síntesis, Madrid, 2001. 367 pp. II RLit, 64 (2002), 249-251 (Pego Puigbó).

53-704. Garrido Camacho, P. - El tema del reconocimiento en el teatro español del siglo XV. La teoria de la anagnórisis (N. 50-1912). II RF, 115 (2003), 125-126 (Reichenberger). - V. núm. 512236.

53-705. Gonlález, Atrei.jo - "El teatro cervantino en la crítica y la escena modernas". - SLL, 5 (2003), núm. 2 , 33-50.

53-706. Govzález CaÑal, Rafael y Ubaldo Cerezo Rubio - Catálogo de comedias sueltas del fondo Entrambasaguas.
- Reichenberger, Kassel, 2000. 345 pp. II Incipit, 20/21 (2000-01), 247249 (Altamiranda).

53-707. GRahaM-Jones, J. - Exorcising History: Argentine theater under dictatorship (N. 51-731). II Ibero, 2003, núm. 10, 235-237 (Kiewert).

53-708. GLaRINo, Algcsto - "Rutas napolitanas del teatro español a finales del siglo xur. Ei caso de la Laura”. Criticón, 2003, núms. 87/88/89, 383393.

53-709. Hartwtg, StstiNe - "Teatro y sociedad en la España actual". - Ibero, 2003, núm. 12, 193-197.

53-710. INFATfes, Victor - "Liminar para un manuscrito. El Catálogo de comedias que han escrito los más célebres autores españoles". - Criticón, 2003, núms. 87/88/89, 407-413.

53-711. LaMes ObRegóx, MariNa - Teatro en Colombia, 1831-1886: práctica teatral y sociedad. - Planeta, Bogotá, 1998. 400 pp. II BICC, 53 (1998), 664-666 (López Sierra).

53-712. Maestro, Jesús G. (ed.) - Teatro hispánico y literatura enuropea. - Universidad, Vigo, 2002. $566 \mathrm{pp}$. II Ibero, 2003, núm. 11, 260-261 (Hartwig). 53-713. Marix Calyarro, Jesís Ávgfi "El entramado dialógico del discurso poético de W. Shakespeare y su adaptación al español". - $A F F, 26$ (2003), 217-232.

53-714. Nitsch, Wolfram - Barocktheater als Spietraum. - Narr, Tübingen, 2000. 216 pp. II Ibero, 2003, núm. 11, 243-244 (Escribano).

53-715. Noglfra Gutrao, Dolores "Elementos teatrales del corpus madrileño en las últimas décadas del siglo xiт". - Criticón, 2003, núms. 87/88/89, $567-576$.

53-716. Ojeda, Pedro e Irene Vallejo "El «teatro francés» de Madrid (1851-1861)". - RLit, 65 (2003), 413-446.

53-717. PAGÁx, Victor - "Un teatro para un género, un género para un teatro". - Criticón, 2003, núms. 87/88/89, 621-636.

53-718. Palacios Fernández, Emilio y Aiberto Romero Ferrer - "Teatro y política (1789-1833): entre la Revolu- 
ción Francesa y el silencio". - Se hicieron literatos para ser políticos. Cultura y politica en la España de Carlos $I V$ y Fernando VII, ed. J. Álvarez Barrientos (Madrid-Cádiz, 2004), pp. 185-242.

53-719. Pérez Magalló, J. - El teatro neoclásico (N. 50-2008). II RLit, 64 (2002), 634-638 (Checa Beltrán); RCIFH, 27 (2003), 597-598 (Haidt). -V. núm. 52-2201.

53-720. Rumírel Culrio, Tufilat I. "Ausencias de teatro". - Semiosis, 2001, núm. 7, 60-73.

53-721. Rfies Pfĩa, Marcedes de los "Vida y martirio de Santa Bárbara, una comedia inédita de la colección teatral del conde Gondomar". - Criticón, 2003, núms. 87/88/89, 745-764.

53-722. Rios Citrratalí, J. A - Cómicos ante el espejo. Los actores españoles y autobiografia (N. 51-2374). II RLit, 64 (2002), 659-663 (Bonilla Cerezo).

53-723. Romfro Ffrrer, Alberto - Calálogo de autores dramáticos andaluces. 1800-1897. T. 2. - Junta de Andalucía-Centro de Documentación de las Artes Escénicas de Andalucía, Sevilla, 2002. II RLit, 65 (2003), 645-646 (Jiménez Morales).

53-724. RubieRA, JAITLR - "La poética del espacio en la comedia barroca". Edad de Oro, 23 (2004), 279-294.

ว3-725. Rebio Jiménez, Jesís - "Primeras historias y antologías teatrales de la posguerra". - Historia literaria/Historia de la literatura, ed. L. Romero Tobar (Zaragoza, 2004), pp. 391-419. 53-726. Salazar Zagazeta, Carios Miglel. — "El teatro «evangelizador» y urbano en los Andes: encuentros y desencuentros". - Criticón, 2003, núms. 87/88/89, 775-786.

53-727. Sullington, Johx W. - Grappling with atrocity. Guatemalan theatre in que 1990s. - Fairleigh Dickinson University Press-Associated University Presses, Madison-London, 2002. 207 pp. II Ibero, 2003, núm. 12, 150151 (Gewecke).

53-728. Stllivin, H. W., R. A. Galoppe y M. L. SrotTz (eds.) - La comedia española y el teatro europeo del siglo Xim $(\mathrm{N}$. 50-2020). II $R F, 115$ (2003), 416-419 (Soons). - V. núm. ว́1-2385.
53-729. Virif. Ojedi Cilyo, Miria dei. "Los enredos de Martín «compuesta por Cepeda» y la herencia de la comedia italiana: primera aproximación". Criticón, 2003, núms. 87/88/89,589601.

53-730. Verstele, Marcot - De fusiladores y morcilleros. El discurso cómico del género chico (1870-1910). - Rodopi, Amsterdam-Atlanta, 2000. 484 pp. II Ibero, 2003, núm. 11, 249-251 (Ientzen).

53-731. Vhax Hfrrero, ANi - "Ia Tragicomedia de Polidoro y Casandrina: relación cíclica y caminos de la parodia". - Criticón, 2003, núms. 87/88/89, 899-914.

53-732. Vilches de Frltos, M. Francisca — "Teatro y memoria: la recreación del mundo rural en Las manos de José Ramón Fernández, Yolanda Pallin y Javier G. Yagüe". — RI it, 64 (2002), 235-245.

53-733. Vilchls de FrtTos, M. FrdNCisci (ed.) - Teatro y cine: la búsqueda de nuevos lenguajes expresivos. - Anales de Literatura Española y Contemporánea, Boulder, CO, 2001-02. 2 ts.: 601 pp. II RLit, 65 (2003), 270-272 (González García).

V. también núms. 840, 1017.

\section{PROSA NARRATIVA}

53-734. Aroxso, SAnros - La novela española en el fin de siglo (1975-2001). Marenostrum, Madrid, 2003. $327 \mathrm{pp}$. II EHF, 26 (2004), 371-373 (Garnelo Merayo).

53-735. Álvarez Birriextos, JohQuín "Novela, historia y política en el cambio de siglo". - Se hicieron literatos para ser políticos. Cultura y politica en la España de Carlos $N$ y Fernando VII, ed. J. Álvarez Barrientos (Madrid-Cádiz, 2004), pp. 243-270.

53-736. Artcéćs Aiddz, J. - Deus Concionator. Mundo predicado y retórica del "exemplum" en los Siglos de Oro (N. 50646). II VR, 62 (2003), 330-334 (Gómez Redondo). - V. núm. 52-2224. 53-737. Azlela Berval, María Cristiva "Máscaras, disfraces y sustituciones 
en la nouvelle medieval". - Literatura y conocimiento medieval. Actas de las VIII Jornadas Medievales, eds. L. von der Walde, C. Company y A. González (México, 2003), pp. 261-276.

53-738. Baranda, Nieves - "El dinamismo textual en la prosa de cordel: a propósito de la «Reina Sebilla...»". - BICC, 54 (1999), 268-288.

53-739. Barrero LÓPEZ, ÓSCAR - "El desengaño del naturalismo: análisis de la evolución de algunos novelistas españoles del siglo XIX". - RLit, 64 (2002), 63-92.

53-740. Bognolo, A. - La finzione rinnovata: meraviglioso, corte e avventura nel romanzoi cavalleresco del primo Cinquecento spagnolo (N. 47-1840). II BICC, 54 (1999), $307-315$ (Lucía Megías).

53-741. Cabo Aseguinolaza, Fernando "El entimema y el estilo de la picaresca". - Edad de Oro, 23 (2004), 231-247.

53-742. CaIderón, Mario et al. - Cuento y mortaja. (La ficción en México). Ed., pról. y notas de Alfredo Pavón. UAT-INBA-CONACULTA, Tlaxcala, 2001. 246 pp. II TC, 2002, núm. 10, 289-293 (Muñoz Martínez).

53-743. Campbell, Ysla - "La literatura picaresca del siglo XVII ¿una narrativa reformista?". - NRFH, 52 (2004), 153-171.

53-744. Carrasco Urgomi, Maria Soledad, Francisco López Estrada y FÉlix Carras$\mathrm{CO}$ - La novela española en el siglo xV. Vervuert-Iberoamericana, Frankfurt/M.-Madrid, 2001. 294 pp. II RFLL, 22 (2004), 351-353 (Sánchez Laílla).

53-745. Casamayor Cisneros, Odette "Incertidumbre resplandeciente. Breve incursión en la narrativa escrita durante la década del 90 en la Isla de Cuba”. - Carav, 2002, núm. 78, 179-196.

53-746. Charnon-Deltsch, L. - Fictions of the feminine in the nineteenth-century Spanish press (N. 49-2222). II RLit, 64 (2002), 643-647 (Sánchez Llama). V. núm. 51-439.

53-747. Chicote, Gloria B. - "Configuración discursiva de la materia artúrica en la prosa castellana: el ms. 9611 de la Biblioteca Nacional de Madrid". - $\mathrm{Li}$ teratura y conocimiento medieval. Actas de las VIII Jornadas Medievales, eds. L. von der Walde, C. Company y A. González (México, 2003), pp. 51-63.

53-748. Cluff, Russell M., Alfredo PAvón, Luis Arturo Ramos y Guillermo SAMPERIO (sel.) - Cuento mexicano moderno. Pról. de Alfredo Pavón. UNAM-Universidad Veracruzana-Aldus, México, 2000. 829 pp. II TC, 2002, núm. 10, 293-296 (Cervantes).

53-749. Corfis, I. A. (ed.) - "La historia de los nobles caualleros Oliveros de Castilla y Artus d'Algarve". From Romance to Chapbook. The making of a tradition (N. 47-508). II Incipit, 22 (2002), 238-240 (Ferro).

53-750. Cortijo OCAÑa, ANTONIO - La evolución genérica de la ficción sentimental de los siglos XV y XVI. Género literario y contexto social. - Tamesis, London, 2000. 335 pp. II RFE, 83 (2003), 181-186 (Gómez Ramírez); RLit, 65 (2003), 614 617 (Sanmartín Bastida).

53-751. Cortínez, V. (ed.) - Albricia: la novela chilena de fin de siglo (N. 51781). II RCEH, 27 (2003), 357-359 (Holmes).

53-752. Díaz Navarro, Epicteto y José RAMÓN GONZÁLEZ - El cuento español en el siglo $\mathrm{XX}$. - Alianza, Madrid, 2002. 232 pp. II RCEH, 27 (2003), 573-575 (Percival).

53-753. Diaz Urrutia, Ángel - Cruzados de novela: las novelas de la guerra cristera. - EUNSA, Pamplona, 2002. 246 pp. II LMM, 14 (2003), 233-235 (Mosqueda Rivera).

53-754. Fernández Utrera, M. S. - Visiones de estereoscopio. Paradigma de hibridación en el arte y la narrativa de la vanguardia española (N. 52-2241). II RCEH, 27 (2003), 580-581 (Fuente Ballesteros).

53-755. Garcí, Gustavo V. - La literatura testimonial latinoamericana. (Re)presentación y (auto)construcción del sujeto subalterno. - Pliegos, Madrid, 2003. 278 pp. (Pliegos de Ensayo, 173).

53-756. García Gual, Carios - Apología de la novela histórica y otros ensayos. Península, Barcelona, 2002. 174 pp. II $E H F$, 26 (2004), 366-368 (Garnelo Merayo).

53-757. Gómez-Martínez, José Luis "Contextualización de la teología de 
la liberación en la narrativa iberoamericana". - Semiosis, 2001, núm. 7, 88-103.

53-758. Hafter, Monroe Z. - "Witinia's letters (1822) as Romantic novel and critique of the Spanish mindset". Studies in honor of Denah Lida, eds. M. G. Berg \& Lanin A. Gyurko (Potomac, Maryland, 2005), pp. 144-155.

53-759. Hertel-Mesenhöller, Heike Das Bild der Frau im Spanischen Roman des 18. Jarhunders. Im Spannungsfeld von Lebenswirklichkeit unf Fiktion. - Vervuert, Frankfurt/M., 2001. 239 pp. II $R F, 115$ (2003), 265-267 (Chihaia).

53-760. HolzMAN, Gabriela - Schaulust und Verbrechen. Eine Geschichte des Krimis als Mediengeschichte (1850-1950). - Metzler, Stuttgart-Weimar, 2001. 357 pp. Il Ibero, 2003, núm. 10, 222226 (Buschmann).

53-761. Lagmavovich, David - "Perfil de la narrativa policial rioplatense". Semiosis, 2001 , núm. 7, 46-う8.

53-762. I ANDEIRA, R. - El género policíaco en la literatura española del siglo XIX (N. 50-675). II RCEH, 27 (2003), 588-590 (Bly); Ibero, 2003, núm. 11, 247-249 (Peters).

53-763. López Ropero, M. Lolrdes - The Anglo-Caribbean migration novel: Writing from the diaspora. - Universidad, Alicante, 2004. $215 \mathrm{pp}$.

53-764. Lucia Mecias, J. M. (ed.) - Antologia de los libros de caballerias castellanos (N. 50-2054). II Inicpit, 22 (2002), 232-237 (Rodríguez Alemán).

53-765. Llicía Megías, José Maxlei. "Catálogo descriptivo de libros de caballerías castellanos. XII. Tercera parte de Florambel de Lucea: un texto recuperado, una historia por descubrir ". BICC, 54 (1999), 33-75.

53-766. MataMoro, BLAS - Puesto fronterizo. Estudios sobre la novela familiar del escritor. - Síntesis, Madrid, 2003. 302 pp. II Íns, 2003, núm. 683, 9-10 (Roffé).

53-767. Molero de la Iglesia, A. - La autoficción en España. Jorge Semprún, Carlos Barral, Luis Goytisolo, Enriqueta Antolín y Antonio Muñoz Molina (N. 49-867). II RLit, 64 (2002), 304305 (Bartolomé Porcar). - V. núm. ว2-682.
53-768. Mollejo, A. - El cuento español de 1970 a 2000. Cuatro escritores de Madrid: Francisco Umbral, Rosa Montero, Almudena Grandes y Javier Marias (N. 51-814). II Ibero, 2003, núm. 12, 235236 (Schwenzfeier-Brohm).

53-769. Moral es SÁnchez, I. - La novela como género. Tradición y renovación en la teoría literaria española del siglo XIX (N. 51-815). II RLit, 64 (2002), 290-292 (Coca Ramírez). - V. núm. 52-684.

53-770. Nava, Marisol - "Obsesiones sagradas". - TC, 2002, núm. 10, 281284.

53-771. Parrilia, Carmen - "La ficción sentimental y sus lectores". - Íns, 2003, núm. 675, 21-24.

53-772. Pavón, Alfredo - Al final, reCuento. T. 1: Orígenes del cuento mexicano: 1814-1837. - UAM-Benemérita Universidad Autónoma de Puebla, México, 2004. 514 pp. (Biblioteca de Signos, 32).

53-773. Pavón, Alfredo - Ojo insomne. - CONACULTA-Instituto Veracruzano de Cultura, México, 1999. 135 pp. II TC, 2003, núm. 12, 179-190 (Berbal Arana).

53-774. Pavós, Al FREDo - "Orígenes del cuento mexicano". - TC, 2003, núm. 12, 129-141.

53-775. Pavón, Alfredo (ed.) - Cuento bueno, hijo ajeno. (La ficción en México). - UAT-INBA-CONACULTA-ITC, Tlaxcala, 2002. 232 pp. II TC, 2003, núm. 12, 190-194 (Pérez).

53-776. Ponce, N. - Diagonales del género. Estudios sobre el policial argentino (N. 52-2276). II Ibero, 2003, núm. 10, 222 226 (Buschmannn).

53-777. Pöppel, Hubert - La novela policíaca en Colombia. - Universidad de Antioquia, Medellín, 2001. 353 pp. II Ibero, 2003, núm. 10, 222-226 (Buschmann).

53-778. Prendes, M. - La novela naturalista hispanoamericana. Evolución y di recciones de un proceso narrativo $(\mathrm{N}$. 52-689). II NRFH, 52 (2004), 213-216 (Rodríguez González).

53-779. RAMOS, RAFAEL - "Lectura y lectores de relatos de caballerías en la Castilla medieval". - Ins, 2003, núm. $675,24-27$. 
53-780. Rebollo Ávalos, M. José - "El elemento árabe en la narrativa espanola contemporánea: Tuareg". $A E F, 26$ (2003), 355-367.

53-781. Ródenas de Moya, D. - Los espejos del novelista: modernismo y autorreferencia en la narrativa vanguardista española (N. 48-730). II RCEH, 26 (2002), 575-578 (Schulman). - V. núm. 50-693.

53-782. Rodríglez Gutiérrez, Borja "Los cuentos de la prensa romántica española (1830-1850): clasificación temática". - I, 2003, núm. 57, 1-26.

53-783. Saint-Lambert, J.-F. DE - Colección de cuentos morales (los da a la luz Francisco de Tójar), ed. e introd. J. Álvarez Barrientos (N. 51-829). II RLit, 65 (2003), 300-305 (Bonilla Cerezo).

53-784. Sales Dasí, Emillo J. - " "Ver» y "mirar» en los libros de caballerías". - BICC, 54 (1999), 1-32.

53-785. Sandoval, Adrlana - "Lammenais y la novela social mexicana del siglo xix: un primer acercamiento". LMM, 14 (2003), 43-61.

53-786. Sarlo, Beatriz - El imperio de los sentimientos. - Norma, Buenos Aires, 2004. 232 pp. II Alpha, 2004, núm. 20, 295-296 (Barraza Toledo).

53-787. Servén Díez, Carmen - "La Ilustración Católica frente a la novela: 1877 1894". - RLit, 64 (2002), 219-234.

53-788. Shaw, Donald L. - A companion to modern Spanish American fiction. Tamesis, London, 2002. 258 pp. II Ibero, 2003, núm. 12, 243-244 (Spiller).

53-789. Stldemund-Halévy, Michael "Mateo $i$ Odoskia. Lectura sobre una novela y un refranero sefardí desconocidos". - RGG, 10 (2004), 55-81.

53-790. Villalba Álvakez, M. (ed.) Mujeres novelistas en el panorama literario del siglo Xx. Ier Congreso de Narrativa Española (en lengua castellana) (N. 51838). Il Ibero, 2003, núm. 12, 228-229 (Buck).

53-791. Villanleva, Nery Rolando Grandes novelas españolas contemporáneas y su versión cinematográfica. Pliegos, Madrid, 2001. 176 pp. (Pliegos de Ensayo, 153).

53-792. Wright, Diane M. - "La construcción del sujeto femenino en la novela sentimental del siglo xv: la voz como punto de resistencia". - Literatura y conocimiento medieval. Actas de las VIII Jormadas Medievales, eds. L. von der Walde, C. Company y A. González (México, 2003), pp. 95-108.

53-793. Zavala, Lauro - "El cuento ultracorto bajo el miscroscopio". RLit, 64 (2002), 539-553.

53-794. ZaVala, LaURo - Paseos por el cuento mexicano contemporáneo. - Nueva Imagen, México, 2004. $258 \mathrm{pp}$.

V. también núms. 599, 600, 619, 858.

\section{OTROS GÉNEROS EN PROSA}

53-795. Altuna, E. - El discurso colonialista de los caminantes. Siglos XVII-XVIII (N. 51-846). II Ibero, 2003, núm. 10, 217-219 (Tieffemberg).

53-796. Álvarez, Alexandra y EnriQle Obediente - "Análisis de un documento colonial americano: la carta de Agostino a su mujer". - I, 2003, núm. 57, 64-79.

53-797. Bencomo, Anadeli - "Subjetividades urbanas: mirar/contar la urbe desde la crónica". - Ibero, 2003, núm. 11, 145-159.

53-798. Casas Rigali, JUan - "Libros y lectura de la realidad en los viajes medievales". - Íns, 2003, núm. 675, 27-28.

53-799. Cátedra, Pedro M. (ed.) - Los sermones en romance del manuscrito 40 (siglo xv) de la Real Colegiata de San Isidoro de León: edición y estudio. - SEMyR, Salamanca, 2002. II RLit, 65 (2003), 610612 (Sanmartín Bastida).

53-800. Chacón, H. - Tractado de cauallería de la gineta, ed. N. Fallows (N. ว02093). II Incipit, 20/21 (2000-01), 235-237 (Janin).

53-801. Colombi, BeatrIz - "Retóricas del viaje a España, 1800-1900". - Ibero, 2003, núm. 9, 129-133.

53-802. Conte, DAvid - "Las tres Gracias. (Apunte sobre el género intermedio)". - Íns, 2003, núm. 673, 13-16. 53-803. Croguennec-Massol, Gabrielle - "Le costumbrismo portoricain et l'esclavage. Un article de 1874". Carav, 2003, núm. 81, 287-291. 
53-804. Dérín López, FerNando - " "Entrar dentro de sí mismos»: la crisis del Antiguo Régimen en las autobiografías de sus protagonistas". - Se hicieron literatos para ser politicos. Cultura y politica en la España de Carlos IV y Fernando VII, ed. J. Álvarez Barrientos (Madrid-Cádiz, 2004), pp. 331-372.

53-805. Elu.is, Robert R. - They dream not of angels but of men: Homoeroticism, gender, and race in Latin American autobiography. - University Press of Florida, Gainesville, 2002. 220 pp. II RCEH, 27 (2003), 578-580 (Schaefer).

53-806. Flentes, Jcan Héctor - "La Doctrina del bienauenturado Bernaldo Santo: el manuscrito escurialense S.II.14". - Incipit, 22 (2002), 195-206.

53-807. FlNes, LeONARdo - "El encuentro de la historia y de la ley en el discurso cronístico post-alfonsí". - Literatura y conocimiento medieval. Actas de las VIII Jornadas Medievales, eds. L. von der Walde, C. Company y A. González (México, 2003), pp. 393-404.

53-808. Cléa Ginés, Isabel - "El De contemptu mundi de Inocencio III y la miseria de la condición humana". ins, 2003, núm. 674, 3-6.

53-809. Gómez Moreno, Ángel - "La hagiografia, clave poética para la ficción literaria entre medioevo y barroco (con no pocos apuntes cervantinos)". - Edad de Oro, 23 (2004), 249-277.

53-810. Guevara B., J. César y J. Rafael Martínez E. - "El movimiento de los cuerpos graves en La nueva ciencia de Nicolò Tartaglia”. - Literatura y conocimiento medieval. Actas de las VIII Jornadas Medievales, eds. L. von der Walde, C. Company y A. González (México, 2003), pp. 503-518.

53-811. Holvenaghel, Elgenla - "La hegemonia de la temática sobre la forma en el estudio del ensayo hispanoamericano". - RLit, 64 (2002), 525-537.

53-812. KoHLT, Karl - "La ficción de la crónica y la verdad de la épica". - I $I$, 2003, núm. 58, 1-8.
53-813. LI, A. DE - Repertorio de los tiempos, ed. L. Delbrugge (N. 52-721). II $Z R P h, 119$ (2003), p. 782 (Lebsanft). - V. núm. 52-2321.

53-814. Llama Sáxchez, Ínigo (ed.) Antología de la prensa periódica escrita por mujeres (1843-1894). - Universidad, Cádiz, 2001. 315 pp. II RCEH, 27 (2003), 561-563 (Bieder).

53-815. Martínez, St'saxa S. - "Let's go! Touring gringo/a identities in travel narratives to Guatemala”. - Brújula, 3 (2004), núm. 1, 84-100.

53-816. Mlrillo Gallegos, Verónica "Fuentes medievales de un confesionario novohispano del siglo xи". Literatura y conocimiento medieval. Actas de las VIII Jornadas Medievales, eds. L. von der Walde, C. Company y A. González (México, 2003), pp. 329342.

53-817. Ofer, InBaL - "Fragmented autobiographies: A style of writing or self-perception? The case of Pilar Primo de Rivera". - Ibero, 2003, núm. 9, 37-51.

53-818. Palacios Fervández, Emillo y Aiberto González Troyano - "La pluralidad y la polémica: ensayistas y políticos de 1789 a 1833 ". - Se hicieron literatos para ser politicos. Cultura y política en la España de Carlos $I V$ y Fernando VII, ed. J. Álvarez Barrientos (Madrid-Cádiz, 2004), pp. 271-329.

53-819. Pierint, Margarita - "Un viajero austriaco en México. Los Recuerdos de Isidore Löwensten (1838)". - LMM, 14 (2003), 7-12.

53-820. Pontón, Gonzalo - "Mensajerías y colecciones: la lectura de las cartas en el siglo xv". - Íns, 2003, núm. 675, 29-31.

53-821. Río Parra, Elf.xa del - "Eslabones perdidos: unas notas sobre prensa científica y espectáculo en el siglo xix transatlántico". - Ibero, 2003 , núm. 9, 161-170.

53-822. Roldi., JEAX - La tradition d'écriture des "Flores de Derecho": réalisation de vingt-deux scripteurs. Propos atribué à Jacobo de Junla, el de las leyes. - Klincksieck, Paris, 2000-2002. 3 ts.: 492, 388 , 360 pp. II RFE, 83 (2003), 336-341 (García Martín). 
53-823. Sánchez Hita, Beatriz - "Cartillas políticas y catecismos constitucionales en el Cádiz de las Cortes: un género viejo para la creación de una nueva sociedad". - RLit, 65 (2003), 541-574.

53-824. Toriosa, V. - Escrituras ensimismadas: la autobiografía en la democracia española (N. 50-719). II RLit, 65 (2003), 325-328 (Bartolomé Porcar).

53-825. Trigo, ABrIL - Memorias migrantes. Testimonios y ensayos sobre la diáspora unuguaya. - Beatriz Viterbo, Rosario, 2003. II EUSB, 2003-04, núms. 22/23, 389-406 (Laera).

53-826. Vallejos, Patricla - "Contribución a la historia del discurso científico en la Argentina: etapas de la estandarización del artículo experimental en el primer tercio del siglo xix". - ALHis, 17/18 (2001-02), 203-219.

53-827. Wasserman, Fabio - “"Las prendas jeniales de nuestra sociedad»: representaciones del pasado $\mathrm{e}$ identidad nacional en el discurso de las élites político-letradas chilenas (1840-1860)". — Ibero, 2003, núm. 9, $7-26$.

53-828. Weidenbusch, Waltraud - "Denominaciones en el reino natural en crónicas del siglo xvı". - Historia del léxico español. Enfoques y aplicaciones. Homenaje a Bodo Müller, eds. J. Lüdtke y C. Schmitt (Frankfurt/M.-Madrid, 2004), pp. 265-284.

V. también núm. 722.

\section{LITERATURA TRADICIONAL Y POPULAR}

53-829. Abascal, M. Dolorfs - La teoría de la oralidad. - Universidad, Málaga, 2004. 247 pp. (Anejos de "Analecta Malacitana", 49).

53-830. Albalá, Paloma - "Sobre la pastorela: a propósito de una canción navideña española en las Islas Marianas". - RLit, 64 (2002), 365-384.

53-831. BazÁx Bonfll, Rodrigo - "Realismo, violencia y horror en el Romancero Viejo: inicio de una tradición temática y evolución de su tratamiento". - Literatura y conoci- miento medieval. Actas de las VIII Jornadas Medievales, eds. L. von der Walde, C. Company y A. González (México, 2003), pp. 131-148.

53-832. Beltrán, R. (ed.) - Historia, reescritura y pervivencia del Romancero. Estudios en memoria de Amelia García Valdecasas (N. 51-575). II Ibero, 2003, núm. 10, 194-195 (Diaconu).

53-833. Beltráx, Vicenc - "Los usuarios de los cancioneros". - Íns, 2003, núm. 675, 19-20.

53-834. Bokus, Bärara - Niños que cuentan cuentos a oyentes de menor y de mayor edad: diferencias en la orientación del narrador". - BLin, 2003, núm. 20, 4-21.

53-835. Botta, Patrizia - "Las fiestas de Zaragoza y las relaciones entre LB1 y 16 RE”. - Incipit, 22 (2002), 13-31.

53-836. Blenrostro Nava, Ari.ahé "Tres narraciones sobre naguales de Tlaxcala". - RLitPop, 2003, núm. 2, 45-52.

53-837. Cañas Mcrillo, Jesćs - "La renegada penitente". - $A E F, 26$ (2003), 31-42.

53-838. Cid, Jestis Antonio (ed.) - Silva asturiana I. Primeras noticias y colecciones de romances en el s. XIX. - Universidad Complutense de Madrid, Madrid, 1999. II Incipit, 22 (2002), 173-186 (Chicote).

53-839. Conde, Juan Carlos - "LB1: hacia la historia del códice". - Incipit, 22 (2002), 33-51.

53-840. Cortés Hernández, Saytuago "Vida de san Albano: herencia del teatro del Siglo de Oro en los pliegos de cordel". - RLitPop, 2003, núm. 2, 73-91.

53-841. Díaz, JoAQLín - "Literatura de cordel: pliegos, aleluyas". - Se hicieron literatos para ser políticos. Cultura y política en la España de Carlos $I V$ y Fernando VII, ed. J. Álvarez Barrientos (Madrid-Cádiz, 2004), pp. 63-82.

53-842. Díaz G. Viana, L. (coord.) - Palabras para el pueblo. T. 1: Aproximación general a la literatura de cordel. T. 2: La colección de pliegos del CSIC: fondos de la imprenta Hernando (N. 52-737). II RLit, 65 (2003), 273-274 (Carda Collado). 
53-843. Flores, EnriQue - "La destrucción de Jerusalén: fantasma, violencia y conquista en un libro de cordel del siglo xv". - RLitPop, 2003, núm. 1, 67-86.

53-844. González, Atrelio - "El modelo del caballero: de la épica al Romancero". - Literatura y conocimiento medieval. Actas de las VIII Jornadas Medievales, eds. L. von der Walde, C. Company y A. González (México, 2003), pp. 121-130.

53-845. González, Raúl Eduardo - $E l$ valonal de la Tierra Caliente. - Jitanjáfora-Red Utopía, Morelia, 2002. 91 pp. II RLitPop, 2003, núm. 1, 163-169 (Sánchez).

53-846. Hlerta Calvo, Javier, Emilio Peral Vega y Jesús Ponce Cárdenas (eds.) - Tiempo de burlas. En torno a la literatura burlesca del Siglo de Oro. Verbum, Madrid, 2001. 250 pp. II RLit, 64 (2002), 627-630 (Bonilla Cerezo).

53-847. Johansson K., Patrick - "Cuecuechcuicatl, «Canto travieso»: una antecedente ritual prehispánico del albur mexicano". - LMM, 13 (2002), 7-48.

53-848. LACARRA LANZ, EUKENE - "El otro lado de la virginidad conventual: edición, anotación y traducción de un maldit anónimo". - Criticón, 2003, núms. 87/88/89, 415-424.

53-849. Lienhard, Martin (ed.) - La memoria popular y sus transformaciones/A memória popular $e$ as suas transformações. América Latina y /e paises luso-africanos. - Vervuert-Iberomericana, Frankfurt/M.-Madrid, 2000. 302 pp. II Ibero, 2003, núm. 9, 248-249 (Gringberg Pla).

53-850. Lobato Osorio, Lucila - "Chalino Sánchez: corrido de personaje”. - RLitPop, 2003, núm. 1, 87-116.

53-851. LóPEz-BARALT, LuCE - "En busca de un profeta perdido: el viaje maravilloso de Buluquiya a los confines del universo en una leyenda aljamiada del siglo xv". - Studies in honor of Denah Lida, eds. M. G. Berg \& Lanin A. Gyurko (Potomac, Maryland, 2005), pp. 56-70.
53-852. Mariscal HaY, Beatriz - "La verdad del juglar: observaciones sobre la Chanson de Saisnes". - Literatura y conocimiento medieval. Actas de las VIII Jornadas Medievales, eds. L. von der Walde, C. Company y A. González (México, 2003), pp. 111-119.

53-853. Masera, Mariana - "La cultura popular en la Inquisición: siete textos novohispanos del siglo xur". - RLitPop, 2003, núm. 2, 5-33.

53-854. Mil.tet, V. - Épica germánica y tradiciones épicas hispánicas: Waltherius y Gaiferos. La leyenda de Walther de Aquitania y su relación con el romance de Gaiferos (N. 49-727). II Incipit, 20/21 (2000-01), 185-189 (Tenenbaum).

53-855. Nava, Gabriela — " "Pongan cuidado, muchachas, miren cómo van viviendo". Los feminicidios en los corridos, ecos de una violencia censora”. - RLitPop, 2003, núm. 2, 124-140.

53-856. Palenque, Marta - La poesía en las colecciones de literatura popular: "Los poetas" (1920 y 1928) y "Romances" (s.f.). - CSIC, Madrid, 2001. 222 pp. + CD II RLit, 64 (2002), 653-656 (Alarcón Sierra).

53-857. Posada, Consuelo - "La décima cantada en el Caribe y la fuerza de los procesos de identidad". - RlitPop, 2003, núm. 2, 141-154.

53-858. Ronkíguez Valle, Nieves - "Cinco relatos sobre el coyote". - RLitPop, 2003, núm. 1, 17-29.

53-859. Salazar, Flor - El Romancero Vulgar y Nuevo. Pres. e introd. de Diego Catalán. - Universidad Complutense, Madrid, 1999. II Incipit, 22 (2002), 173-186 (Chicote).

53-860. Sánchez, Rosa Virginia - "La voz de un repentista cubano". - RLitPop, 2003, núm. 2, 53-70.

53-861. SAntis, Francesca de - "Pastorcico nuevo, de color de [¿azor?]". Criticón, 2003, núms. 87/88/89, 227237.

53-862. Weich-ShaHAK, S. - Repertorio tradicional infantil sefardi. Retahilas, juegos, canciones y romances de la tradición oral, est. crít. A. Pelegrín (N. 51-916). II RLitPop, 2003, núm. 1, 155-163 (Negrín). - V. núm. 51-2473. 
AUTORES (Y OBRAS ANÓNIMAS)

\section{EDAD MEDIA}

\section{Alfonso Xel Sabio}

53-863. Fervández-Ordóñez, I. - Alfonso $X$ el Sabio y las Crónicas de España (N. 50-785). II VR, 62 (2003), 328-330 (Hilty). - V. núm. 52-2360.

53-864. Higashi, Alejandro - "Tipología y valor de la divisio textus en las obras del taller alfonsí". - Literatura y conocimiento medieval. Actas de las VIII Jornadas Medievales, eds. $\mathrm{L}$. von der Walde, C. Company y A. González (México, 2003), pp. 405-440.

53-865. Lebsanft, Franz - "Historia de las ideas, historia de las palabras, antropología lingüística. Imaginación y fantasía en las Siete Partidas y otros textos medievales españoles". - Historia del léxico español. Enfoques y aplicaciones. Homenaje a Bodo Müller, eds. J. Lüdtke y C. Schmitt (Frankfurt/M.Madrid, 2004), pp. 39-60.

53-866. MARTIN, G. (ed.) - La historia alfonsí: el modelo y sus destinos (siglos XIIXV) (N. 51-922). II Incipit, 20/21 (2000-01), 195-201 (Funes).

53-867. Montoya Martínez, Jesús - Composición, estructura y contenido del Cancionero Marial de Alfonso X. - Real Academia Alfonso el Sabio, Murcia, 1999. II Incipit, 20/21 (2000-01), 202206 (del Río).

53-868. PAREDES, JCAN - El cancionero profano de Alfonso X el Sabio. - Japadre Editore-L'Aquila, Roma, 2001. 465 pp. II Incipit, 22 (2002), 220-222 (del Río).

53-869. Paredes, J. - Las cantigas de escarnio y maldecir de Alfonso $X$ : problemas de interpretación y crítica textual (N. 482416). II Incipit, 20/21 (2000-01), 207-209 (del Río).

53-870. Parkinson, S. (ed.) - Cobras e Son. Papers on the text, music and manuscripts of the "Cantigas de Santa Maria” (N. 51-2479). " Z ZRPh, 119 (2003), 688-689 (Gier). - V. núm. 52-766.

53-871. Sánchez, M. Nieves (dir.) - Diccionario español de documentos alfonsies.
- Arco-Libros, Madrid, 2000. 461 pp. II RLit, 65 (2001), 259-261 (Colón).

V. también núm. 894.

\section{Amadis de Gaula}

53-872. Mérida Jiménez, Rafael Manuei. - "Fuera de la orden de natura": magias, milagros y maravillas en el "Amadís de Gaula". - Reichenberger, Kassel, 2001. II RFE, 83 (2003), 328-332 (Rodríguez Alemán).

53-873. MÉRIdA JimÉNez, Rafael M. "Las historias fingidas de Garci Rodríguez de Montalvo". - BICC, 54 (1999), 180-216.

53-874. Muñoz, Sánchez, Juan Ramón "El Amadís de Gaula como posible fuente de La Galatea". - NRFH, 52 (2004), 29-44.

53-875. Suárez Pallasá, Aquilino - "El Evangelio apócrifo de Nicodemo y el Amadis de Gaula de Garci Rodríguez de Montalvo". - Incipit, 22 (2002), 158-172.

\section{Baena, Juan Alfonso de}

53-876. Serrano Reyes, Jesús Luis y Juan FERNÁNdEZ JimÉxez (eds.) - Juan Alfonso de Baena y su "Cancionero". Actas del I Congreso Internacional sobre el "Cancionero de Baena" (Baena, del 16 al 20 de febrero de 1999). - Ayuntamiento de Baena-Diputación de Córdoba, Baena, 2001. 474 pp. II RFE, 83 (2003), 207211 (Perea Rodríguez).

\section{Berceo, Gonzalo de}

53-877. BLrkaRd, RichaRd - "Berceo's limited dogmata concerning the Virgin in his Milagros de Nuestra Señora". - RNo, 44 (2004), 227-233.

53-878. Montoya Martínez, Jesús - "El "Milagro literario" en Berceo a la luz de la retórica cristiana". - Incipit, 20/21 (2000-01), 13-42. 


\section{Cancioneros}

53-879. Cátedra, P. - Poesía de pasión en la Edad Media. El "Cancionero" de Pero Gómez de Ferrol (N. 52-2370). II RLit, 65 (2003), 279-282 (Rodríguez-Velasco).

53-880. McPherson, I. - The invenciones y letras of the "Cancionero General" (N. 47-1921). II Incipit, 20/21 (2000-01), 226-230 (Tenenbaum).

53-881. Rubio Márquez, Marcial - El cancionero de Juan de Escobedo. (Ms. $330 \mathrm{Bi}$ blioteca Real Academia Española). Edición y estudio. - Edizioni Ets, Pisa, 2004. 450 pp. (Biblioteca Studi Ispanici, 8).

\section{Cartagena, Teresa de}

53-882. Moore, JoHN K. JR. - "Conventional botany or unorthodox organics?: On the meollo/ corteza metaphor in Admiraçión operum Dey of Teresa de Cartagena". - RNo, 44 (2003), 3-12. 53-883. Rose, Constance - "Teresa de Cartagena and the uncircumcised ear". - Studies in honor of Denah Lida, eds. M. G. Berg \& Lanin A. Gyurko (Potomac, Maryland, 2005), pp. 84-95.

Castigos e documentos para bien vivir ordenados por el rey don Sancho $I V$

53-884. Bizarri, Hugo O. - "Del texto a la imagen: representaciones iconográficas de la realeza en un manuscrito de los Castigos del rey don Sancho IV (ms. BNMadrid 3995)". - Incipit, 22 (2002), 53-94

\section{Corral, Pedro del}

53-885. Corral, P. DE - Crónica del rey don Rodrigo, postrimero de los godos. (Crónica sarracina), ed. J. D. Fogelquist (N. 52-779). II RCEH, 27 (2003), 373-374 (Agnew)

\section{Dança de la muerte}

Diálogo entre el prudente rey y el sabio aldeano

53-886. Gómez Sierra, E. (ed.) - Diálogo entre el prudente Rey y el sabio aldeano (olim "Libro de los pensamientos variables") (N. 50-835). II Incipit, 22 (2002), 229-231 (Rosende).

\section{Diaz de Fregenal, Vasco}

53-887. Calderón, Carlos - "La supuesta obra literaria de Vasco Díaz Tanco de Frexenal o 96 textos en busca de autor (Orense, ca. 1550)". - ALM, 40 (2002), 377-389.

\section{Enriquez del Castillo, Diego}

53-888. Bizarri, Hugo O. - "Crónica de Enrique IV de Diego Enríquez del Castillo: el manuscrito de la MartinLuther-Universität Halle-Wittenberg". - Incipit, 20/21 (2000-01), 133-142.

53-889. Olivetto, Georgina - "Crónica de Enrique $I V$ de Diego Enríquez del Castillo: el manuscrito de la colección Foulché-Delbosc conservado en la Biblioteca Nacional Argentina". Incipit, 20/21 (2000-01), 143-151.

\section{García de Salazar, Lope}

53-890. Avenoza, Gemma - "Algunos libros de la biblioteca de Lope García de Salazar". - RFE, 83 (2003), 5-37.

\section{Historia troyana}

53-891. Chinchilla, P. de - Libro de la historia troyana, ed. M. D. Peláez de Benítez (N. 49-2299). II Incipit, 20/21 (2000-01), 220-226 (González).

V. también núm. 916.

\section{Las mocedades de Rodrigo}

53-892. Bailey, Matthe (ed.) - Las Mocedades de Rodrigo: estudios críticos, ma- 
nuscrito y edición. - King's College London Centre for Late Antique \& Medieval Studies, London, 1999. II Incipit, 20/21 (2000-01), 119-132 (Funes).

53-893. ZaderenKo, Irene - "Rodrigo en las Mocedades: ¿vasallo leal o joven rebelde?". - RFE, 83 (2003), 261-279.

\section{Libro de Alexandre}

53-894. Calderón Calderón, Manuel "Alexandre, Apolonio y Alfonso X". - Incipit, 20/21 (2000-01), 43-64.

53-895. JANIN, ÉrICA - "Estructura arbórea y función de las descripciones del mundo en el Libro de Alexandre". Incipit, 20/21 (2000-01), 65-79.

53-896. Nelson, Dana A. - "El Libro de Alexandre. en marcha hacia el original". - RFE, 83 (2003), 63-92.

53-897. PaCheco, LoRena Edith y GloRia EDITH SiRacusa - "El narrador intérprete en el Libro de Alexandre y en el Libro de Apolonio". - Literatura y conocimiento medieval. Actas de las VIII Jornadas Medievales, eds. L. von der Walde, C. Company y A. González (México, 2003), pp. 199-208.

53-898. Pinet, Simone - "Babel historiada, traducida: un episodio del Libro de Alexandre". - Literatura y conocimiento medieval. Actas de las VIII Jornadas Medievales, eds. L. von der Walde, C. Company y A. González (México, 2003), pp. 371-389.

V. también núm. 931.

\section{Libro de Apolonio}

V. núms. 894, 897.

\section{Libro del Caballero Zifar}

53-899. Cacho Blecua, José Manuel "El género del Cifar (Sevilla, Cromberger, 1512)". — BICC, 54 (1999), 76-105.

53-900. Flores, R. M. - "Transfiriendo a dos iluminaciones la doctrina cristia- na implícita en un pasaje escrito del Libro del caballero Cifar". - RNo, 42 (2001), 3-15.

53-901. Gómez Redondo, Fernando "Los modelos caballerescos del $\mathrm{Zi}$ far". - BICC, 54 (1999), 106-154.

\section{Libro del conosçimiento...}

53-902. Libro del conoscimiento de todos los rregnos et tierras et señorios que son por el mundo, et de las señales et armas que han. Ed. facs. del manuscrito Z (Munich, Bayerische Staatsbibliotek, Cod. hisp. 150). Ed. de María de Jesús Lacarra, María Carmen Lacarra Ducay y Alberto Montaner. - Institución "Fernando el Católico", Zaragoza, 1999. 267 pp. II Incipit, 20/21 (2000-01), 210-216 (Bizarri).

\section{López de Ayala, Pero}

53-903. Ferro, Jorge N. - "Ayala y la aventura portuguesa de Juan I". Incipit, 22 (2002), 133-143.

\section{Lucena, Luis de}

53-904. Morros, Bienvenido - "Piccolomini y la Repetición de amores". - RFE, 83 (2003), 299-309.

\section{Mandevilla, Juan de}

53-905. Rodríguez Temperley, Mercedes - "Edición crítica del mansucrito escurialense M-III-7 (Libro de las maravillas del mundo, de Juan de Mandevilla). Problemas y respuestas". - Incipit, 22 (2002), 145-158. 53-906. Rodríguez Temperley, Mercedes - "Juan de Mandevilla en España: variaciones textuales y cambios culturales". - Literatura y conocimiento medieval. Actas de las VIII Jornadas Medievales, eds. L. von der Walde, C. Company y A. González (México, 2003), pp. 355-370 
Manrique, Jorge

53-907. Cortijo Ocaña, ANTONIO - "Notas a propósito del Convite burlesco de Jorge Manrique a su madrastra". RFE, 83 (2003), 133-144.

V. también núm. 949.

\section{Mena, Juan de}

53-908. Mauritzi, FrançoISE - "El Sol y Saturno en el Laberinto de fortuna". - $\mathrm{Li}$ teratura y conocimiento medieval. Actas de las VIII Jornadas Medievales, eds. L. von der Walde, C. Company y A. González (México, 2003), pp. 187-198.

\section{Núñez, Fernán}

53-909. Núnezz, Hernán - Refranes o proverbios en romance. Ed. crítica de $\mathrm{L}$. Combet, J. Sevilla Muñoz, G. Conde Tarrío y J. Guia i Marín. - Guillermo Blázquez Editor, Madrid, 2001. $452+$ 280 pp. II RLit, 64 (2002), 614-617 (Gómez Álvarez).

53-910. Madroñal, Abraham - "Los $R e$ franes o proverbios en romance (1555), de Hernán Núnez, Pinciano". RLit, 64 (2002), 5-39.

\section{Poema del Cid}

53-911. Coello Mesa, Antonia María "Ende en el Poema de mio Cid: caracterización sintáctica y semántica". $R F E, 83$ (2003), 249-260.

53-912. Galván, L. - El "Poema del Cid" en España, 1779-1936: recepción, mediación, historia de la filología (N. 51-956). II Ibero, 2003, núm. 11, 246-247 (Rodiek). - V. núm. 51-2522.

53-913. Historia latina de Rodrigo Díaz de Vivar. Ed., trad. y est. de José Manuel Ruiz Ascencio e Irene Ruiz Albi; est. prelim. de Gonzalo Martínez Díez. Ayuntamiento, Burgos, 1999. II Incipit, 22 (2002), 187-193 (Zaderenko).

53-914. Miranda, Francisco - "Regalos, jerarquía y rivalidad en el Poema de mio Cid". - RCFH, 27 (2003), 271-290.
53-915. Peukes, Gerhard - $O$ motivo de cavalo e do açor. Sua transformação no "Poema de mio Cid". - Centro Universitario Ibero-Americano, São Paulo, 2001. 92 pp. II ZRPh, 119 (2003), 192193 (Wild).

\section{Roís de Corella, Joan}

53-916. Martos, Josep Lluís - "La Historia destructionis Troiae como fuente de las prosas mitológicas de Joan Roís de Corella". - Literatura y conocimiento medieval. Actas de las VIII Jornadas Medievales, eds. L. von der Walde, C. Company y A. González (México, 2003), pp. 297-327.

\section{Rojas, Fermando de}

53-917. Botta, Patrizia — "Onomástica y crítica textual: peripecias de los nombres propios en la historia textual de La Celestina". - Criticón, 2003, núms. 87/88/89, 97-111.

53-918. Carrasco, Pilar (ed.) - El mundo como contienda. Estudios sobre " $\mathrm{La} \mathrm{Ce}$ lestina” - Universidad, Málaga, 2000. 242 pp. II Ibero, 2003, núm. 11, 239-240 (Maestro).

53-919. Costa Fontes, Manuel da - The art of subversion in inquisitorial Spain. Rojas and Delicado. - Purdue University Press, West Lafayette, Indiana, 2005. 346 pp. (Purdue Studies in Romance Literatures, 30 ).

53-920. Miaja de la Peña, María Teresa "Medianeras y presas: los personajes femeninos involucrados en el «cortejo modelo" en el Librade buen amory La Celestina". - Literatura y conocimiento medieval. Actas de las VIII Jornadas Medievales, eds. L. von der Walde, C. Company y A. González (México, 2003), pp. 169-186.

53-921. Mota, CARlos - "La Celestina, de la comedia humanística al pliego suelto. Sobre el Romance de Calisto y Melibea". - Criticón, 2003, núms. 87/88/89, 519-535.

V. también núm. 122 
Ruiz, Juan

53-922. Amasuno, Marcelino V. - "El saber médico tras el prólogo del Libro de buen amor. loco amor y amor hereos". - Juan Ruiz, Arcipreste de Hita, y el "Libro de buen amor", eds. F. Toro Ceballos y B. Morros (Alcalá la Real, 2004), pp. 247-270.

53-923. Bellido Morillas, José Marías "El libro como personaje literario en la obra del Arcipreste de Hita". Juan Ruiz, Arcipreste de Hita, y el "Libro de buen amor", eds. F. Toro Ceballos y B. Morros (Alcalá la Real, 2004), pp. 421-424.

53-924. Calleja Gujjarro, Tomás - "Las dos rutas segovianas del Libro de buen amor". - Juan Ruiz, Arcipreste de Hita, y el "Libro de buen amor", eds. F. Toro Ceballos y B. Morros (Alcalá la Real, 2004), pp. 317-326.

53-925. Carrizo Rueda, Sofí M. - "Un abordaje del Libro de buen amor desde las teorias hermenéuticas de Paul Ricoeur". - Juan Ruiz, Arcipreste de Hita, y el "Libro de buen amor", eds. F. Toro Ceballos y B. Morros (Alcalá la Real, 2004), pp. 303308.

53-926. Cuartero Sacho, María Pilar "La paremiología en el Libro de buen amor". - Juan Ruiz, Arcipreste de Hita, y el "Libro de buen amor", eds. F. Toro Ceballos y B. Morros (Alcalá la Real, 2004), pp. $215-234$.

53-927. Deyernond, Alan - "La difusión y recepción del Libro de buen amordesde Juan Ruiz hasta Tomás Antonio Sánchez: cronología provisional". Juan Ruiz, Arcipreste de Hita, y el "Libro de buen amor", eds. F. Toro Ceballos y B. Morros (Alcalá la Real, 2004), pp. 129-142.

53-928. Fallend, Ksenija - "Virgilio, Venus y Saturno en el ejemplo de «luxurian: una lectura alquímica del Libro de buen amor". - Juan Ruiz, Arcipreste de Hita, y el "Libro de buen amor", eds. F. Toro Ceballos y B. Morros (Alcalá la Real, 2004), pp. 425-436.

53-929. Fernández-Precio Cabezas, José MARÍA - "Iconografía e iconología del amor: de Eros y Cupido a Don Amor". - Juan Ruiz, Arcipreste de $\mathrm{Hi}$ - ta, y el "Libro de buen amor", eds. F. Toro Ceballos y B. Morros (Alcalá la Real, 2004), pp. 437-439.

53-930. García, Jorge - "La influencia del Libro de Aleixandre en el Libro de buen amor". - Juan Ruiz, Arcipreste de Hita, y el "Libro de buen amor", eds. F. Toro Ceballos y B. Morros (Alcalá la Real, 2004), pp. 183-198.

53-931. García Lizana, Avtonio - "La economía en el Libro de buen amor". - Juan Ruiz, Arcipreste de Hita, y el "Libro de buen amor", eds. F. Toro Ceballos y B. Morros (Alcalá la Real, 2004), pp. 395-408.

53-932. Garrido Arredondo, José - "El derecho mercantil en el Libro de buen. amor". - Juan Ruiz, Arcipreste de Hita, y el "Libro de buen amor", eds. F. Toro Ceballos y B. Morros (Alcalá la Real, 2004), pp. 409-419.

53-933. Gonzálvez Rliz, Ramón - "La persona de Juan Ruiz". - Juan Ruiz, Arcipreste de Hita, y el "Libro de buen amor", eds. F. Toro Ceballos y B. Morros (Alcalá la Real, 2004), pp. 37-67.

53-934. Hawley Colón, Carlos - "La cultura del Arcipreste: prácticas materiales". - Juan Ruiz, Arcipreste de Hita, y el "Libro de buen amor", eds. F. Toro Ceballos y B. Morros (Alcalá la Real, 2004), pp. 375-378.

53-935. HAYwoOD, Louise M. - "El cuerpo grotesco en el Libro de buen amor". - Juan Ruiz, Arcipreste de Hita, y el " $\mathrm{Li}$ bro de buen amor", eds. F. Toro Ceballos y B. Morros (Alcalá la Real, 2004), pp. 441-450.

53-936. Hutcheson, Gregory S. - "La heteronormatividad en disputa". Juan Ruiz, Arcipreste de Hita, y el "Libro de buen amor", eds. F. Toro Ceballos y B. Morros (Alcalá la Real, 2004), pp. 327-330.

53-937. Jacinto García, Eduardo José "El Libro de buen amor como obra abierta: una aproximación desde las teorías de Umberto Eco". - Juan Ruiz, Arcipreste de Hita, y el "Libro de buen amor", eds. F. Toro Ceballos y B. Morros (Alcalá la Real, 2004), pp. 379-385.

53-938. Joset, Jacques - "El pensamiento de Juan Ruiz". - Juan Ruiz, Arcipreste de Hita, y el "Libro de buen amor", 
eds. F. Toro Ceballos y B. Morros (Alcalá la Real, 2004), pp. 105-128.

53-939. Jlan Lovera, Carmen - "Datos biográficos de Juan Ruiz de Cisneros y acontecimientos históricos reflejados en el Libro de buen amor". - Juan Ruiz, Arcipreste de Hita, y el "Libro de buen amor", eds. F. Toro Ceballos y B. Morros (Alcalá la Real, 2004), pp. 309-316.

53-940. Juan Lovera, Carmen y Francisco Toro Ceballos - "Copia manuscrita del Libro de buen amor en Alcalá la Real". - Juan Ruiz, Arcipreste de Hita, y el "Libro de buen amor", eds. F. Toro Ceballos y B. Morros (Alcalá la Real, 2004), pp. 451-455.

53-941. Jurado, José - "Aguas byuas, $L B A$ 302a". - RCEH, 27 (2003), 347-354.

53-942. Linage Conde, ANtonio - "El mundo del Arcipreste de Hita". Juan Ruiz, Arcipreste de Hita, y el "Libro de buen amor", eds. F. Toro Ceballos y B. Morros (Alcalá la Real, 2004), pp. 199-214.

53-943. Márqlez Villanleva, Francisco - "Juan Ruiz y el celibato eclesiástico". - Juan Ruiz, Arcipreste de Hita, y el "Libro de buen amor", eds. F. Toro Ceballos y B. Morros (Alcalá la Real, 2004), pp. 17-33.

53-944. Molina González, Manuel - “ $L i$ bro de buen amor en la educación secundaria española: otro clásico en el olvido". - Juan Ruiz, Arcipreste de Hita, y el "Libro de buen amor", eds. F. Toro Ceballos y B. Morros (Alcalá la Real, 2004), pp. 387-394.

53-945. Morros, Bienvenido - "La fuentes del Libro de buen amor". - Juan Ruiz, Arcipreste de Hita, y el "Libro de buen amor", eds. F. Toro Ceballos y B. Morros (Alcalá la Real, 2004), pp. 69-104.

53-946. Nieto Pérez, M. de los Reyes - "El libro como creador de realidad en el Libro de buen amor". - Juan Ruiz, Arcipreste de Hita, y el "Libro de buen amor", eds. F. Toro Ceballos y B. Morros (Alcalá la Real, 2004), pp. 363-368.

53-947. Paredes, JuAN - " "Que los cuerpos alegre e a las almas preste». Teoría y praxis en el Libro de buen amor". - Juan Ruiz, Arcipreste de Hita, y el "Iibro de buen amor", eds. F. Toro Ceba- llos y B. Morros (Alcalá la Real, 2004), pp. 273-280.

53-948. PeÑa González, José — "Juan Ruiz Arcipreste de Hita. Lírica y pensamiento". - Juan Ruiz, Arcipreste de Hita, y el "Libro de buen amor", eds. F. Toro Ceballos y B. Morros (Alacalá la Real, 2004), pp. 331-334.

53-949. Pérez Fernández, Desirée — "El Libro de buen amor, La danza de la muerte y las Coplas de Manrique en un montaje actual: Coplas por la muerte". - EHF, 26 (2004), 219-233.

53-950. Pérez López, José Luis - "Investigaciones sobre el Libro de buen amor en el Archivo y Biblioteca de la Catedral de Toledo". - Juan Ruiz, Arci preste de Hita, y el "Libro de buen amor", eds. F. Toro Ceballos y B. Morros (Alcalá la Real, 2004), pp. 281-302.

53-951. Pérez LóPez, José Luis - "La fecha del Libro de buen amor". - Incipit, 22 (2002), 95-132.

53-952. REY, PEPE - "Puntos y notas al músico Juan Ruiz". - Juan Ruiz, Arcipreste de Hita, y el "Libro de buen amor", eds. F. Toro Ceballos y B. Morros (Alcalá la Real, 2004), pp. 235-246.

53-953. Rico, Francisco - "La función del Arcipreste". - Juan Ruiz, Arcipreste de Hita, y el "Libro de buen amor", eds. F. Toro Ceballos y B. Morros (Alcalá la Real, 2004), pp. 13-14.

53-954. Rúbiales Roldán, ANtonio "Anthony N. Zahareas: The art of Juan Ruiz, Archpriest of Hita". - Juan Ruiz, Arcipreste de Hita, y el "Libro de buen amor", eds. F. Toro Ceballos y B. Morros (Alcalá la Real, 2004), pp. 335-340.

53-955. Sáxchez Vázquez, M. Esperanza - "Fórmulas épicas en el Libro de buen amor". - Juan Ruiz, Arcipreste de Hita, y el "Libro de buen amor", eds. F. Toro Ceballos y B. Morros (Alcalá la Real, 2004), pp. 341-348.

53-956. Stefano, GiusePPe DI - "El público de Juan Ruiz y el destinatario del Arcipreste". - Literatura y conocimiento medieval. Actas de las VIII Jornadas Medievales, eds. L. von der Walde, C. Company y A. González (México, 2003), pp. 17-31.

53-957. Tabarfs Pascencia, Excarnación — "La fábula del lobo y la raposa. Un 
ejemplo de la precisión terminológica y del saber jurídico del Arcipreste". - RFLL, 22 (2004), 299-311.

53-958. Várvaro, Alberto - "El texto del Libro de buen amor". - Juan Ruiz, Arcipreste de Hita, y el "Libro de buen amor", eds. F. Toro Ceballos y B. Morros (Alcalá la Real, 2004), pp. 143-180.

53-959. VentlRA, JoAQUim - "La tradición del pacto diabólico en el Libro de buen amor: el «Enxienplo del ladrón que fizo carta al diablo de su ánima”". - Juan Ruiz, Arcipreste de Hita, y el "Libro de buen amor", eds. F. Toro Ceballos y B. Morros (Alcalá la Real, 2004), pp. 369-373.

V. también núms. 580, 606, 920.

\section{Santa Maria, Pablo de}

53-960. Conde, J. C. - La creación de un discurso historiográfico en el Cuatrocientos castellano: Las "Siete edades del mundo" de Pablo de Santa Maria. (Estudios y edición crítica) (N. 50-951). II ZRPh, 119 (2003), 780-782 (Lebsanft). - V. núm. 51-2585.

\section{Santillana, Marqués de}

53-961. Gimeno Casalduero, Joaquín "El proceso creativo en la canción del Marqués de Santillana «Dios vos fizo virtuosa»". - Studies in honor of Denah Lida, eds. M. G. Berg \& Lanin A. Gyurko (Potomac, Maryland, 2005), pp. 44-55.

53-962. Leuker, Tobias - "Propuestas textuales para algunos sonetos del Marqués de Santillana”. - VR, 62 (2003), 194-203.

Sendebar. Libro de los engaños e los assayamientos de las mugeres

53-963. Vilchis Frausto, José Carlos "Una omisión en Sendebar". - Literatura y conocimiento medieval. Actas de las VIII Jornadas Medievales, eds. L. von der Walde, C. Company y A. González (México, 2003), pp. 209-216
Tafur, Pero

53-964. Rodilla, María José - "Espacios sagrados y espacios míticos. La retórica del viaje en las Andancas de Pero Tafur". - Literatura y conocimiento medieval. Actas de las VIII Jornadas Medievales, eds. L. von der Walde, C. Company y A. González (México, 2003), pp. 345-353.

\section{Tristán de Leonís}

53-965. Ros Domingo, E. A. - Arthurische Literatur der Romania. Die iberorromanischen Fassungen des Tristanromans und ihre Beziehungen zu den französischen und italienischen Versionen (N. 50530). II ZRPh, 119 (2003), 530-534 (Wild).

Villena, Enrique de

53-966. Marcos Celestino, Mónica - "El Marqués de Villena y La cueva de Salamanca. Entre literatura, historia y leyenda". - EHF, 26 (2004), 155-185.

Ximénez de Rada, Rodrigo

53-967. Ward, Aengus - "Posturas ideológicas en la Versión leonesa del Toledano". - Literatura y conocimiento medieval. Actas de las VIII Jornadas Medievales, eds. L. von der Walde, $\mathrm{C}$. Company y A. González (México, 2003), pp. 441-455.

\section{SIGLOS DE ORO}

Aguilar, Gaspar Honorat de

V. núm. 1189.

\section{Alemán, Mateo}

V. núm. 1039. 


\section{Arias Montano, Benito}

53-968. Macías, BaLdomero - "La correspondencia de Arias Montano con Abraham Ortelio: nuevos testimonios de una amistad sin fronteras". $C D, 217$ (2004), 551-572.

\section{Bances Candamo, Francisco Antonio de}

53-969. Pérez Magallón, Jesús - "Guerra y Bances Candamo en la canonización de Calderón". - RCEH, 27 (2003), 509-531.

\section{Calancha, fray Antonio de la}

53-970. Mora, Carmen de - "Vidas, milagros y casos en la Corónica moralizada de fray Antonio de la Calancha". - I, 2003, núm. 58, 62-82.

\section{Calderón de la Barca, Pedro}

53-971. Calderón de la Barca, P. - El santo rey don Fernando (Primera parte), eds. I. Arellano, J. M. Escudero y M. C. Pinillos (N. 51-2599). II Incipit, 22 (2003), 245-245 (Altamiranda).

53-972. Calderón de la Barca, P. - La humildad coronada, ed. I. Arellano (N. 52-2426). II RLit, 65 (2003), 627-628 (Pérez Ibáñez).

53-973. Arellano, I. - Calderón y su escuela dramática (N. 50-977). II RCEH, 27 (2003), 360-362 (Lauer). - V. núm. 51-2602.

53-974. Arellano, I. - Diccionatio de los autos sacramentales de Calderón (N. 512603). II Ibero, 2003, núm. 12, 224-225 (Pardellas Velay).

53-975. Arellano, I. (dir.) - Comedias burlescas del Siglo de Oro. T. 2. - Iberoamericana-Universidad de Navarra, Madrid-Pamplona, 2001. II RLit, 64 (2002), 274-276 (García Cabrera). - V. núm. 49-2185.

53-976. Areillano, Ignacio - "Toledo, plaza de armas de la fe, y los autos toledanos de Calderón". - Criticón, 2003, núms. 87/88/89, 59-75.[Tam- bién en $S L L, 5$ (2003), núm. 2, 7393].

53-977. Arellano, Ignacio y Germán Vega García-Luengos (eds.) - Calderón: innovación y legado. Actas selectas del IX Congreso de la Asociación Internacional de Teatro Español y Novohispano de los Siglos de Oro, en colaboración con el Grupo de Investigación Siglo de Oro de la Universidad de Navarra (Pamplona, 27 al 29 de marzo de 2000). - P. Lang, New York, 2001. II SLL, 5 (2003), núm. 2, 107-113 (Higashi).

53-978. Arnscheidt, Gero y Rosama ParDELlas Velay - "Calderón en la escena de habla alemana (1990-2001). Análisis estadístico". - Teatro calderoniano sobre el tablado. Calderón y su puesta en escena a través de los siglos. XIII Coloquio Anglogermano sobre Calderón, Florencia, 10-14 de julio de 2002, ed. M. Tietz (Stuttgart, 2003), pp. 493-499.

53-979. Briesemeister, Dietrich — "Das Einsiedler Welttheater, último retoque alemán del Gran teatro del mundo calderoniano". - Teatro calderoniano sobre el tablado. Calderón y su puesta en escena a través de los siglos. XIII Coloquio Anglogermano sobre Calderón, Florencia, 10-14 de julio de 2002, ed. M. Tietz (Stuttgart, 2003), pp. 9-25.

53-980. Blezo, Catalina - "La función del ángel en la puesta en escena del auto sacramental calderoniano". Teatro calderoniano sobre el tablado. Calderón y su puesta en escena a través de los siglos. XIII Coloquio Anglogermano sobre Calderón, Florencia, 10-14 de julio de 2002, ed. M. Tietz (Stuttgart, 2003), pp. 27-41.

53-981. Campbel. Y, Ysla - "Aspectos ideológicos en Guárdate del agua mansa". - Teatro calderoniano sobre el tablado. Calderón y su puesta en escena a través de los siglos. XIII Coloquio Anglogermano sobre Calderón, Florencia, 10-14 de julio de 2002, ed. M. Tietz (Stuttgart, 2003), pp. 43-48.

53-982. CaNavaggio, Jean - "Una escenografía de El mágico prodigioso". Teatro calderoniano sobre el tablado. Calderón y su puesta en escena a través de los siglos. XIII Coloquio Anglogermano sobre 
Calderón, Florencia, 10-14 de julio de 2002, ed. M. Tietz (Stuttgart, 2003), pp. 49-62.

53-983. Cancelliere, Enrica - "Dos tipos de locura: la rebelión de Segismundo y la obediencia de don Fernando". - Criticón, 2003, núms. 87/ 88/89, 129-141.

53-984. Carrión, Maria M. - "The burden of evidence: Performances of marriage, violence, and the law in $E l$ médico de su honra". - RCEH, 27 (2003), 447-468.

53-985. Chaves Montoya, María Teresa - " "Las rimas, el color y el canto engañarán las almas con deleitoso encanto". Baccio del Bianco, Giulio Rospigliosi y las «fortunas» del parlar cantando en el teatro calderoniano". - Criticón, 2003, núms. 87/88/89, 161-174.

53-986. Díez Borqle, José María - "Encuentros escénicos de los dioses en Calderón de la Barca". - Teatro calderoniano sobre el tablado. Calderón y su puesta en escena a través de los siglos. XIII Coloquio Anglogermano sobre Calderón, Florencia, 10-14 de julio de 2002, ed. M. Tietz (Stuttgart, 2003), pp. 63-83.

53-987. Egido, A. (ed.) - Lecciones calderonianas $(\mathrm{N} .52-827)$. II $I, 2003$, núm. 57, 163-166 (Xuan).

53-988. Esseni, Chiara — "Albert Camus adattore de La devoción de la Cruz". Teatro calderoniano sobre el tablado. Calderón y su puesta en escena a través de los siglos. XIII Coloquio Anglogermano sobre Calderón, Florencia, 10-14 de julio de 2002, ed. M. Tietz (Stuttgart, 2003), pp. 85-96.

53-989. Fervández Mosqlera, Santiago - "La tempestad en Calderón: del texto a las tablas". - Teatro calderoniano sobre el tablado. Calderón y su puesta en escena a través de los siglos. XIII Coloquio Anglogermano sobre Calderón, Florencia, 10-14 de julio de 2002, ed. M. Tietz (Stuttgart, 2003), pp. 97-128.

53-990. Ferrer Valis, TeresA - "Sobre la fecha de composición de los autos de Calderón El veneno y la triaca y La hi. dalga del valle". — Criticón, 2003, núms. 87/88/89, 287-298.
53-991. Fischer, Susan L. — "La apropiación de Calderón en escena: El médico de su honra y El alcalde de Zalamea". Teatro calderoniano sobre el tablado. Calderón y su puesta en escena a través de los siglos. XIII Coloquio Anglogermano sobre Calderôn, Florencia, 10-14 de julio de 2002, ed. M. Tietz. (Stuttgart, 2003), pp. 129-144.

53-992. Froldi, Runaldo - "La gran comedia de La hija del aire". - Teatro calderoniano sobre el tablado. Calderón y su puesta en escena a través de los siglos. XIII Coloquio Anglogermano sobre Calderón, Florencia, 10-14 de julio de 2002, ed. M. Tietz (Stuttgart, 2003), pp. 145-161.

53-993. Garcia Gómez, Ángel Maria "Contextualización de las primeras puestas en escena de La vida es sueño (1925-1929) en Inglaterra dentro del marco de la crítica anglo-irlandesa del siglo xIx". - Teatro calderoniano sobre el tablado. Calderón y su puesta en escena a través de los siglos. XIII Coloquio Anglogermano sobre Calderón, Florencia, 10-14 de julio de 2002, ed. M. Tietz (Stuttgart, 2003), pp. 163-193.

53-994. González, A. (ed.) - Calderón 1600-2000. Jornadas de investigación calderoniana (N. 50-2215). II SLL, 5 (2003), núm. 2, 107-113 (Higashi).

53-995. Hernández Araico, Susana "Calderón seduce a Los Angeles: sus pasiones en la Fundación Bilingüe de las Artes". - Teatro calderoniano sobre el tablado. Calderón y su puesta en escena a través de los siglos. XIII Coloquio Anglogermano sobre Calderón, Florencia, 10-14 de julio de 2002, ed. M. Tietz (Stuttgart, 2003), pp. 195-206.

53-996. Iglesias Fiejoo, Luis y Maria CaAMAÑo Rojo - "Calderón, del teatro a la escena. Con la noticia de una nueva Segunda Parte de Vera y Tassis". Teatro calderoniano sobre el tablado. Calderón y su puesta en escena a través de los siglos. XIII Coloquio Anglogermano sobre Calderón, Florencia, 10-14 de julio de 2002, ed. M. Tietz (Stuttgart, 2003), pp. 207-223.

53-997. Johnstox, Robert M. - "El movimiento escénico y las «relaciones proxémicas" en A secreto agravio, secre- 
ta venganza y El pintor de su deshonra de Calderón". - Teatro calderoniano sobre el tablado. Calderón y su puesta en escena a través de los siglos. XIII Coloquio Anglogermano sobre Calderón, Florencia, $10-14$ de julio de 2002, ed. M. Tietz (Stuttgart, 2003), pp. 235-249.

53-998. LALER, ROBERT - "El planteamiento escénico de El tesoro escondido, auto sacramental historial calderoniano". - Teatro calderoniano sobre el tablado. Calderón y su puesta en escena a través de los siglos. XIII Coloquio Anglogermano sobre Calderón, Florencia, 10-14 de julio de 2002, ed. M. Tietz (Stuttgart, 2003), pp. 251-260.

53-999. LóPEZ, NELSON - "Multimedia y estilos de actuación en Mañana será otro día en la producción del Teatro Rodante". - Teatro calderoniano sobre el tablado. Calderón y su puesta en escena a través de los siglos. XIII Coloquio Anglogermano sobre Calderón, Florencia, 10-14 de julio de 2002, ed. M. Tietz (Stuttgart, 2003), pp. 275-283.

53-1000. Madroñal, Abraham - "Tres nuevos manuscritos y una edición desconocida de los entremeses de Calderón”. - Criticón, 2003, núms. $87 / 88 / 89,441-457$.

53-1001. Maestro, Jesús G. — "Los límites de una interpretación trágica y contemporánea del teatro calderoniano: El príncipe constante". - Teatro calderoniano sobre el tablado. Calderón y su puesia en escena a través de los siglos. XIII Coloquio Anglogermano sobre Calderón, Florencia, 10-14 de julio de 2002, ed. M. Tietz (Stuttgart, 2003), pp. 285-327.

53-1002. MéNdez, SigmuNd - El mito fáustico en el drama de Calderón. - Reichenberger, Kassel, 2000. 395 pp. II Ibero, 2003, núm. 10, 202-204 (Sánchez Jiménez).

53-1003. MLjICA, Bárbara - "Calderón para ateos: la producción de Sueño de José Carrasquillo". - Teatro calderoniano sobre el tablado. Calderón y su puesta en escena a través de los siglos. XIII Coloquio Anglogermano sobre Calde rón, Florencia, 10-14 de julio de 2002, ed. M. Tietz (Stuttgart, 2003), pp. 329-341.
53-1004. Neumeister, S. - Mito clásico y ostentación. Los dramas mitológicos de Calderón (N. 49-2339). II RLit, 65 (2003), 289-292 (Rull). - V. núm. $52-2523$.

53-1005. Neumeister, Sebastian - "Visualización encantadora: las comedias fantásticas de Calderón”. - Teatro calderoniano sobre el tablado. Calderón y su puesta en escena a través de los siglos. XIII Coloquio Anglogermano sobre Calderón, Florencia, 10-14 de julio de 2002, ed. M. Tietz (Stuttgart, 2003), pp. 343-357.

53-1006. Nider, Vale`Tina - "El motivo del «reparto de los reinos» entre politica y literatura". - Criticón, 2003, núms. 87/88/89, 553-565.

53-1007. Novo, YOIANDA - "A vueltas con los manuscritos calderonianos: notas para la edición crítica de Saber del mal y del bien". - Criticón, 2003, núms. 87/88/89, 577-587.

53-1008. Novo, Yolanda - "Rasgos escenográficos y reconstrucción escénica de La gran Cenobia (1636), una tragedia histórica de la Parte primera". Teatro calderoniano sobre el tablado. Calderón y su puesta en escena a través de los siglos. XIII Coloquio Anglogermano sobre Calderón, Florencia, 10-14 de julio de 2002, ed. M. Tietz (Stuttgart, 2003), pp. 359-390.

53-1009. Rodiek, ChristopH - "La adaptación enzensbergeriana (1992) de La hija del aire". - Teatro calderoniano sobre el tablado. Calderón y su puesta en escena a través de los siglos. XIII Coloquio Anglogermano sobre Calderón, Florencia, 10-14 de julio de 2002, ed. M. Tietz (Stuttgart, 2003), pp. 391-403.

53-1010. Rodrigles Vianna Peres, Lygia - "La vida es sueño en los tablados de Brasil". - Teatro calderoniano sobre el tablado. Calderón y su puesta en escena a través de los siglos. XIII Coloquio Anglogermano sobre Calderón, Florencia, 10-14 de julio de 2002, ed. M. Tietz (Stuttgart, 2003), pp. 405-412.

53-1011. Rose, Constance H. - "Otra mirada a Hércules: Fieras afemina amor". - Teatro calderoniano sobre el tablado. Calderón y su puesta en escena a través de los siglos. XIII Coloquio Anglo- 
germano sobre Calderón, Florencia, 10-14 de julio de 2002, ed. M. Tietz (Stuttgart, 2003), pp. 413-422.

53-1012. Rliz Ramón, Francisco - "Calderón dramaturgo: ¿clásico y/o contemporáneo?". - Teatro calderoniano sobre el tablado. Calderón y su puesta en escena a través de los siglos. XIII Coloquio Anglogermano sobre Calderón, Florencia, 10-14 de julio de 2002, ed. M. Tietz (Stuttgart, 2003), pp. 423-431.

53-1013. Ruiz Ramón, Francisco - Calderón nuestro contemporáneo. El escenario imaginario. Ensayo sinóptico. - Castalia, Madrid, 2000. 236 pp. II Ibero, 2003, núm. 10, 200-202 (Geisler).

53-1014. RulL, ENRIQLE - "El camino de la mina, vehículo de emociones en Calderón". - RLit, 64 (2002), 385411.

53-1015. San Miguel, Ángel - "El médico de su honra y El gran teatro del mundo en la "Antigua Corte» de Bamberg (1987)". - Teatro calderoniano sobre el tablado. Calderón y su puesta en escena a través de los siglos. XIII Coloquio Anglogermano sobre Calderón, Florencia, 10-14 de julio de 2002, ed. M. Tietz (Stuttgart, 2003), pp. 433-442.

53-1016. Schizzano Mandel, Adrienne -

"La vida es sueño: nuevas interpretaciones escénicas". - Teatro calderoniano sobre el tablado. Calderón y su puesta en escena a través de los siglos. XIII Coloquio Anglogermano sobre Calderón, Florencia, 10-14 de julio de 2002, ed. M. Tietz (Stuttgart, 2003), pp. 443-454.

53-1017. Scholz-Hänsel, Michael "Imágenes escénicas al servicio de la propaganda de los Austrias. Pintores y poetas del Siglo de Oro en diálogo". - Teatro calderoniano sobre el tablado. Calderón y su puesta en escena a través de los siglos. XIII Coloquio Anglogermano sobre Calderón, Florencia, 10-14 de julio de 2002, ed. M. Tietz (Stuttgart, 2003), pp. 455-465.

53-1018. SePúlveda, Jesús - "Haz y envés de convenciones en El escondido y la tapada de Pedro Calderón de la Barca". - Criticón, 2003, núms. 87/88/89, 815-826.

53-1019. Suárez, JuAn Lưs - El escenario de la imaginación: Calderón en su teatro.
- Universidad de Navarra, Pamplona, 2002. 244 pp. II RCEH, 27 (2003), 604-606 (Friedman).

53-1020. SUÁREz, JUAN Luis - "El reconocimiento de la complejidad. Información dispersa y conocimiento incompleto en La vida es sueño". Edad de Oro, 23 (2004), 355-368.

53-1021. Suárez, JuAn LuIs - "La ocasión y la representación del tiempo en La vida es sueño". - Teatro calderoniano sobre el tablado. Calderón y su puesta en escena a través de los siglos. XIII Coloquio Anglogermano sobre Calderón, Florencia, 10-14 de julio de 2002, ed. M. Tietz (Stuttgart, 2003), pp. $467-478$.

53-1022. Suárez Miramón, Ana - "Los caminos celestes en el teatro de Calderón”. - RLit, 65 (2003), 213-224.

53-1023. Tietz, Manfred (ed.) - Teatro calderoniano sobre el tablado. Calderón y su puesta en escena a través de los siglos. XIII Coloquio Anglogermano sobre Calderón, Florencia, 10-14 de julio de 2002. Franz Steiner Verlag, Stuttgart, 2003. 529 pp. + CD-ROM (Archivum Calderonianum, 10).

53-1024. Vega García Luevgos, Germán - "Ecos de Rosaura (para leer mejor el inicio de La vida es sueño e incrementar el repertorio calderoniano)". - Criticón, 2003, núms. 87/88/89, 887-898.

53-1025. Vega García-Luengos, G., W. Crutcshank y J. M. Rlano de la Haza (eds.) - La segunda versión de "La vida es sueño", de Calderón (N. 50-1002). II RCEH, 27 (2003), 380-382 (Greer).

53-1026. Vuelta García, Salomé - "En torno a una traducción florentina de El secreto a voces de Calderón: Il segreto in publico de Giacinto Andrea Cicognini”. - Criticón, 2003, núms. 87/88/89, 915-924.

53-1027. Wright, Elizabeth R., Lolise M. Burkhart y Barry D. Sell - "Inspiración italiana y contexto americano: $E l$ gran teatro del mundo traducido por don Bartolomé de Alva Ixtlixóchitl". - Criticón, 2003, núms. 87/88/89, 925-934.

53-1028. XuAN, Jing - "Calderón y el cine. La vida es sueño y Abre los ojos de 
Alejandro Amenábar". - Teatro calderoniano sobre el tablado. Calderón y su puesta en escena a través de los siglos. XIII Coloquio Anglogermano sobre Calderón, Florencia, 10-14 de julio de 2002, ed. M. Tietz (Stuttgart, 2003), pp. 479-491.

V. también núms. 608, 969, 1210.

\section{Caro, Rodrigo}

53-1029. Pascual Barea, Joaqlín (ed.) - Rodrigo Caro. Poesía castellana y latina e inscripciones originales. - Diputación, Sevilla, 2000.348 pp. II RLit, 65 (2003), 282-285 (Alburquerque García).

\section{Castellanos, Juan de}

53-1030. Bolaños, ÁlVaro Félix - "Hispanismo y Colombia colonial: los lectores de la obra épica de Juan Castellanos". - I, 2003, núm. 58, 197-209.

\section{Castillejo, Cristóbal de}

53-1031. Reyes Cano, Rogelio - Estudios sobre Cristóbal de Castillejo. (Tradición y modernidad en la encrucijada poética del siglo XVI). - Universidad, Salamanca, 2000. 159 pp. II RLit, 64 (2002), 264268 (Bonilla Cerezo); Ibero, 2003, núm. 9, 225-227 (Sánchez Jiménez).

\section{Castro y Bellvís, Guillén de}

丂33-1032. Moreno, Charo - " "¿Qué haré entre tantas confusiones?»: sobre los padres dubitativos en el teatro de Guillén de Castro". - Criticón, 2003, núms. 87/88/89, 507-517.

53-1033. Stárez, Juan Luts - "La historización de un mito: el tiempo como problema y como solución en Las mocedades del Cid". - RCEH, 26 (2002), 493-509.

V. también núm. 1006.

\section{Cervantes de Salazar, Francisco}

53-1034. Madrigal, José LuIS - "Cervantes de Salazar y el Lazarillo: un estudio de atribución". - Ins, 2003, núm. 682, 9-13.

V. también núm. 1128.

\section{Cervantes Saavedra, Miguel de}

53-1035. Artigas, María del Carmen "Un breve comentario sobre el converso en El licenciado Vidriera". $R N o, 43$ (2002), 37-41.

53-1036. Bologna, Corrado - " "La mano en la mejilla»". - Criticón, 2003, núms. 87/88/89, 79-96.

53-1037. Cano Aguilar, Rafael - "La cohesión del discurso en la lengua de Cervantes". - Edad de Oro, 23 (2004), 135-159.

53-1038. CaSA, Frank P. - "Runaways in Cervantes". - Studies in honor of D $e^{-}$ nah Lida, eds. M. G. Berg \& Lanin A. Gyurko (Potomac, Maryland, 2005), pp. 113-122.

53-1039. Close, Anthony - "Cervantes y el pecado original, con un vistazo a Alemán”. - Ins, 2003, núm. 674, 31-33.

53-1040. Díaz Mas, Paloma - "Cómo enseñar a hablar a un elefante: un cuento de La gran sultana". - Criticón, 2003, núms. 87/88/89, 265-276.

53-1041. Fox, Dian - " ¿A mí León?" Don Quijote, Don Domingo de don Blas and mainless". - Studies in honor of Denah Lida, eds. M. G. Berg \& Lanin A. Gyurko (Potomac, Maryland, 2005), pp. 123-131.

53-1042. Friedman, Edward H. - "Past perfect: The battle against time in Don Quijote". - Studies in honor of Denah Lida, eds. M. G. Berg \& Lanin A. Gyurko (Potomac, Maryland, 2005), pp. 132-143.

53-1043. Garcés, María Antonia - "Los avatares de un nombre: Saavedra y Cervantes". - RLit, 65 (2003), 351-374.

53-1044. Grilli, GivsePpe - Literatura caballeresca y re-escrituras cervantinas. Centro de Estudios Cervantinos, Alcalá de Henares, 2004. 273 pp. (Biblioteca de Estudios Cervantinos, 14). 
53-1045. GutiérRez, ValeNTINA - "Don Quijote y la búsqueda de un sueño". - SLL, 5 (2003), núm. 1, 31-51.

53-1046. Laparra López, EMIlo - "El hispanismo en la Biblioteca Virtual Miguel de Cervantes". - FGL, 2003, núms. 33/34, 265-268.

53-1047. LORENZO, JAVIER - "Garcilasian echoes: myth and intertextuality in Cervantes' Numancia". - RNo, 42 (2002), 171-176.

53-1048. Martín Morán, José Mandel "Variedad en la unidad: estrategias de cohesión textual en el Quijote". - Criticón, 2003, núms. 87/88/89, 469-478.

53-1049. Miñava, R. - La verosimilitud en el Siglo de Oro: Cervantes y la novela corta (N. 50-2259). II RLit, 64 (2002), 630-634 (Ballesteros); NRFH, 52 (2004), 197-201 (López Martínez).

53-1050. Muñoz Sáxchez, Juan Ramón "Un ejemplo de interpolación cervantina: el episodio de Timbrio y Silerio de La Galatea". - AEF, 26 (2003), 279-297.

53-1051. NeUSChÃFER, H.-J. — La ética del "Quijote". Función de las novelas intercaladas (N. 47-2051). II RF, 115 (2003), 137-138 (Endress); Ibero, 2003, núm. 9, 229-230 (Maestro). - V. núm. 522616.

53-1052. Porqueras Mayo, A. - Estudios sobre Cervantes y la Edad de Oro (N. 52 870). II NRFH, 52 (2004), 202-203 (Sol Mora).

53-1053. Presberg, C. D. - Adventures in paradox. Don Quixote and the Western tradition (N. 51-1056). Il Ibero, 2003, núm. 11, 240-243 (Sánchez-Jiménez).

53-1054. Ramos, Óscar Gerardo - "Don Quijote de la Mancha, epopeya". BICC, 53 (1998), 324-334.

53-1055. Ruta, M. C. - "Elementos teatrales y elementos narrativos en los textos de cautiverio de Cervantes". - Criticón, 2003, núms. 87/88/89, 765-774.

53-1056. SOOK KIM, YUN - "Conflictos del deseo amoroso en las novelas de «Curioso impertinente» y de «Cardenio y Luscinda", incluidas en Don Quijote de la Mancha". - BICC, 53 (1998), 594-605.
53-1057. Trujlllo, José Ramón - "La traducción en Cervantes: lengua literaria y conciencia de autoría". - Edad de Oro, 23 (2004), 161-197.

53-1058. Vivar, Francisco - "La Numancia" de Cervantes y la memoria de un mito. - Biblioteca Nueva, Madrid, 2004. 174 pp.

53-1059. WORDEN, William - "Sancho Panza and the power of the spoken word in Don Quixote". - RNo, 44 (2003), 41-50.

V. también núms. 809, 874, 1119, 1120 , $1165,1638$.

\section{Claramonte, Andrés de}

V. núm. 1172.

\section{Colón, Cristóbal}

53-1060. Jármez, Rita - "Guatro cartas de Colón: qué dice, por qué lo dice y para qué lo dice". - $A L M, 40$ (2002), 159-204.

\section{Cortés, Hernán}

53-1061. Dolle, Vereina - " "Con bergantines y chalupas puestas de diez mil hombres en las corvas cuestas". Verdad histórica y ficción en el episodio de los bergantines cortesianos". - I, 2003, núm. 58, 146-170.

\section{Covarrubias [H]orozco, Sebastián de}

53-1062. Gordón Peral, María Dolores - "Sebastián de Covarrubias ante la diversidad sociolingüstica y estilística del español". - ZRPh, 119 (2003), 96-106.

Cruz, San Juan de la

53-1063. Cruz, JuAn de la - Cántico espiritual y Poesía completa. Ed. de Paola Elia y María Jesús Mancho; est. prelim. de Domingo Ynduráin. - Críti- 
ca, Barcelona, 2002. II AION-R, 45 (2003), 602-604 (Gorla).

53-1064. Andrés Gil, Carlos M. - La experiencia poética y la experiencia mística en la poesia de San Juan de la Cruz. Scripta Humanistica, Potomac, Maryland, 2004. 149 pp.

\section{Cruz, Sor Juana Inés de la}

53-1065. Alcázar, Jorge - La tradición emblemática en sor Juana Inés de la Cruz. - UNAM, México, 2002. II LMM, 14 (2003); 294-300 (Olivares Zorrilla).

53-1066. Corry, Jenvifer M. - "Inversión del castigo en el Primero sueño de sor Juana”. - RNo, 43 (2003), 219-228.

53-1067. Fiorelino, Barbara - "Primero Sueño y sus traducciones en verso al italiano". - Criticón, 2003, núms. 87/88/89, 299-310.

53-1068. Herrera Zapié, Tarcisio - "Del Primero Sueño al «Segundo Sueño». De Aristóteles a Teilhard de Chardin". LMM, 14 (2003), 179-196.

53-1069. SÁnchez VÁzQlez, Adolfo - "El "Sueño» metódico de sor Juana". LMM, 13 (2002), 49-63.

53-1070. SARabia, Rosa - "Sor Juana o las trampas de la restitución". RCEH, 27 (2002), 119-138.

53-1071. SCHMidHu'ber de LA MORA, GLII.LERMO - Sor Juana, dramaturga. Benemérita Universidad Autónoma de Puebla, Puebla, 1996. 217 pp. II SignosU, 2003, núm. 39, 251-253 (Barnaky de Proasi).

53-1072. Soriano Vallès, Alejandro "Un género supremo de providencia: sor Juana Inés de la Cruz y la tesis de los beneficios negativos en la Carta atenagórica". - LMM, 14 (2003), 23-62.

V. también núm. 1122.

\section{Delicado, Francisco}

53-1073. Folrquett-Reed, Linette Protofeminismo, erotismo y comida en " $L a$ lozana andaluza”. - Scripta Humanistica, Potomac, Maryland, 2004. 197 pp.

V. también núm. 919.

\section{Diamante, Juan Bautista}

V. núm. 1119.

Dominguez Camargo, Hernando

53-1074. Ramírez Sierra, Hugo Hernán - "Antonio Bastidas, crítico de la obra de don Hernando Domínguez Camargo en el siglo xvil". - BICC, 53 (1998), 527-552.

\section{Encina, Juan del}

V. núm. 122.

Fernández, Lucas

53-1075. Stathatos, Constantin C. Lucas Fernández. A bibliography (15141995). - Reichenberger, Kassel, 1999. 71 pp. II Incipit, 20/21 (200001), 249-250 (Altamiranda).

\section{Fernández de Oviedo, Gonzalo}

53-1076. Carrillo, Jesús - "La teatralización de la verdad en Fernández de Oviedo". - I, 2003, núm. 58, 9-24.

\section{Garcilaso de la Vega}

53-1077. Fernávdez Rodríglez, M. Ayelia - "La mar en medio. Lectura y distancia en un soneto de Garcilaso según Fernando de Herrera". — Edad de Oro, 23 (2004), 369-387.

53-1078. Pego Pligó, Armaxdo - "Hipertextualidad e imitación. (A propósito de los "Espíritus de amor» en Garcilaso)". - RLit, 65 (2003), 5-29.

53-1079. Pineda, Victoria - "El resplandor de Garcilaso (nuevos apuntes para una teoría de los estilos en las Anotaciones de Herrera)". - Criticón, 2003, núms. 87/88/89, 679-688.

V. también núms. 1047. 
Góngora, Luis de

53-1080. Cancelliere, Exrica - "Góngora y Gracián: teoría y práctica de la metáfora”. - Baltasar Gracián: antropología y estética. Actas del II Coloquio Internacional (Berlín, 4-7 de octubre de 2001), ed. S. Neumeister (Berlin, 2004), pp. 281-297.

53-1081. ChafFeE-Sorace, Diane - "Góngora's "Al tronco descansaba de una encina»: An arboretum of political allegory". - RNo, 42 (2001), 73-78.

53-1082. Chemris, Crystal - "A note on female agency and the éfire figure in Góngora's Soledad segunda". - Studies in honor of Denah Lida, eds. M. G. Berg \& Lanin A. Gyurko (Potomac, Maryland, 2005), pp. 96-102.

53-1083. DOLFI, Latra - "El teatro de Góngora: imágenes y enigmas". - Criticón, 2003, núms. 87/88/89, 277-286.

53-1084. Luján Atienza, Ángel Luis "¿Es un soneto de Góngora también una alabanza?". - RLit, 65 (2003), 31-58.

53-1085. Marcos Álvarez, Francisco de B. - "Dificultades conceptistas en el Góngora romanceril: "Trepan los gitanos»". - AEF, 26 (2003), 203-216.

53-1086. Micó, José María - De Góngora. - Biblioteca Nueva, Madrid, 2001. 190 pp. II RFE, 83 (2003), 332-335 (Jauralde Pou).

53-1087. Ponce Cárdenas, Jesís - Góngora y la poesía culta del siglo XVII. - Eds. Laberinto, Madrid, 2001. 246 pp. II RLit, 64 (2002), 622-627 (Bonilla Cerezo).

53-1088. Vicente GarCía, Llis M. - "El lenguaje hermético en la Fábula de Polifemo y Galatea de Góngora". Edad de Oro, 23 (2004), 435-455.

\section{Gracián, Baltasar}

53-1089. Batllori, Miglel - "Medio siglo largo con Gracián”. - Baltasar Gracián: antropología y estética. Actas del II Coloquio Internacional (Berlin, 4-7 de octubre de 2001), ed. S. Neumeister (Berlin, 2004), pp. 13-32.

53-1090. Blanco, Mercedes - "Gracián y el método". - Baltasar Gracián: antro- pología y estética. Actas del II Coloquio Intermacional (Berlin, 4-7 de octubre de 2001), ed. S. Neumeister (Berlin, 2004), pp. 35-61.

53-1091. Caitarino, Elena - "De la anatomía de las pasiones a la antropología de la razón. (Notas sobre las pasiones en Gracián)". - Baltasar Gracián: antropología y estética. Actas del Il Coloquio Intermacional (Berlín, 4-7 de octubre de 2001), ed. S. Neumeister (Berlin, 2004), pp. 159-176.

53-1092. Cantarino, Elena y Emulo BLANCO - "Gracián 2001: balance de un centenario". - Ibero, 2003, núm. 9, 197-208.

53-1093. Egido, Aurora - "El Comulgatorio de Gracián. Lenguaje de los afectos e imágenes visibles". - Baltasar Gracián: antropología y estética. Actas del II Coloquio Internacional (Berlín, 4-7 de octubre de 2001), ed. S. Neumeister (Berlin, 2004), pp. 131-157.

53-1094. EICKHOFF, GeORg - "El cuerpo de Gracián -una interpretación somática del Comulgatorio". - Baltasar Gracián: antropología y estética. Actas del II Coloquio Internacional (Berlin, 4-7 de octubre de 2001), ed. S. Neumeister (Berlin, 2004), pp. 177-190.

53-1095. EmiNowicz, Teresa - "La obra de Baltasar Gracián en Polonia". RLit, 64 (2002), 209-218.

53-1096. Gambin, FeluPE - "La melancolía en El Criticón: manjar de los discretos hacia la Isla de la Inmortalidad". Baltasar Gracián: antropología y estética. Actas del II Coloquio Internacional (Berlín, 4-7 de octubre de 2001), ed. S. Neumeister (Berlin, 2004), pp. 191-212.

53-1097. Hinz, Manfred - "Agudeza y Progymnasmata". - Baltasar Gracián: antropología y estética. Actas del II Coloquio Internacional (Berlin, 4-7 de octubre de 2001), ed. S. Neumeister (Berlin, 2004), pp. 77-95.

53-1098. Kerber, Markus - "El acceso al poder: la estética de la antecámara o Lecciones gracianas de un combatiente". - Baltasar Gracián: antropología y estética. Actas del II Coloquio Internacional (Berlín, 4-7 de octubre de 2001), ed. S. Neumeister (Berlin, 2004), pp. 315-325. 
53-1099. Lasinger, W. - Aphoristik und Intertextualität bei Baltasar Gracián. Eine Strukturanalyse mit subjektgeschichtilchem Ausblick (N. 51-1097). II Ibero, 2003, núm. 11, 244246 (Ehrlicher). - V. núm. 51-2665.

53-1100. Nedmeister, Sebastian - "Sustancia y apariencia: el pavo real de Gracián”. - Baltasar Gracián: antropología y estética. Actas del II Coloquio Internacional (Berlín, 4-7 de octubre de 2001), ed. S. Neumeister (Berlin, 2004), pp. 301-314.

53-1101. Neumeister, Sebastian (ed.) Baltasar Gracián: antropología y estética. Actas del II Coloquio Internacional (Berlin, 4-7 de octubre de 2001). - Edition Tranvía-Verlag Walter Frey, Berlin, 2004. 336 pp.

53-1102. Pelegrín, Benito - "Del efecto al afecto. Gracián, de Lorenzo a Baltasar, de la Agudeza al Comulgatorio". - Baltasar Gracián: antropología y estética. Actas del II Coloquio Internacional (Berlin, 4-7 de octubre de 2001), ed. S. Neumeister (Berlin, 2004), pp. 213-234.

53-1103. PoppenberG, Gerhard - "Pasto del alma-alimento del espíritu. Acercamiento al sistema de la Agudeza". Baltasar Gracián: antropología y estética. Actas del II Coloquio Internacional (Berlin, 4-7 de octubre de 2001), ed. S. Neumeister (Berlin, 2004), pp. 63-75.

53-1104. Strosetzki, Christoph - "Elementos escépticos en Gracián”. Baltasar Gracián: antropología y estética. Actas del II Coloquio Internacional (Berlin, 4-7 de octubre de 2001), ed. S. Neumeister (Berlin, 2004), pp. 237-265.

53-1105. Vaíllo, Carlos - "Tipologías antropológicas y morales en El Criticón". - Baltasar Gracián: antropología y estêtica. Actas del II Coloquio Internacional (Berlín, 4-7 de octubre de 2001), ed. S. Neumeister (Berlin, 2004), pp. 99-129.

V. también núms. 609, 1080.

\section{Guevara, Antonio de}

53-1106. Blanco, Emilio - "De la dignidad a la miseria del hombre en fray Antonio de Guevara". - Íns, 2003, núm. 674, 26-28
Gutiérrez de los Ríos, Francisco, Conde de Fernán Núñez

53-1107. Gutiérrez de los Ríos y CórdoBA, F. - El hombre práctico o Discursos varios sobre su conocimiento y enseñanzas, introd., ed. y notas J. Pérez-Magallón y R. P. Sebold (N. 51-1205). II $R C E H, 26$ (2002), 560-561 (Kamen).

\section{Herrera, Fernando de}

V. núms. 1077, 1079 .

\section{Jáuregui, Juan de}

53-1108. Rico García, José Manuel - La perfecta idea de la altísima poesía. Las ideas estéticas de Juan de Jáuregui. - Diputación, Sevilla, 2001. 300 pp. II RLit, 65 (2003), 617-621 (Alburquerque García).

\section{Las Casas, fray Bartolomé de}

53-1109. García, Gustavo V. - "La invención "ética» del sujeto indígena en la Brevisima relación de la destruición de las Indias". - Ibero, 2003, núm. 12, 7-24.

\section{Lazarillo de Tormes}

53-1110. Alatorre, Antonio - "El Lazarillo y Alfonso de Valdés". - NRFH, 52 (2004), 143-151.

53-1111. Baras Escolá, Alfredo - "Laza rillo y su autor: ¿Alfonso de Valdés o Lope de Rueda?”. - Íns, 2003, núm. 682, 13-16.

53-1112. Carrasco, Félix - "Lazarillo: «(..) hablando con reverencia de Vuestra Merced, porque está ella delante" y la autoría de Alfonso de Valdés". - Íns, 2003, núm. 683, 14-17.

53-1113. Ruffinatto, Aldo - "Lázaro González Pérez, actor y autor del $L a$ zarillo". - Íns, 2003, núm. 683, 11-13.

53-1114. Zimic, STANisL.AV - Apuntes sobre la estructura paródica y satírica del "La- 
zarillo de Tormes". - Iberoamericana, Madrid, 2000. 128 pp. II Ibero, 2003, núm. 9, 223-225 (Ehrlicher).

V. también núm. 1034.

\section{León, fray Luis de}

53-1115. KotTMan, Karl A. - "A trace of Aristotle: M. A. Camós on Luis de León”. - CD, 217 (2004), 515-526.

\section{Lizárraga, Reginaldo de}

53-1116. Tieffemberg, Silvia - "Escribir los caminos. La construcción del espacio en la Descripción breve... de Reginaldo de Lizárraga". - Ibero, 2003, núm. 10, 37-56.

\section{López de Ayala, Diego}

53-1117. Muñiz MuÑiz, María de las NieVEs - "Sobre la traducción española del Filocolo de Boccaccio (Sevilla 1541) y sobre las Treize elegantes demandes d'amours". - Criticón, 2003, núms. 87/88/89, 537-551.

\section{López de Úbeda, Francisco}

53-1118. BODENMÜLLER, T. - Literaturtransfer in der Frühen Neuzeit. Francisco López de Úbedas "La picara Justina" und ihre Italienische und Englische Bearbeitung von Barezzo Barezzi und Captain John Stevens (N. 51-2691). II Ibero, 2003, núm. 10, 199-200 (Ehrlicher).

\section{Matos Fragoso, Juan de}

53-1119. Mata Induráin, Carlos - "Burlas carnavalescas a don Quijote en $E l$ hidalgo de la Mancha, comedia de tres ingenios". - SLL, 5 (2003), núm. 2, $51-71$

\section{Montemayor, Jorge de}

53-1120. Miñana, Rogelio - "Verosimilitud en la Arcadia: el decoro en $L a$ Diana, La Galatea y Don Quijote I:12". - RCEH, 26 (2002), 455-474.

Núñez Cabeza de Vaca, Alvar

53-1121. Agnew, Michaer - "Zarzas, calabazas y cartas de relación: el triple peregrinaje imperialista de Alvar Núñez Cabeza de Vaca (Jerusalén, Compostela y Roma)". - RCEH, 27 (2003), 217-240.

\section{Núñez de Miranda, Antonio}

53-1122. Alatorre, Antonio - "Sobre el P. Núñez, confesor de sor Juana (a propósito de dos libros recientes)". - LMM, 14 (2003), 7-22.

\section{Núñez de Toledo y Guzmán, Hernán}

53-1123. Signes Codoner, Juan, Carmen Codoner Merino y Arantxa Domngo Malvadi - Biblioteca y epistolario de Hernán Núñez de Guzmán (El Pinciano): una aproximación al humanismo español del s. XVt. - CSIC, Madrid, 2001. 558 pp. II RLit, 64 (2002), 260-264 (Gómez Álvarez).

\section{Olmedo, Alonso de}

53-1124. Granja, Agustíx dE LA - "El hato de Olmedo empeñado en Sevilla". - Criticón, 2003, núms. 87/88/89, 379-381.

\section{Ordóñez de Ceballos, Pedro}

53-1125. Zugasti, Miglfi_ - "El Viaje del mundo (1614) de Pedro Ordóñez de Ceballos o cómo modelar una autobiografia épica". - I, 2003, núm. 58, 83-119 
Oña, Pedro de

53-1126. Mazzottr, José Antonio - "El mirador criollo: secretos de la Araucanía y la autoridad del testigo en Pedro de Oña". - I, 2003, núm. 58, 171-196.

\section{Ortega, Melchor de}

V. núm. 602.

\section{Palmerín de Olivia}

53-1127. González, Javier Roberto - "El sistema profético en la determinación del Palmerin-Primaleón como unidad textual (segunda y última parte)". - Incipit, 20/21 (2000-01), 81-118.

\section{Pérez de Oliva, Fernán}

53-1128. Baranda, Consolación - "De Pérez de Oliva a Cervantes de Salazar: homenaje y traición". - Íns, 2003, núm. 674, 22-25.

53-1129. Rico, Fraxcisco - "Que sólo un punto parece". - Íns, 2003, núm. 674, 20-21.

V. también núm. 647.

\section{Pizarro, Francisco}

53-1130. MARrero-Fente, RAĹl - "Épica, historia y verdad en La conquista del Perú (1538)". - I, 2003, núm. 58, 120-133.

\section{Poma de Ayala, Felipe Guamán}

\section{3-1131. Cabos Fontana, Marie-Clalde} - Mémoire et acculturation dans les Andes, Guaman Poma de Ayala et les influences européennes. Préf. de François Chevalier. - L'Harmattan, Paris, 2000. 275 pp. II Carav, 2002, núm. 79, 283-285 (Bertrand).
53-1132. Chang-Rodríguez, RaQuel "Virreyes virtuosos? El juicio de Guamán Poma de Ayala”. - I, 2003, núm. 58, 25-48.

\section{Quevedo y Villegas, Francisco}

53-1133. Álvarez de Miranda, Pedro "Quevedo en la lexicografía española". - Edad de Oro, 23 (2004), 389416.

53-1134. Arellano, Ignacio y Victoriano RonCERo - La musa Clío del "Parnaso español" de Quevedo. - EUNSA, Pamplona, 2001. 215 pp. II RLit, 64 (2002), 269-271 (Plata).

53-1135. Crosby, James O. - La tradición manuscrita de los "Sueños" de Quevedo y la primera edición. - Purdue University Press, West Lafayette, 2005. 132 pp. (Purdue Studies in Romance Literatures, 31).

53-1136. Galván Moreno, Lurs - El "Poema heroico a Cristo resucitado" de Francisco de Quevedo: análisis e interpretación. EUNSA, Pamplona, 2004. 119 pp. (Anejos de "La Perinola", 15).

53-1137. García Santo-Tomás, EnriQue "Cultura material y fetiches quevedescos". - Edad de Oro, 23 (2004), 417-433.

53-1138. Gaylord, Mary M. - "Intimacy and allegory in a Quevedo sonnet ( En breve cárcel traigo aprisionado")". - Studies in honor of Denah Lida, eds. M. G. Berg \& Lanin A. Gyurko (Potomac, Maryland, 2005), pp. 103-112.

53-1139. Profeti, Maria Grazla — " "Yo vi la grande y alta jerarquía»: el tema de las ruinas en Quevedo". - Criticón, 2003, núms. 87/88/89, 709-718.

53-1140. Vrvar, F. - Quevedo y su España imaginada (N. 52-991). II RCEH, 27 (2003), 606-608 (Clamurro).

\section{Quiñones de Benavente, Luis}

53-1141. Quiñones de. Bexavente, Llis Entremeses completos. T. 1: Jocoseria. Ed. de I. Arellano, J. M. Escudero y A. Madroñal Durán. - Universidad de 
Navarra-Iberoamericana-Vervuert, Pamplona-Madrid-Frankfurt/M., 2001. 750 pp. II RLit, 65 (2003), 621623 (Castilla Pérez).

\section{Rodríguez Freile, Juan}

53-1142. Folger, Robert - "Cien años de burocracia: $E l$ carnero de Juan Rodriguez Freyle". - - I, 2003, núm. 58, 49-61

\section{Rojas Zorrilla, Francisco de}

53-1143. Pedraza Jiménez, Felipe B. "Abrir el ojo de Rojas Zorrilla bajo el Antiguo régimen". - Criticón, 2003, núms. 87/88/89, 637-648.

53-1144. Pedraza Jiménez, Felipe B. - "La comedia española como yuxtaposición de estilos. El caso de Rojas Zorrilla". — Edad de Oro, 23 (2004), 339-354.

\section{Rueda, Lope de}

53-1145. Hermenegildo, Alfredo "Usos de la metateatralidad: los pasos de Lope de Rueda". - SLL, 5 (2003), núm. 2, 13-31.

V. también núm. 1111.

\section{Ruiz de Alarcón, Juan}

53-1146. González, Serafín - "Apariencia y realidad en $L a$ verdad sospechosa". - SLL, 5 (2003), núm. 2, 95-103.

53-1147. Goxzález, Serafix - "El problema del protagonismo dramático en Los empeños de un engaño". - SLL, 5 (2003), núm. 1, 217-226.

53-1148. JosA, Loi A - "Hacia el pensamiento de Juan Ruiz de Alarcón". RLit, 64 (2002), 413-435.

V. también núm. 1041.

\section{Salazar y Torres, Agustín de}

53-1149. Salazar y Torres, A. DE - Elegir al enemigo, ed. T. Austin O'Connor
(N. 51-1159). I NRFH, 52 (2004), 207-213 (Alatorre).

\section{Sánchez de Badajoz, Diego}

53-1150. Cazal, Françorse - Dramaturgia y reescritura en el teatro de Diego Sánchez de Badajoz. - Presses Universitaires du Mirail, Toulouse, 2001. 672 pp. II Ibero, 2003, núm. 10, 193-194 (Serrano Deza).

\section{Sigüenza y Góngora, Carlos de}

53-1151. Flesler, Daniela - "Contradicción y heterogeneidad en Infortunios de Alonso Ramírez de Carlos Sigüenza y Góngora". - RNo, 42 (2002), 163169.

\section{Silva, Feliciano de}

53-1152. Martín Lalanda, Javier - "Temas y motivos de origen maravilloso en Feliciano de Silva: la Parte tercera de la Crónica de Florisel de Niquea (Sevilla, 1546)". - BICC, 54 (1999), 217-238.

\section{Tassis y Peralta, Juan de, Conde de Villamediana}

53-1153. Matas Caballero, Juan - "Un comentario sobre la poesía del exilio del Conde de Villamediana, «Al retiro de las ambiciones de la Corte»". $E H F, 26$ (2004), 203-217.

\section{Teresa de Jesús}

53-1154. Astigarragi, Jean Llis y Agt stín BORRELL - Concordancias de los escritos de Santa Teresa de Jesús. - Editoriales O.C.D., Roma, 2000.2 ts.: 3054 pp. II Incipit, 22 (2002), 246-248 (Lastra Paz).

53-1155. Herpoel, S. - A la zaga de Santa Teresa. Autobiografias por mandato (N. 50-2100). II RLit, 64 (2002), 617-622 (Manero Sorolla). 
53-1156. Marín Pina, M. Carmen - "El caballero de Ávila y las fiestas zaragozanas por la beatificación y canonización de Santa Teresa en el siglo Xviı". - BICC, 54 (1999), 155-179.

\section{Tirso de Molina}

53-1157. Molina, TIRso DE - La villana de Vallecas. Ed. crítica, est. y notas de Sofía Eiroa. - Instituto de Estudios Tirsianos, Madrid-Pamplona, 2001. 299 pp. II RLit, 64 (2002), 271-273 (Díez de Revenga).

53-1158. Arellano, Ignacio - Arquitecturas del ingenio. Estudios sobre el teatro de Tirso de Molina. - Universidad de Navarra-Revista Estudios-GRISO, Madrid-Pamplona, 2001. 336 pp. II RLit, 65 (2003), 623-627 (Quinziano).

53-1159. Arellano, Ignacio - "El burlador de Sevilla”. - Íns, 2003, núm. 681, 27-28.

53-1160. Arellano, Ignacio - "La comedia de capa y espada de Tirso o el dominio del ingenio". - Ins, 2003, núm. 681, 14-17.

53-1161. Di Stefano, Giuseppe - "Anotaciones al texto del Burlador de Sevilla". - Criticón, 2003, núms. 87/88/89, 251-263.

53-1162. Dolfi, Laura y Eva Galar (eds.)

- Tirso de Molina: textos e intertextos.

- Instituto de Estudios Tirsianos, Pamplona-Madrid, 2002. 350 pp. II RLit, 65 (2003), 287-289 (Rodríguez Rípodas).

53-1163. Escudero Baztán, Lara - "La comedia hagiográfica de Tirso de Molina”. - Ins, 2003, núm. 681, 20-23.

53-1164. Florit Durán, Francisco - "El sistema dramático de Tirso de Molina”. - Íns, 2003, núm. 681, 10-14.

53-1165. Friedman, EdWard H. - "Resonancias cervantinas en El vergonzoso en palacio". -Ins, 2003, núm. 681, 17-20.

53-1166. Galoppe, R. A. - Género y confusión en el teatro de Tirso de Molina (N. 49-2508). II NRFH, 52 (2004), 203207 (Soons); RCEH, 27 (2003), 374376 (Stoll). - V. núm. 52-1001.

53-1167. OTEIZA, BlancA - "Tirso en el siglo xxi: estado actual de los estudios tir- sianos (I)". - Ins, 2003, núm. 681, 3-5.

53-1168. Palomo, María del Pilar "Tirso, prosista". - Íns, 2003, núm. 681, 30-32.

53-1169. Parker Aronson, Stacey L. "La poligamia de Don Juan Tenorio: El burlador de Sevilla como argumento contra el matrimonio clandestino". - RNo, 43 (2002), 53-63.

53-1170. Pedraza Jiménez, Felipe B. "Tirso en escena. Recuerdos de un espectador". - İns, 2003, núm. 681, 29-30.

53-1171. Restrepo Gautier, P. - La imaginación emblemática en el drama de Tirso de Molina. II RCEH, 27 (2003), 602-603 (Albrecht). [49-2510].

53-1172. Rodriguez López VÁzQuez, A. Tirso, Lope, Claramonte. La autoria de las comedias más famosas del Siglo de Oro (N. 51-2730). II Incipit, 20/21 (200001), 250-252 (Altamiranda).

53-1173. VÁzquez Fernández, Luis "Biografía de Tirso de Molina (15791648): estado actual de la cuestión". - Ins, 2003, núm. 681, 7-10.

53-1174. Zugasti, Miguel - "El drama histórico de Tirso de Molina". - Íns, 2003, núm. 681, 23-26.

\section{Torre, Francisco de la}

53-1175. Pérez-Abadín Barro, Soledad "Al margen de las Obras de Francisco de la Torre". - RLit, 65 (2003), 375-390.

\section{Valadés, Diego}

53-1176. Tovar Paz, Francisco Javier "El recurso al «exemplum» en el libro tercero de la Rhetorica Christiana de fray Diego de Valadés". - AEF, 26 (2003), 407-422.

\section{Valdés, Alfonso de}

53-1177. Navarro, Rosa - "La profesión como arte: la dignidad del hombre en los diálogos de Alfonso de Valdés". - Íns, 2003, núm. 674, 18-20.

V. también núms. 1110-1112. 
Valdés, Juan

V. núm. 122.

Vargas, Bermardo de

53-1178. VARGas, Bernardo de - Cirongilio de Tracia. Ed. de Javier Roberto González. - Centro de Estudios Cervantinos, Alcalá de Henares, 2004. 513 pp. (Los Libros de Rocinante, 17).

\section{Vega Carpio, Lope de}

53-1179. VEGA, L. DE - El rey don Pedro en Madrid y el Infanzón de Illescas. Attributed to Lope de Vega, ed. C. Bingham Kirby (N. 48-2704). II Incipit, 22 (2002), 242-244 (Altamiranda). - V. núm. 51-2735.

53-1180. Amselem-SzeNde, LNe - "Encarnación de Lope de Vega en los Soliloquios amorosos de un alma a Dios". - Criticón, 2003, núms. 87/88/89, 19-34.

53-1181. ANTonLcCi, FaUsTa - "El perro del hortelano y La moza de cántaro: un caso de auto-reescritura lopiana". - Criticón, 2003, núms. 87/88/89, 47-57.

53-1182. Canavaggio, Jeai - " "Frescos vientos de Madrid..."”. - Criticón, 2003, núms. 87/88/89, 125-128.

53-1183. Cornejo, Manuel — "Reflexiones sobre la funcionalidad del espacio urbano en $\mathrm{El}$ acero de Madrid de Lope de Vega". - Criticón, 2003, núms. 87/88/89, 175-187.

53-1184. Colderc, Christopher - "Sobre el sistema de los personajes de El acero de Madrid, de Lope de Vega". - Criticón, 2003, núms. 87/88/89, 189-199.

53-1185. CúlLLaR, Donaji - "Presencia de la tradición medieval en La serrana de la Vera de Luis Vélez de Guevara y Las dos bandoleras de Lope de Vega". - Literatura y conocimiento medieval. Actas de las VIII Jornadas Medievales, eds. L. von der Walde, C. Company y A. González (México, 2003), pp. 149-165.

53-1186. Étientre, Jean-Pierre - "Lope "fiscal de la lengua" en La Dorotea, o las dos patrias del Fénix". - Edad de Oro, 23 (2004), 295-309.
53-1187. García Lorenzo, Luciano - " $E l$ acero de Madrid: de las puestas en escena a la edición de Arata". - Criticón, 2003, núms. 87/88/89, 325-332.

53-1188. Garcia Santo-TOMÁs, ENriole La creación del "Fénix". Recepción crítica y formación canónica del teatro de Lope de Vega. - Gredos, Madrid, 2000. 429 pp. II RCEH, 27 (2003), 376-378 (McKendrick).

53-1189. Garrot Zambrana, Juan Carlos - "Gerineldo en los tablados: amor y medro en Lope de Vega y Gaspar Aguilar". - Criticón, 2003, núms. $87 / 88 / 89,333-345$.

53-1190. Gómez Sierra, Esther - “ $L a d a$ ma boba, la autoridad y Stefano Arata, autore". - Criticón, 2003, núms. 87/88/89, 359-378.

53-1191. Marchante, Carmen - "El «Capitano" Fracasso en la toma de Granada: una adaptación napolitana de Lope". - Criticón, 2003, núms. 87/88/89, 459-468.

53-1192. Martínez-Berbel, JLan Antonio - " "Puso el honor dragones de Medea". Sobre ésta y otras Medeas en el teatro de Lope”. - Criticón, 2003, núms. 87/88/89, 479-492.

53-1193. MASCIA, MARK J. - "De/reconstructing appearances: Lope de Vega's inversion of female beauty in the Rimas humanas y divinas del Licenciado Tomé Burguillos". — RNo, 42 (2002), 313-322.

53-1194. McKendrick, M. - Playing the king. Lope de Vega and the limits of comformity (N. 50-2413). II RCEH, 27 (2003), 387-389 (Pérez Magallón); $R F, 115$ (2003), 405-406 (Reichenberger); Ibero, 2003, núm. 10, 197-198 (Simson). - V. núm. 52-1016.

53-1195. McNair, Aiexander J. - "Reconsidering the didacticism of Lope de Vega's Arcadia". - RNo, 42 (2001), 97-105.

53-1196. Ol.F.A, JOAN - "El Lope de los últimos años y la materia palatina". - Criticón, 2003, núms. 87/88/89, 603-620.

53-1197. Pastexa, Enrico di - "Hacia una edición crítica de La hermosura aborrecida de Lope de Vega". - Criticón, 2003, núms. 87/88/89, 239-249. 
53-1198. Penas IbáNez, M. AzuceNa - "El significado del lenguaje figurado en Lope de Vega". - Edad de Oro, 23 (2004), 311-337.

53-1199. Presotto, Marco - "La tradición textual de La ilustre fregona atribuida a Lope de Vega". - Criticón, 2003, núms. 87/88/89, 697-708.

53-1200. Profeti, Maria Grazia - Per una bibliografia di Lope de Vega. Opere non drammatiche a stampa. - Reichenberger, Kassel, 2002. 462 pp. II RLit, 65 (2003), 285-287 (Hernández Durán).

53-1201. Redondo, Augustrn - "Teatralidad, trayectoria narrativa y recorrido ideológico en una novela de Lope de Vega, La prudente venganza". - Criticón, 2003, núms. 87/88/89, 733-744.

53-1202. Saivo, Mimma de - "Sobre el reparto de El tirano castigado, de Lope de Vega". - Criticón, 2003, núms. $87 / 88 / 89,215-226$.

53-1203. Serralta, FrÉdÉric - "Sobre el "pre-figurón" en tres comdeias de Lope (Los melindres de Belisa, Los hidalgos de la aldea y El ausente en el lugar)". - Criticón, 2003, núms. 87/88/89, 827-836.

53-1204. Tedesco, ANA - " "All'usanza spagnolla»: el Arte nuevo de Lope de Vega y la ópera italiana del siglo xvi". - Criticón, 2003, núms. 87/88/89, $855-863$.

53-1205. VAccari, D. - "Edición de una pieza inédita y de su plan en prosa: el Entremés del paño". - Criticón, 2003, núms. 87/88/89, 877-885.

53-1206. Vassalli, PaOla - "El laberinto de Creta y su pórtico literario". AION-R, 45 (2003), 507-516.

V. también núms. 610, 639, 680, 1172.

Vélez de Guevara, Luis

53-1207. Correa, Pedro - "Recursos lingüísticos utilizados por L. Vélez de Guevara en El príncipe viñador". AFF, 26 (2003), 57-77.

V. también núm. 1119.

Vera Tassis y Villaroel, Juan de
Vicente, Gil

53-1208. BlaCKMORE, JOSIAH - "Laughing between the lines in Gil Vicente's $A u$ to de Inês Pereira". - RCEH, 27 (2003) , 435-445.

53-1209. Grande Quejigo, Francisco JaVIER - "La representación de la liturgia de la Pasión y Resurrección en el teatro de Gil Vicente". - AFF, 26 (2003), 171-188.

\section{Virués, Cristóbal de}

53-1210. Froldi, Rinaldo - "La legendaria reina de Asiria. Semíramis, en Virúes y Calderón”. - Criticón, 2003, núms. 87/88/89, 315-324.

53-1211. Hermenegildo, Alfredo "Cristóbal de Virués y la figura de Felipe II". - Criticón, 2003, núms. $87 / 88 / 89,395-406$.

\section{Vives, Juan Luis}

53-1212. Olivares Zorrilla, Rocío "Versiones hispánicas del Tratado del alma aristotélico: Juan Luis Vives y Alonso de la Veracruz". - LMM, 14 (2003), 163-178.

53-1213. Serés, Guillermo - "La Fabula de homine, de Juan Luis Vives, en su tradición". - Ins, 2003, núm. 674, 15-18.

\section{Zayas Sotomayor, Maria de}

53-1214. BrownleE, M. S. - The cultural labyrinth of Maria de Zayas (N. 521026). II Ibero, 2003, núm. 9, 227-229 (Jung).

53-1215. Romero-Díaz, Nieves - "En los límites de la representación: la traición de María de Zayas". - RCEH, 26 (2002), 47. -492 .

Zuazo, Alonso de

53-1216. ZuAzo, Alovso de - Cartas y memorias (1511-1539). Ed. de R. Martí-

V. núm. 996. 
nez Baracs. - CONACULTA, México, 2000. 414 pp. II Carav, 2002, núm. 79, 277-278 (Grunberg).

\section{SIGLO XVIII}

\section{Abad, Diego José}

53-1217. Abad, Diego JosÉ - Disertación joco-seria: si alguien nacido fuera de Italia puede escribir correctamente el latin, en contra de lo que opina Roberti. Introd., trad. y notas de Roberto Heredia Correa. - Universidad Autónoma de Aguascalientes, Aguascalientes, 2000. xlv + $20+20$ pp. II LMM, 13 (2002), 280-283 (Reyes Coria).

\section{Cadalso, José de}

53-1218. Cadalso, J. DE - Cartas marruecas. Noches lúgubres, ed. E. Martínez Mata; est. prelim. N. Glendinning (N. 49-2546). II RCEH, 27 (2003), 563-565 (Iarocci); RLit, 64 (2002), 279-281 (Suárez-Galbán).

53-1219. CADALSO, J. DE - Cartas marruecas. Noches lúgubres, ed. R. P. Sebold (N. 42-1500). II RCEH, 27 (2003), 565-567 (Lama). - V. núm. 52-1028.

53-1220. Durán López, Fernando - "La autobiografía juvenil de José Cadalso". - RLit, 64 (2002), 437-473.

\section{Cañizares, José de}

53-1221. CaÑIzARES, JosÉ DE - La ilustre fregona. Introd., testo critico e note di Marco Presotto. - Panezzo Editore, Rimini, 2001. 252 pp. II RLit, 64 (2002), 281-283 (Garelli).

\section{Eguiara y Eguren, Juan José de}

53-1222. Higgrns, A. - Constructing the criollo archive. Subjects of knowledge in the "Biblioteca mexicana" and the "Rusticatio mexicana" (N. 49-2568). II RCEH, 27 (2003), 378-380 (Alba-Koch).
Fernández de Moratín, Leandro

53-1223. López RoMero, JosÉ - "El manuscrito jerezano de La mojigata, comedia de Leandro Fernández de Moratín". - RLit, 65 (2003), 391412.

53-1224. Rodriguez, Juan Carlos - "Los comienzos del criticismo moderno. (Los gusanos de seda de Hume, la hoja de parra de Kant y el taquígrafo de Moratín)". - Historia literarial Historia de la literatura, ed. L. Romero Tobar (Zaragoza, 2004), pp. 45-66.

\section{Gálvez de Cabrera, Maria Rosa}

53-1225. Gálvez, M. R. - La familia a la moda, ed. R. Andioc (N. 50-2425). II RLit, 64 (2002), 283-285 (Angulo). V. núm. 51-1202.

\section{Isla, José Francisco de}

53-1226. HaInT, R. - Seduction and sacrilege. Rhetorical power in "Fray Gerundio de Campazas" (N. 52-2747). II RLit, 65 (2003), 630-635 (Sánchez Llama).

\section{Landivar, Rafael}

V. núm. 1222.

\section{Luzán y Claramunt, Ignacio}

53-1227. De Cesare, Giovanni B. - "Ignacio de Luzán en Palermo (172329). (Una oración inédita y unas rimas olvidadas en lengua italiana)". AION-R, 45 (2003), 285-340.

\section{Meléndez Valdés, Juan}

53-1228. Ramajo Caño, Antonio - "Aspectos del sustrato clásico en la poesía de Meléndez Valdés". - RLit, 64 (2002), 41-61. 
Samaniego, Félix Maria de

53-1229. Palacios Fernández, E. (coord.) - Félix María de Samaniego y la literatura de la Ilustración (N. 52-2756). II RLit, 64 (2002), 276-278 (Romero Peña).

\section{Sarmiento, fray Martin}

53-1230. Sarmiento, Martín - Sistema de adornos del Palacio Real de Madrid. Ed., introd. y notas de Joaquín Álvarez Barrientos y Concha Herrero Carretero. - Sociedad Estatal de Conmemoraciones Culturales, Madrid, 2002. 449 pp. II RLit, 65 (2003), 294-300 (Vega).

\section{SIGLO XIX}

\section{Alas, Leopoldo "Clarín"}

53-1231. Alas, leopoldo "Clarín" Cuentos completos. Ed. de Carolyn Richmond. - Alfaguara, Madrid, 2000.2 ts.: $551+710$ pp. II RCEH, 27 (2003), 355-357 (Iarocci).

53-1232. Deaver, William D. JR. — "Lo religioso en un cuento de Clarín". $R N o, 43$ (2002), 91-97.

53-1233. Núñez Puentes, Sonia - Ellas se aburren. Ennui e imagen femenina en "La Regenta" y la novela europea de la segunda mitad del XIX. - Universidad, Alicante, 2001. 288 pp. II RLit, 65 (2003), 646-650 (Sáez Martínez).

53-1234. Rubio Jiménez, Jesús - "En torno a un cuento de Clarín: Reflejo. Confidencias". - RLit, 64 (2002), 93-106.

53-1235. VAl.IS, NOËL - Leopoldo Alas (Clarin). An annotated bibliography. Suplement I. - Tamesis, London, 2002. 394 pp. II BIEA, 57 (2003), 257 259 (Martínez Cachero).

V. también núm. 1489.

\section{Altamirano, Ignacio $M$.}

53-1236. Conway, Christopher - "Próspero y el teatro nacional: encuentros transatlánticos en las revistas teatrales de Ignacio Manuel Altamirano, $1867-$ 1876". - Ibero, 2003, núm. 9, 147-159. 53-1237. Cortázar, Alejandro - "El Zarco de Ignacio Manuel Altamirano: la figura del charro y la epopeya que no fue". - $T C, 2003$, núm. 12, 95-115.

\section{Arenal, Concepción}

53-1238. Simón Palmer, María del Carmen - Arenal y Lázaro. La admiración por una mujer de talento (1889-1895). Fundación Lázaro Galdiano-Ollero y Ramos, Madrid, 2002. 112 pp. II RLit, 65 (2003), 310-314 (Fernández).

\section{Badía Leblich, Domingo}

53-1239. Badía, D. (ALí Bey) - Alí Bey en Marruecos. Tragedia en cinco actos, ed., est. y notas de C. C. García Valdés y M. McGaha (N. 52-2761). I RLit, 64 (2002), 285-287 (Almarcegui).

\section{Cambaceres, Eugenio}

53-1240. Conway, Christopher - "Cambaceres meets Schopenhauer: The ontology of despair in Sin rumbo (1885)". - RNo, 43 (2002), 65-73.

53-1241. Spicer-Escalante, Juan Pablo "A non imperial eye/I: Europe as contact zone in Eugenio Cambaceres's Música sentimental (1884)". - Brújula, 3 (2004), núm. 1, 53-68.

\section{Campo, Ángel de}

53-1242. Torres-Pou, JUan - "Técnicas y discurso criminológico en el porfiriato: el caso de La Rumba de Angel de Campo". - Ibero, 2003, núm. 9, 27-36.

\section{Castera, Pedro}

53-1243. Chouciño Fernández, Ana y Leticla Algaba - "Lectores y lecturas de Carmen, de Pedro Castera". LMM, 14 (2003), 87-111. 


\section{Dario, Rubén}

53-1244. Darío, RUBÉN - La caravana pasa. Libro cuarto y libro quinto y último. Ed. crítica, introd. y notas de Günther Schmigalle. - Academia Nicaragüense de la Lengua-Edition Tranvia-Walter Frey, Managua-Berlin, 2004. 300 pp.

53-1245. ACEREDA, AIberTo - "A comparative reading of Hispanic modernism: Darío's knowledge of Schopenhauer". - RNo, 43 (2003), 181-192.

53-1246. ACEREDA, Alberto - "Dos visiones del espacio marino como modernidad. Entre la poesía de Rubén Darío y la pintura de Joaquín SoroIla". - RLit, 65 (2003), 119-143.

53-1247. Bourne, L. - Fuerza invisible. Lo divino en la poesía de Rubén Dario (N. 50-2461). II RCEH, 26 (2002), 551-553 (Lodato).

53-1248. Morrow, JoHN A. - "Darío's «A Bolivia»: Cosmic correspondences and universal analogies". - RNo, 44 (2003), 113-115.

V. también núm. 1532.

\section{Espronceda, José de}

53-1249. Ramajo Caño, Antonio - "El sustrato horaciano en un poema romántico: la Canción del pirata de Espronceda". - AEF, 26 (2003), 325334.

\section{Fernández de Lizardi, José Joaquín}

53-1250. FernáNdEZ de LizARdi, José JoAQUín - Don Catrín de la Fachenda y Noches tristes y dia alegre. Ed. de Rocío Oviedo y Almudena Mejías. - Cátedra, Madrid, 2001. 239 pp. II LMM, 13 (2002), 271276 (Palazón Mayoral).

53-1251. Alвa-Koch, B. - Ilustrando la Nueva España: texto e imagen en "El Periquillo Samiento" de Fernández de Lizardi (N. 51-2785). II RCEH, 26 (2002), 553-555 (Williams).

53-1252. Flores, ENRIQLE - "Lizardi y la voz o cuando los pericos mamen". Ibero, 2003, núm. 10, 57-66.
53-1253. Porras Collantes, Ernesto "Definición e indefinición del personaje en El Periquillo Samiento". BICC, 53 (1998), 90-97.

53-1254. Vogeley, N. - Lizardi and the birth of the novel in Spanish America (N. 52-1059). II RCEH, 27 (2003), 401403 (Alba-Koch).

V. también núm. 1298.

\section{Gamboa, Federico}

53-1255. Clriet., Fernando - "Santa: el desenlace vedado". - Santa, Santa nuestra, ed. R. Olea Franco (México, 2005), pp. 51-68.

53-1256. Diaz Ruiz, Ignacio - "Santa: una presencia literaria en Hispanoamérica". - Santa, Santa nuestra, ed. R. Olea Franco (México, 2005), pp. 273-285.

53-1257. Domenella, Ana Rosa - "Del canon a la parodia: posible diálogo entre Santa y la Diablesa". - Santa, Santa nuestra, ed. R. Olea Franco (México, 2005), pp. 287-302.

53-1258. Glantz, Margo - "Santa, ¡otra vez!". - Santa, Santa nuestra, ed. R. Olea Franco (México, 2005), pp. 125-134.

53-1259. González, AvíbaI - "Santidad y abyección en Santa". - Santa, Santa nuestra, ed. R. Olea Franco (México, 2005), pp. 111-124.

53-1260. González Reyes, Alba H. "Los ritos de paso y las imágenes eróticas: dos lecturas en Santa". - Santa, Santa nuestra, ed. R. Olea Franco (México, 2005), pp. 329-352.

53-1261. Gutiérrez de Velasco, Luzelena - "En busca de las "curvas de indiferencia» en Santa". - Santa, Santa nuestra, ed. R. Olea Franco (México, 2005), pp. 321-328.

53-1262. L lidder, María Fervanda - "La mirada de Hipólito”. - Santa, Santa nuestra, ed. R. Olea Franco (México, 2005), pp. 305-319.

53-1263. LoREnZANO, SANDRA - “"Ella no era una mujer, era una...»". - Santa, Santa nuestra, ed. R. Olea Franco (México, 2005), pp. 181-188.

53-1264. Martínez Suárez, José Luis - 
"Génesis y recepción contemporánea de Santa: 1897-1904". - Santa, Santa nuestra, ed. R. Olea Franco (México, 2005), pp. 37-50.

53-1265. Munglia Zatarain, Martha Ele$\mathrm{NA}$ - "El derrumbe del idilio en Santa. Problemas de interacción discursiva en la novela". - Santa, Santa nuestra, ed. R. Olea Franco (México, 2005), pp. 71-89.

53-1266. Negrín, María Eugenta - "La conmoción de la caída. Intratexto e inframundos de Gamboa”. - Santa, Santa nuestra, ed. R. Olea Franco (México, 2005), pp. 91-109.

53-1267. Olea Franco, Rafael - "La construcción de un clásico: cien años del mito de Santa". - Santa, Santa nuestra, ed. R. Olea Franco (México, 2005), pp. 13-36.

53-1268. Olea Franco, Rafael (ed.) Santa, Santa nuestra. - El Colegio de México, México, 2005. 363 pp. (Serie Literatura Mexicana, 8).

53-1269. PiNeda Franco, Adela "«¿Qué quieres que te regale cuando te mueras?" La muerte de una bella mujer sobre el mapa de la ciudad". - Santa, Santa nuestra, ed. R. Olea Franco (México, 2005), pp. 171-180.

53-1270. Prendes, Mandel - "Teatralidad y simbolismo: acerca de la configuración del espacio en las novelas de Gamboa". - Santa, Santa nuestra, ed. R. Olea Franco (México, 2005), pp. 353-363.

53-1271. Quintana Tejera, Luis - "Encuentro y diálogo de corrientes decimonónicas en Santa". - Santa, Santa nuestra, ed. R. Olea Franco (México, 2005), pp. 191-208.

53-1272. Quirarte, Vicente - "Retorno a los santos lugares". - Santa, Santa nuestra, ed. R. Olea Franco (México, 2005), pp. 137-144.

53-1273. Rodriguez GoNzillez, Yliana "El tópico en Santa". - Santa, Santa nuestra, ed. R. Olea Franco (México, 2005), pp. 209-221.

53-1274. Sandoval, Adruavi - "Santa: un melodrama disfrazado de naturalismo". - Santa, Santa nuestra, ed. R. Olea Franco (México, 2005), pp. 223-238.
53-1275. Schlichers, SABINE - "Santa, texto fundador ambivalente de la patria mexicana". - Santa, Santa nuestra, ed. R. Olea Franco (México, 2005), pp. 145-158.

53-1276. Solomon, Glaire - ¿Cuánto cuesta el presente? El tiempo de la prostitución en Santa". - Santa, Santa nuestra, ed. R. Olea Franco (México, 2005), pp. 159-170.

53-1277. Uribe, Álvaro - "Historia de dos beldades". - Santa, Santa nuestra, ed. R. Olea Franco (México, 2005), pp. 241-253.

53-1278. Vital, Auberto - "Santa: un éxito en el México porfirista”. — Santa, Santa nuestra, ed. R. Olea Franco (México, 2005), pp. 263-272.

V. también núm. 604.

\section{Ganivet, Ángel}

53-1279. Á INAREz Castro, L. - El universo femenino de Ángel Ganivet. - Diputación de Granada-Fundación Caja de Granada, Granada, 1999. 319 pp. II RCEH, 26 (2002), 546-548 (Santiánez).

53-1280. Gantvet, A. - El escultor de su alma y otros textos dramáticos, eds. R. de la Fuente Ballesteros y L. Álvarez Castro (N. 49-2604). II RCEH, 27 (2003), 584-586 (Suárez). - V. núm. 511260 .

\section{Gómez de Avellaneda, Gertrudis}

53-1281. Airbiv, María C. - Género, poesía y esfera pública. Gertrudis Gómez de Avellaneda y la tradición romántica. Trotta, Madrid, 2002. 330 pp. II RLit, 65 (2003), 308-310 (Ferrús).

53-1282. Ralch, Karex L. - "The quid pro quo of Gómez de Avellaneda's $\mathrm{El}$ millonario y la maleta". - RNo, 44 (2003), 155-161.

53-1283. Selmov, Ainxtider R. - "Tradición y subversión en la prosa de Gertrudis Gómez de Avellaneda". RNo, 42 (2001), 107-114. 
Gutiérrez Nájera, Manuel

53-1284. Rossiello, LEONARdo - "Analogía y sensibilidad en los cuentos de Manuel Gutiérrez Nájera”. - LMM, 14 (2003), 75-91.

\section{Heredia, José María de}

53-1285. Altenberg, T. - Melancolia en la poesía de José María Heredia (N. 502477). If NRFH, 52 (2004), 219-223 (Lara Astorga); Ibero, 2003, núm. 9, 254-256 (Pagni).

\section{Herrera y Reissig, Julio}

53-1286. Castillo, Jorge Luis - "Los éxtasis de mi villorrio: Herrera y Reissig, Luis Carlos López y la subversión de los idilios de aldea". - $B I C C$, 53 (1998), 582-594.

\section{Holmberg, Eduardo Ladislao}

53-1287. Cortés Rocca, PaOla - "El misterio de la cuarta costilla. Higienismo y criminología en el policial médico de Eduardo Holmberg". - Ibero, 2003, núm. 10, 67-78.

\section{Hoyos y Vinent, Antonio de}

53-1288. Alfonso García, M. del C. Antonio de Hoyos y Vinent, una figura del decadentismo hispánico (N. 491064). II RCEH, 26 (2002), 575-578 (Schulman).

\section{Inclán, Luis $G$.}

53-1289. Sol, Maneel - "Luis Inclán ante la crítica”. - TC, 2003, núm. 12, 117-127.

53-1290. Sol, Manuel - "Refranes, adagios, sentencias y locuciones en Astucia de Luis Inclán". - RLitPop, 2003, núm. 1, 52-63.
Marti, José

53-1291. Ballón AgutrRe, Josế - Martí y Blaine en la dialéctica de la Guerra del Pacifico (1879-1883). — UNAM, México, 2003. 449 pp. (Serie Nuestra Améri$\mathrm{ca}, 59)$.

53-1292. Rodríguez-Luis, J. - Re-reading José Martí (1853-1895): One hundred years later (N. 50-2484). II RCEH, 27 (2003), 383-384 (Ellis). - V. núm. 51-1278.

53-1293. Rotker, S. - The American chronicles of José Martí: Journalism and modernity in Spanish America, trs. J. French \& K. Semler (N. 51-2797). II TC, 2002, núm. 1,, 290-294 (Mora Brauchli).

\section{Matto de Tumer, Clorinda}

53-1294. Berg, MarX G. - - "Role models and Andean identities in Clorinda Matto de Turner's Hilma-Sumac". Studies in honor of Denah Lida, eds. M. G. Berg \& Lanin A. Gyurko (Potomac, Maryland, 2005), pp. 297-305.

\section{Méndez de Cuenca, Laura}

53-1295. Mora, Pablo - "Cartas de Laura Méndez de Cuenca a Enrique de Olavarría y Ferrari: dos promotores de la cultura mexicana". - LMM, 14 (2003), 241-287.

53-1296. Stochnialek, Hanna - "Laura Méndez de Cuenca: la mejor cuentista mexicana del siglo XIx". - TC, 2002, núm. 11, 215-228.

\section{Mesonero Romanos, Ramón}

53-1297. Ferraz Martínez, Antonio "Entre novela y teatro: el discurso de Mesonero Romanos sobre los artículos de costumbres en el marco de la transformación moderna del concepto de imitación". - RLit, 65 (2003), 85-117.

V. también núm. 1564 . 
Ochoa y Acuña, A. M. de

53-1298. Martínez Luna, Esther "Anastasio de Ochoa y Acuña, un aliado de Lizardi: una polémica en el Diario de México". — LMM, 14 (2003), 225-240.

\section{Pardo Bazán, Emilia}

53-1299. LARSEN, KeVIn S. - “«Seguía los adelantos de la termodinámica». Las imágenes termodinámicas en Los pazos de Clloa y La madre naturaleza". BICC, 53 (1998), 294-313.

\section{Payno, Manuel}

53-1300. Chaves, José Ricardo - "Payno criptofantántisco. Intermitencias mágicas en El fistol del diablo". - LMM, 14 (2003), 63-74.

53-1301. García de la Sienra, Rodrigo "El cronotopo del autor en Los bandidos de Rio Frio". - LMM, 14 (2003), 63-86.

\section{Pérez Galdós, Benito}

53-1302. Pérez Galdós, B. - Miau, ed. F. Díez de Revenga (N. 50-1194). II RCEH, 27 (2003), 391-393 (Cano Ballesta). - V. núm. 51-2809.

53-1303. Fernández Ciflentes, Llis "La de Bringas: metrópoli, moda, identidad". - Studies in honor of Denah Lida, eds. M. G. Berg \& Lanin A. Gyurko (Potomac, Maryland, 2005), pp. 163-177.

53-1304. Gabriele, Johx P. - "The hungry protagonist and narrative famine: $\mathrm{Vi}$ llaamil as anthropofagus in Galdós's Miau". - RVo, 42 (2001), 65-72.

53-1305. López, Sitrita - "The occult in Galdós's El caballero encantado". RNo, 42 (2001), 115-125.

53-1306. Mandrell, James - "The three faces of Misericordia". - Studies in honor of Denah Lida, eds. M. G. Berg \& Lanin A. Gyurko (Potomac, Maryland, 2005), pp. 178-186.
53-1307. Schnepf, Michael A. - "The return of the artist: A note on the sketches from the gallery proofs of Pérez Galdós's $L a$ de los tristes destinos (1907)". - RNo, 44 (2003), 133-142.

\section{Salaverría, José María}

53-1308. Sánchez Garcia, Raquel - "José María Salaverría y la profesionalización del escritor". - RLit, 65 (2003), 145-165.

\section{Sarmiento, Domingo Faustino}

V. núm. 1388.

\section{Silva, José Asunción}

53-1309. LaRaway, David - "Shadowing Silva". - RCEH, 26 (2002), 537-544. 53-1310. VALCÁRCEL, EVA - "De sobremesa de José Asunción Silva. Pintura, poesía y novela". - BICC, 53 (1998), 60-78.

\section{Valera, Juan}

53-1311. VAlERA, JUAN - Correspondencia. T. 2: (Años 1862-1875). Ed. de Leonardo Romero Tobar, María Ángeles Ezama Gil y Enrique Serrano Asenjo. - Castalia, Madrid, 2003. 633 pp. (Nueva Biblioteca de Erudición Crítica, 22).

53-1312. VAleRA, JUAN - Correspondencia. T. 3: (Años 1876-1883). Dir. de Leonardo Romero Tobar; ed. de María Ángeles Ezama Gil y Enrique Serrano Asenjo. - Castalia, Madrid, 2004. 639 pp. (Nueva Biblioteca de Erudición y Crítica, 22).

\section{Vega Armentero, Remigio}

53-1313. VeGA Armentero, Remiglo ¿Loco o delincuente? Novela social contemporánea (1890). Ed. de Pura Fernández; texto fijado por J. P. Gabino. - Celeste Ediciones, Madrid, 2001. 
292 pp. II RLit, 64 (2002), 299-301

(Bonilla Cerezo).

\section{Zorrilla, José}

53-1314. Zorrilla, J. - Leyendas, ed. S. García Castañeda (N. 51-1316). II RCEH, 26 (2002), 581-583 (Iarocci).

\section{SIGLO XX}

\section{Albalucía, Ángel}

53-1315. Contreras, Álvaro - "La subjetividad como relato". - TC, 2002, núm. 10, 35-53.

\section{Alberti, Rafael}

53-1316. HaVARD, ROBERT - The crucified mind. Rafael Alberti and the surrealist ethos in Spain. - Tamesis, London, 2001. 251 pp. II Ibero, 2003, núm. 11, 257-260 (Albert).

\section{Aleixandre, Vicente}

53-1317. García Diaz, M. Ángeles - Una aspiración a la luz. La poesía de Vicente Aleixandre. - Reichenberger-Universidad de Oviedo, Kassel-Oviedo, 2001. 265 pp. II Ibero, 2003, núm. 11, 256-257 (López-Casanova).

53-1318. PaO, María T. - "Eatermark: Reading Aleixandre's "El mar no de una hoja de papel»". - RNo, 44 (2003), 183-191.

\section{Allende, Isabel}

53-1319. Lutes, L. Y. - Allende, Buitrago, Luiselli: aproximaciones teóricas al concepto del "Bildungsroman" femenino (N. 52-2833). II Carav, 2003, núm. 81, 356-359 (Abdala Mesa).

V. también núm. 1533.
Álvarez Piñer, Luis

53-1320. Álvarez Piñer, Luis y Gerardo Drego - Cartas (1927-1984). Ed. de Juan Manuel Díaz de Guereñu. Pre-Textos, Valencia, 2001. 315 pp. II EHF, 26 (2004), 383-386 (Díez de Revenga).

\section{Antillano, Laura}

53-1321. González Stephan, Beatriz "Escritura de memorias subalternas". - TC, 2002, núm. 10, 21-34.

53-1322. Zambrano, Gregory - "Narrar desde la memoria. La historia posible (Laura Antillano, Ana Teresa Torres y Milagros Mata Gil)”. - TC, 2002, núm. 10, 243-253.

\section{Antolín, Enriqueta}

V. núm. 767.

Ares, Alonso

53-1323. Balcelis, José María - "Memoria de las raíces en la poética de Alonso Ares". - EHF, 26 (2004), 237-245.

\section{Arguedas, José María}

53-1324. Archibald, Priscillla - "Overcoming science in the Andes". RCEH, 27 (2003), 407-434.

53-1325. Sales Salvador, Dora - Puentes sobre el mundo. Cultura, traducción y forma literaria en las narrativas de transculturación de José Maria Arguedas y Vikram Chandra. - P. Lang, BernBerlin-New York-Wien, 2004. 677 pp. 53-1326. SCHWAlB, CaRios - La narrativa totalizadora de José Maria Arguedas, Julio Ramón Ribeyro y Mario Vargas Llosa. - P. Lang, New York, 2001. 143 pp. II Ibero, 2003, núm. 9, 259-261 (Bellini). 
Aridjis, Homero

53-1327. Grurko, Lavin A. - "Presecution and deliverance in Aridjis' 1492: Vida y tiempos de Juan Cabezón de Castilla". - Studies in honor of Denah Lida, eds. M. G. Berg \& Lanin A. Gyurko (Potomac, Maryland, 2005), pp. 351-365.

\section{Arlt, Roberto}

53-1328. Corral, Rose - "Rescate del relato "Un ladrón» de Roberto Arlt". - Carav, 2002, núm. 79, 245-256. 53-1329. Godinas, Laurette - "La secreta sociedad: Arlt, Borges, Piglia". $S L L, 5$ (2003), núm. 1, 53-71.

53-1330. Valko, JenNifer M. - "Roberto Arlt's Aguafuertes patagónicas". - Bríjula, 3 (2004), núm. 1, 28-34.

\section{Arreola, Juan José}

53-1331. Martínez, José Llis - "Recuento de Juan José Arreola". — LMM, 13 (2002), 169-184.

53-1332. MATA, ÓScaR - "Los Presentes, del maestro editor Juan José Arreola". - LMM, 13 (2002), 187-214.

\section{Asturias, Miguel Ángel}

V. núms. 1478, 1533.

$A u b, \operatorname{Max}$

53-1333. Aчв, Max - Hablo como hombre. Ed., introd. y notas de Gonzalo Sobejano. - Fundación Max Aub, Segorbe, 2002. 289 pp. II Ibero, 2003, núm. 10, 209-210 (Ehrlicher).

53-1334. ALB, Max - Heine. Ed., introd. y notas de Mercedes Figueras; trad. del alemán de Berit Balzer. - Fundación Max Aub, Segorbe, 2000. 254 pp. II Ibero, 2003, núm. 10, 210-211 (Ehrlicher).

53-1335. Au B, M. - Obras completas: T. 2: El laberinto mágico I, ed. crítica, est. in- trod., y notas de I. Soldevila Durante y J. Antonio Pérez Bowie (N. 492698). II RCEH, 27 (2003), 362-364 (del Pino).

53-1336. Aznar Soler, Mantel - "Autocensura y censura de las literaturas del exilio republicano en la España franquista: sobre la edición de 1966 de Mis páginas mejores, de Max Aub". - Ins, 2003, núm. 678, 2-5.

53-1337. Aznar Soler, Maveel - "Cara y cruz de Max Aub o el drama del intelectual en los laberintos de la política española". - Max Aub: de la farsa a la tragedia. Actas de las Jornadas de estudio (Verona, 13-14 de junio de 2003) (Verona, 2004), pp. 119-138.

53-1338. Basalisco, Jullo - "De alguín tiempo a esta parte. primera pieza aubiana del ciclo judio". - Max Aub: de la farsa a la tragedia. Actas de las Jornadas de estudio (Verona, 13-14 de junio de 2003) (Verona, 2004), pp. 83-96. 53-1339. Buschmann, Albrecht - "Max Aub: Campo de los almendros (1968/1981)". - Romane in Spanien. T. 1: 1975-2000, eds. T. Bodenmüller, T. M. Scheerer \& A. Schönberger (Frankfurt/M., 2004), pp. 47-59. 53-1340. Cancellier, Avtonella - "Botánica y palegénesis en Fábula verde". - Max Aub: de la farsa a la tragedia. Actas de las Jornadas de estudio (Verona, 13-14 de junio de 2003) (Verona, 2004), pp. 241-250.

53-1341. Caddet, Francisco - "La revista Sala de Espera: una tragedia en tres actos". - Max Aub: de la farsa a la tragedia. Actas de las Jomadas de estudio (Verona, 13-14 de junio de 2003) (Verona, 2004), pp. 179-193.

53-1342. Caldfet, Francisco - "Valencia en Campo de los almendros". - Ins, 2003, núm. 678, 6-8.

53-1343. Dlago, Nel - "Max Aub y el teatro que no fue o la imprudencia de ejercer la crítica teatral". - Max Aub: de la farsa a la tragedia. Actas de las Jomadas de estudio (Verona, 13-14 de junio de 2003) (Verona, 2004), pp. $153-178$.

53-1344. DoméNech, Ricardo - "De algún tiempo a esta parte el comienzo". Ins, 2003, núm. 678, 9-11. 
53-1345. Faber, SebastiaAn - "El exilio mexicano de Max Aub: la relación con el régimen anfitrión". - RCEH, 26 (2002), 423-438.

53-1346. Faber, Sebastiaan - "Escribir a chorro suelto: el miedo a borrar y otras obsesiones exílicas". - Ins, 2003, núm. 678, 11-14.

53-1347. Grillo, Rosa María - "Entre la farsa y la tragedia, en compañía de un cuervo y un árbol". — Max Aub: de la farsa a la tragedia. Actas de las Jormadas de estudio (Verona, 13-14 de junio de 2003) (Verona, 2004), pp. 227-239.

53-1348. Llorens Marzo, Luis - "Res do mestica, res publica. La vida conyugal de Max Aub". - Max Aub: de la farsa a la tragedia. Actas de las Jornadas de estudio (Verona, 13-14 de junio de 2003) (Verona, 2004), pp. 97-118.

53-1349. LloRENTE, ANA - "Tradición y modernidad en la representación de El cerco de Max Aub". - Max Aub: de la farsa a la tragedia. Actas de las Jornadas de estudio (Verona, 13-14 de junio de 2003) (Verona, 2004), pp. 139-152.

53-1350. Lluch Prats, Javier - "De algún tiempo a esta parte. la tragedia europea en clave de monólogo". - Max Aub: de la farsa a la tragedia. Actas de las Jornadas de estudio (Verona, 13-14 de junio de 2003) (Verona, 2004), pp. 59-81.

53-1351. LONDERO, ElEANOR - "La mimesis incierta del cuervo escritor". Íns, 2003, núm. 678, 14-17.

53-1352. López García, José Ramón "Un tiempo de muros, los Diarios israelíes de Max Aub". - Íns, 2003, núm. 678, 17-20.

53-1353. Monti, Silvia - "Max Aub dramaturgo: de la farsa a la tragedia (¿a la farsa?)". - Max Aub: de la farsa a la tragedia. Actas de las Jornadas de estudio (Verona, 13-14 de junio de 2003), ed. S. Monti (Verona, 2004), pp. 7-16.

53-1354. Monti, Silvia (ed.) - Max Aub: de la farsa a la tragedia. Actas de las Jornadas de estudio (Verona, 13-14 de junio de 2003). - Edizioni Fiorini-Università degli Studi di Verona, Verona, 2004. 262 pp.

53-1355. Naharro-Calderón, José María - "Claves vigentes de El rapto de Euro- pa". - Max Aub: de la farsa a la tragedia. Actas de las Jornadas de estudio (Verona, 13-14 de junio de 2003) (Verona, 2004), pp. 35-58.

53-1356. Naharro-Calderón, José María - "Los papeles mojados de Max Aub”. - Ins, 2003, núm. 678, 21-22. 53-1357. Pérez Bowie, José Antonio "El canon narrativo aubiano". - Íns, 2003, núm. 678, 22-27.

53-1358. Pérez Bowie, José Antonio "Presupuestos de la teoría teatral de Max Aub. Una aproximación". Max Aub: de la farsa a la tragedia. Actas de las Jornadas de estudio (Verona, 13-14 de junio de 2003) (Verona, 2004), pp. 195-219.

53-1359. RoDriguez, JUAN - "Juego de cartas como hipertexto". - Ins, 2003, núm. 678, 27-30.

53-1360. Sanavio, Piero - "¿Dónde está España?". - Max Aub: de la farsa a la tragedia. Actas de las Jornadas de estudio (Verona, 13-14 de junio de 2003) (Verona, 2004), pp. 251-255.

53-1361. Soldevila Durante, Ignacio "Anotaciones a una carta de Aub acerca de su teatro". - Max Aub: de la farsa a la tragedia. Actas de las Jornadas de estudio (Verona, 13-14 de junio de 2003) (Verona, 2004), pp. 221-225.

53-1362. Trambaioli, Marcella - "El desconfiado prodigioso y Jácara del avaro de Max Aub: estilización del teatro clásico y magisterio de ValleInclán". - Max Aub: de la farsa a la tragedia. Actas de las Jornadas de estudio (Verona, 13-14 de junio de 2003) (Verona, 2004), pp. 17-33.

\section{Azuela, Mariano}

53-1363. Gutiérrez Cham, Gerardo "Periferias de silencio, culpa y transgresión en Los de abajo y Al filo del agua". - LMM, 14 (2003), 113-137.

53-1364. Leal, LUIS (sel.) - Mariano Azuela; el hombre, el médico, el novelista. - CONACULTA, México, 2001. II LMM, 13 (2002), 277-279 (López Mena). 
Barral, Carlos

V. núm. 767.

Beltrán, Rosa

V. núm. 1593.

\section{Benedetti, Mario}

53-1365. Faccini, Carmen - Mario Benedetti: un discurso contrahegemónico en el exilio. - Hispamérica, Gaithesburg, Maryland, 2001. 128 pp. II TC, 2002, núm. 11, 303-305 (Cortés Sol).

\section{Bergamín, José}

53-1366. Ambrosi, P. (ed.) - José Bergamin. Tra avanguardia e barocco (N. 52 1169). II RLit, 65 (2003), 675-678 (González).

\section{Bioy Casares, Adolfo}

53-1367. Avellaneda, Andrés — "Bioy mirando al sudeste". - Homenaje a Adolfo Bioy Casares. Una restrospectiva de su obra, eds. A. de Toro y S. Regazzoni (Frankfurt/M.-Madrid, 2002), pp. 269-284.

53-1368. Block de BEHAR, LISA - "Nuevas versiones de un pacto fáustico". - Homenaje a Adolfo Bioy Casares. Una restrospectiva de su obra, eds. A. de Toro y S. Regazzoni (Frankfurt/M.-Madrid, 2002), pp. 23-39.

53-1369. CÉdola, Estela y Jerónimo LeDESMA - "Del crimen a la guerra. Sobre las adaptaciones cinematográficas que hizo Torre Nilsson de «El perjurio de la nieve» (1947) y Diario de la guerra del cerdo (1969) de Adolfo Bioy Casares". - Homenaje a Adolfo Bioy Casares. Una restrospectiva de su obra, eds. A. de Toro y S. Regazzoni (Frankfurt/M.-Madrid, 2002), pp. 293-315

53-1370. Domínguez, María Luisa "Adolfo Bioy Casares: la construcción imaginaria del cuerpo". - Homenaje a Adolfo Bioy Casares. Una restrospectiva de su obra, eds. A. de Toro y S. Regazzoni (Frankfurt/M.-Madrid, 2002), pp. 171-189.

53-1371. Grieco y Bavío, Alfredo y MiGUEL VEDDA - "Nueva refutación del coraje. La destrucción del "mito criollo" en la obra de Adolfo Bioy Casares". - Homenaje a Adolfo Bioy Casares. Una restrospectiva de su obra, eds. A. de Toro y S. Regazzoni (Frankfurt/M.-Madrid, 2002), pp. 251-267. 53-1372. Höfner, ECKARD - "Utopisme et médialité dans La invención de Morel de Adolfo Bioy Casares (1940)". Homenaje a Adolfo Bioy Casares. Una restrospectiva de su obra, eds. A. de Toro y S. Regazzoni (Frankfurt/M.-Madrid, 2002), pp. 87-109.

53-1373. Jordan, Mery Erdal - "El enmascaramiento genérico de $E l$ sueño de los héroes de Adolfo Bioy Casares". - Homenaje a Adolfo Bioy Casares. Una restrospectiva de su obra, eds. A. de Toro y S. Regazzoni (Frankfurt/M.-Madrid, 2002), pp. 123-134.

53-1374. Kian-Harald, Karimi - "Creado, pero no según la imagen de Dios. Metamorfosis de la inmortalidad en la obra de Bioy Casares". - Homenaje a Adolfo Bioy Casares. Una restrospectiva de su obra, eds. A. de Toro y S. Regazzoni (Frankfurt/M.-Madrid, 2002), pp. $67-85$.

53-1375. Loustaunau Braidot, Fernando - "Historias vividas: Adolfo Bioy Casares y Susana Soca". - Homenaje a Adolfo Bioy Casares. Una restrospectiva de su obra, eds. A. de Toro y S. Regazzoni (Frankfurt/M.-Madrid, 2002), pp. 329-339.

53-1376. Mazzei, Norma - "Lengua urbana, registro y notas humorísticas de Bioy". - Homenaje a Adolfo Bioy Casares. Una restrospectiva de su obra, eds. A. de Toro y S. Regazzoni (Frankfurt/M.-Madrid, 2002), pp. 229-236.

53-1377. Navascuês, Javier de - "Los Buenos Aires de Bioy Casares: parodia y fantasía". - Homenaje a Adolfo Bioy Casares. Una restrospectiva de su obra, eds. A. de Toro y S. Regazzoni 
(Frankfurt/M.-Madrid, 2002), pp. 197-213.

53-1378. Regazzoni, Susana - "El doble en la obra de Adolfo Bioy Casares". - Homenaje a Adolfo Bioy Casares. Una restrospectiva de su obra, eds. A. de Toro y S. Regazzoni (Frankfurt/M., 2002), pp. 157-170.

53-1379. RINCÓN, CARLOS - "La relación texto-imagen: las ilustraciones de Norah Borges para la Invención de Morel". - Homenaje a Adolfo Bioy Casares. Una restrospectiva de su obra, eds. A. de Toro y S. Regazzoni (Frankfurt/M.Madrid, 2002), pp. 317-327.

53-1380. RosA, Nicolás - "Máquina y maquinismo en La invención de Morel". - Homenaje a Adolfo Bioy Casares. Una restrospectiva de su obra, eds. A. de Toro y S. Regazzoni (Frankfurt/M.Madrid, 2002), pp. 41-63.

53-1381. Santiago Pellegrino, Carlos "Secretos de memoria: las visitaciones a la ciudad de Buenos Aires en la narrativa de Adolfo Bioy Casares”. Homenaje a Adolfo Bioy Casares. Una restrospectiva de su obra, eds. A. de Toro y S. Regazzoni (Frankfurt/M.-Madrid, 2002), pp. 191-196.

53-1382. Speranza, Graciela - "La voz del otro: Bioy Casares y Silvina Ocampo". - Homenaje a Adolfo Bioy Casares. Una restrospectiva de su obra, eds. A. de Toro y S. Regazzoni (Frankfurt/M.-Madrid, 2002), pp. 285-292.

53-1383. Toro, Alfonso de - "Breves reflexiones sobre el concepto de lo fantástico de Bioy Casares en $L a$ invención de Morel y Plan de evasión. Hacia la literatura medieval-virtual". - Homenaje a Adolfo Bioy Casares. Una restrospectiva de su obra, eds. A. de Toro y S. Regazzoni (Frankfurt/M.-Madrid, 2002), pp. 135-155.

53-1384. Toro, Aifonso de y Susana RegazzONI (eds.) - Homenaje a Adolfo Bioy Casares. Una retrospectiva de su obra. Literatura, ensayo, filosofía, teoria de la cultura, crítica literaria. - Vervuert-Iberoamericana, Frankfurt/M.-Madrid, 2002. 352 pp. (Teoria y Crítica de la Cultura Literaria, 23). II $R F, 115$ (2003), 420-422 (García Simón).
53-1385. UlloA, Noemí - "La trama de la ciudad". - Homenaje a Adolfo Bioy Casares. Una restrospectiva de su obra, eds. A. de Toro y S. Regazzoni (Frankfurt/M.-Madrid, 2002), pp. 215-227.

53-1386. Zubieta, Ana María - "El lujo, lo popular y el humor: sinuosidades de un camino". - Homenaje a Adolfo Bioy Casares. Una restrospectiva de su obra, eds. A. de Toro y S. Regazzoni (Frankfurt/M.-Madrid, 2002), pp. 237-250.

V. también núms. 1387, 1397.

\section{Borges, Jorge Luis}

53-1387. Borges, Jorge LuIs y Adolfo Bioy Casares - Museo. textos inéditos. Ed. de Sara Luisa del Carril y Mercedes Rubio de Zocchi. - Emecé, Buenos Aires, 2002. II NRFH, 52 (2004), 223-227 (Cajero).

53-1388. Abraham Hall, Nancy - "Saving the Gutres: Borges, Sarmiento and Mark". - RCEH, 26 (2002), 527-536.

53-1389. Barrenechea, Ana María "Borges y su invención de Buenos Aires". - Studies in honor of Denah Lida, eds. M. G. Berg \& Lanin A. Gyurko (Potomac, Maryland, 2005), pp. 321-324.

53-1390. Bergero, A. J. - Haciendo camino: pactos de la escritura en la obra de Jorge Luis Borges (N. 52-2875). II RCEH, 27 (2003), 364-366 (Scarto).

53-1391. DUbNick, Heather L. - “Mirrors and fatherhood: Doubling, mise en abîme, and the uncanny in the fictions of Jorge Luis Borges". - $R N o$, 44 (2003), 69-81.

53-1392. Echavarria, Arturo - "The Americas and (in) Europe: Borges and the literary tradition". - Studies in honor of Denah Lida, eds. M. G. Berg \& Lanin A. Gyurko (Potomac, Maryland, 2005), pp. 325-338.

53-1393. FINE, R. - La desautomatización en literatura. $S u$ ejemplificación en " $E l$ Aleph" de Jorge Luis Borges (N. $52-$ 2882). II TC, 2002, núm. 10, 287-289 (Cruz Mendoza). 
53-1394. Flores, Arturo C. - "Entre tangos y compadritos: Borges y «El hombre de la esquina rosada"”. AION-R, 45 (2003), 463-474.

53-1395. González, José Mandel - "Génesis del motivo épico en la poesía de Jorge Luis Borges: de la apoteosis a la claudicación". - TC, 2002, núm. 11, 111-117.

53-1396. Jensen, Julio - "Jorge Luis Borges, ¿moderno o posmoderno? Análisis del trasfondo vanguardista de la escritura borgesiana". - RRo, 36 (2001), 81-96.

53-1397. McAdam, Alfred - "Borges y Bioy: La invención de Morel". - Homenaje a Adolfo Bioy Casares. Una restrospectiva de su obra, eds. A. de Toro y S. Regazzoni (Frankfurt/M.-Madrid, 2002), pp. 111-121.

53-1398. Nieto, Haydée IsABel - "Identidad, discriminación y destino: los inmigrantes de Borges". - SignosU, 2003, núm. 39, 203-214.

53-1399. Olea Franco, R. (ed.) - Borges: desesperaciones aparentes y consuelos secretos (N. 48-1255). If RCEH, 26 (2002), 549-551 (Prieto). - V. núm. 51-1367.

53-1400. Ruffinelli, Jorge - "Leer a Borges ver cine”. - TC, 2002, núm. $11,43-52$.

53-1401. Zorrilla, A. M. - La voz sentenciosa de Borges (N. 51-2914). II SignosU, 2003, núm. 39, 259-260 (Martínez). V. también núms. 607, 611, 1329, 1532.

\section{Boullosa, Carmen}

53-1402. García-Serrano, María Victoria - "«Sí, mejor desaparece» de Carmen Boullosa: ¿una versión de "la loca criolla en el ático»?". - $T C, 2002$, núm. 10, 145-157.

53-1403. Ortega, Julio - "La identidad literaria de Carmen Boullosa". - $T C$, 2002, núm. 10, 139-144.

53-1404. Ulioa, Justo C. - "Redes textuales: los epigrafes en Duerme de Carmen Boullosa". - RNo, 44 (2003), 103-111
Bravo, Roberto

53-1405. Cortés, Jaime Erasto - "Si tú mueres primero de Roberto Bravo". $T C, 2002$, núm. 10, 277-280.

\section{Bryce Echenique, Alfredo}

53-1406. Kraklisin, Margarita - "Mentira romántica y verdad novelesca: mito y estructura en La amigdalitis de Tarzán de Alfredo Bryce Echenique". - RNo, 42 (2002), 359-369.

\section{Buero Vallejo, Antonio}

53-1407. Brakel, Arthur - "Ciegos or invidentes? Antonio Buero Vallejo's En la ardiente oscuridad: Motif, paradox, and contradiction". - RNo, 43 (2002), 99-106.

V. también núm. 1472.

\section{Buitrago, Fanny}

V. núm. 1319.

\section{Cansinos Assens, Rafael}

53-1408. García, Carlos - "Correspondencia entre Rafael Cansinos Assens y Guillermo de Torre (1916-1955): anticipo". - Íns, 2003, núm. 683, 4-6.

\section{Capetillo, Luisa}

53-1409. Guzzo, Cristina - "Luisa Capetillo y Salvadora Medina Onrubia de Botana: dos íconos anarquistas. Una comparación”. - Alpha, 2004, núm. 20, 165-180.

\section{Carpentier, Alejo}

53-1410. Gordon, Richard A. - "The disalignment of Bernini's columns: Historiographic variations in El arpa y la sombra". — RNo, 44 (2003), 173-181. 
53-1411. Teulière, GÉrard - 'D'un réelmerveilleux anamorphique: le décor mythique de l'histoire chez Alejo Carpentier". - Carav, 2003, núm. 81, 163-186.

V. también núm. 1533.

\section{Carrere, Emilio}

53-1412. Labrador Ben, Julia M. - "Génesis y autoría de La torre de los siete jorobados de Emilio Carrere". - RLit, 64 (2002), 475-503.

\section{Casona, Alejandro}

53-1413. Feito, José Manuel - "El peregrino de la barba florida. Leyenda milagrosa, de Alejandro Casona". - BIEA, 57 (2003), 71-111.

\section{Castellanos, Rosario}

53-1414. BUNDGÅRD, ANA — "Interdiscursividad y cultura popular en El eterno femenino de Rosario Castellanos". $T C, 2002$, núm. 10, 7-19.

\section{Castellet, José María}

53-1415. Bonet, Laureano - "Premio Boscán 1953: un texto olvidado de Josep Maria Castellet”. - Íns, 2003, núm. 684, 23-27.

53-1416. Navas OCaña, Isabel - "Castellet, los novísimos y las vanguardias". - EHF, 26 (2004), 307-318.

\section{Castro, Américo}

53-1417. Carrasco Urgorti, María Soledad - "Américo Castro (1885-1972)". FGL, 2003, núms. 33/34, 291-293.

\section{Cepeda Samudio, Álvaro}

53-1418. Gilard, JaCQues - "Un texto maltratado de Cepeda Samudio". -
Carav, 2003, núm. 81, 293-297.

V. también núm. 1533.

\section{Cermuda, Luis}

53-1419. Cruz Mendoza, Yólotl - "Luis Cernuda y la búsqueda del paraíso". - $T C, 2002$, núm. 11, 273-280.

53-1420. Insausti Herrero-Velarde, GaBRIEL - La presencia del romanticismo inglés en el pensamiento poético de Luis Cernuda. - EUNSA, Navarra, 2000. 256 pp. II RLit, 64 (2002), 656-659 (Pardellas Velay).

53-1421. Neira, Julio y Javier Pérez Bazo Luis Cernuda en el exilio. Lecturas de "Las nubes" y "Desolación de la quimera". Presses Universitaires du Mirail, Toulouse, 2002. 314 pp. II RLit, 65 (2003), 330-334 (Díez de Revenga).

53-1422. Rodríguez Ponce, María Isabel - "Elementos de cohesión textual en Ocnos y Variaciones sobre tema mexicano, de Luis Cernuda". - AEF, 26 (2003), 369-386.

53-1423. Serrano de la Torre, José MiGUEL - "Sobre estética y poética cernudianas. Unas notas desde la lectura de Pierre Reverdy". - RLit, 65 (2003), 167-197.

53-1424. Srcot, Bernard - "Aproximaciones al peritexto de La realidad y el deseo: «À mon seul Désir»". - NRFH, 52 (2004), 77-105.

53-1425. Villena, Luis Antonio de $-R e$ beldia, clasicismo y crisis. (Luis Cermuda. Asedios plurales a un poeta principe). Pre-Textos, Valencia, 2002. 142 pp. II Ibero, 2003, núm. 9, 239-240 (Pardellas Velay).

53-1426. Zubiaur, I. - - La construcción de la experiencia en la poesia de Luis Cermuda (N. 52-2933). II RLit, 65 (2003), 673-675 (Llera).

\section{Chacel, Rosa}

53-1427. Dolgin Casado, Stacey - "Desintegración de los componentes narrativos en Estación. Ida y vuelta, de Rosa Chacel". - RNo, 44 (2003), 13-20. 
Chirbes, Rafael

53-1428. WITT, SABINE - "Rafael Chirbes: La caída de Madrid (2000)". — Romane in Spanien. T. 1: 1975-2000, eds. T. Bodenmüller, T. M. Scheerer \& A. Schönberger (Frankfurt/M., 2004), pp. 307-314.

\section{Clavel, Ana}

53-1429. Quintana, Isabel Alicia - "Ficciones oculares y topográficas: Los deseos y su sombra de Ana Clavel". $S L L, 5$ (2003), núm. 1, 97-112.

\section{Cortázar, Julio}

53-1430. Báez Rivera, Emilio R. - "Inversión e invención de imágenes y espejos: el "poeticismo» romántico de Julio Cortázar en su narrativa breve a la luz de Imagen de John Keats". Alpha, 2004, núm. 20, 29-51.

53-1431. Lalrentis, Avtonella de - "Il potere della parola. Los reyes. rilettura dell'opera di Julio Cortázar tra mito e realtà". - AION-R, 45 (2003), 517-527.

\section{Crespo, Ángel}

53-1432. Ardanuy, Jordi - "Hacia la epifanía de la sombra”. - Íns, 2002, núm. 670, วั-9.

53-1433. Chiappini, Gaetano - "Variaciones sobre la sombra". - Ins, 2002, núm. 670, 10-12.

53-1434. Corredor-Matheos, José - "El viaje en la poesía de Ángel Crespo". - Ins, 2002, núm. 670, 9-10.

53-1435. Dolfi, Latra - "Ángel Crespo: vida y poesía. (Sobre el epistolario inédito con Oreste Macrí)". - Ins, 2002, núm. 670, 12-15.

53-1436. Guménez-Frontín, José Luis "Los trabajos y los días de Ángel Crespo". — Ins, 2002, núm. 670, 15-16.

53-1437. Gomez Bedate, Pilar - "Para situar la obra de Ángel Crespo". - Ins, 2002, núm. 670, 2-4.

53-1438. Krantetz, Alejandro - "Paisa- jes de la palabra, los diarios de Ángel Crespo". - Ins, 2002, núm. 670, 1718, 23-24.

53-1439. Payeras, María - "La voz de la creación”. - Ins, 2002, núm. 670, 24-26.

53-1440. Pont, Jaume - "Ángel Crespo en el postismo: claves poéticas". Ins, 2002, núm. 670, 27-29.

53-1441. Pujol Russeli, Sara - "Ángel Crespo, hacia una poética integradora”. - Íns, 2002, núm. 670, 29-33. 53-1442. Ruiz Casanova, José Francisco - "Amadis y el explorador: los diálogos poéticos de Ángel Crespo". - Íns, 2002, núm. 670, 33-35.

53-1443. Sánchez Robayna, Andrés "Docena florentina: espacio, construcción, memoria”. - Ins, 2002, núm. 670, 35-36.

53-1444. Terry, ArTHur - "La idea del lenguaje en la poesía tardía de Ángel Crespo". - Íns, 2002, núm. 670, 37-40.

\section{Cuesta, Jorge}

53-1445. MÉNARD, BÉATRICE - "Las figuras del deseo en los sonetos de Jorge Cuesta”. - Alpha, 2004, núm. 20, 69-89. 53-1446. Ramírez, IsRaEL - "Jorge Cuesta: persona real y persona figurada. Algunas consideraciones biográficas”. - LMM, 14 (2003), 115-146.

\section{Délano, Poli}

53-1447. Кiм, Euisux - "El hombre frente al espejo: identidad y militancia en Este lugar sagrado". - RNo, 42 (2002), 197-204.

\section{Delibes, Miguel}

53-1448. Schönberger, AXer - "Miguel Delibes: El hereje (1998)". - Romane in Spanien. T. 1: 1975-2000, eds. T. Bodenmüller, T. M. Scheerer \& Axel Schönberger (Frankfurt/M., 2004), pp. 263-285.

53-1449. Stalder, Thomas - "Miguel Delibes: El disputado voto del señor Cayo 
(1978)". - Romane in Spanien. T. 1: 1975-2000, eds. T. Bodenmüller, T. M. Scheerer \& A. Schönberger (Frankfurt/M., 2004), pp. 9-27.

\section{Deniz, Gerardo}

53-1450. Sicot, BERNARd - "Trois poètes hispano-mexicains”. - Carav, 2002, núm. 78, 211-252.

\section{Diego, Gerardo}

V. núm. 1320.

\section{Domecq, Brianda}

V. núm. 628.

\section{Donoso, José}

53-1451. Bados Ciria, Concepción "Conjeturas sobre la memoria de mi tribu de José Donoso: testamento personal y literario". - $T C, 2002$, núm. 11, 247-260.

53-1452. Fernández, Margarita - "El mundo de José Donoso en Este domingo". - BICC, 53 (1998), 616-628.

53-1453. Lusky Friedman, Mary - "José Donoso's "Taratura»: The uses of cultural patrimony". - RNo, 44 (2004), 327-335.

\section{Eltit, Diamela}

53-1454. Niebylski, Dianna C. - "Hacia una estética de la carencia: estrategias formales de resistencia en Diamela Eltit". - Studies in honor of Denah Lida, eds. M. G. Berg \& Lanin A. Gyurko (Potomac, Maryland, 2005), pp. 366-381.

\section{Espinosa, Germán}

53-1455. Forquero Quintero, Gustavo - "El concepto de tiempo en La teje- dora de coronas. Una astronómica desmitificación del tiempo histórico". BICC, 53 (1998), 355-368.

\section{Esquivel, Laura}

53-1456. NeHru, MEesha - "A future mexican national identity? Laura Esquivel's La ley del amor". - AEla, 38 (2004), 217-232.

53-1457. Schaefer, Claudia - “¿Panteón o paraíso? Visiones milenarias de la ciudad de México en La ley del amor de Laura Esquivel". - TC, 2002, núm. 10, 107-118.

\section{Fernández, Macedonio}

53-1458. González Martínez, Henry "El minicuento en la narrativa de Macedonio Fernández". - BICC, 53 (1998), 605-616.

53-1459. Prieto, J. - Desencuadernados: vanguardias ex-céntricas en el Río de la Plata. Macedonio Fernández y Felisberto Hernández (N. 52-1275). II RCEH, 27 (2003), 600-602 (Camblong).

Fernández Santos, Jesús

53-1460. Santos, José Diego - Léxico y sociedad en "Los Bravos" de Jesús Fernández Santos. - Universidad, Alicante, 2001. 165 pp. II EHF, 26 (2004), 364 365 (Garnelo Merayo).

\section{Ferré, Rosario}

53-1461. Montes Garcés, Elizabeth "Subjetividad e ideología en Maldito amor de Rosario Ferré". - TC, 2002, núm. 10, 131-138.

\section{Ferretis, Jorge}

53-1462. Franco Bagnouls, Lourdes "Un cuento recuperado de Jorge Ferretis". - LMM, 13 (2002), 231-242. 


\section{Fuentes, Carlos}

53-1463. Estrada, Oswaldo - "La constancia narrativa de Carlos Fuentes en sus novelas para vírgenes". - RCEH, 27 (2003), 241-252.

53-1464. Tremblay, Emmanuelle - "Les avatares de la Chronique et la circularité des récits dans Terra nostra". RCEH, 27 (2003), 533-559.

\section{Gala, Antonio}

53-1465. Yague Ferrer, María Isabel "El tema de los escondidos de la posguerra española en la producción teatral de Antonio Gala y Juan José Alonso Millán". - RLit, 64 (2002), 505-521.

V. también núm. 1468.

\section{García Lorca, Federico}

53-1466. Aguilar Álvarez-BAy, Tatiana "Edición crítica de «Poema doble del Lago Edem» de Federico García Lorca". - NRFH, 52 (2004), 45-77.

53-1467. Arango, Manuel Antonio - Simbolo y simbología en la obra deFederico García Lorca. - Espiral Hispano Americana, Madrid, 1999. 479 pp. II BICC, 54 (1999), 331-332 (Vergara Silva).

53-1468. EgEA-FernándeZ-Montesinos, Alberto - García Lorca, Blas Infante y Antonio Gala. Un nacionalismo alternativo en la literatura andaluza. - Fundación Blas Infante, Sevilla, 2001. 284 pp. II RFilR, 20 (2003), 307-310 (Martin-Márquez).

53-1469. FINARDI L. E. - I santi di Federico. Agiografia romano-andalusa di García Lorca (N. 52-1289). II RLit, 64 (2002), 307-308 (Sanmartín Bastida).

53-1470. Forino, SimONA - "L'América Latina in Lorca e Lorca in América Latina". - AION-R, 45 (2003), 529-543.

53-1471. Hernández, Mario - "Federico García Lorca, hispanista". - FGL, 2003, núms. 33/34, 335-355.

53-1472. Herzog, Christophe - "Catarsis y público en El público (1935), Gui- llermo Tell tiene los ojos tristes (1955) y El concierto de San Ovidio (1962)". BHH, 2004, núm. 3, 45-72.

53-1473. Maurer, Christopher - "Carta desde Boston: novohispanismos". FGL, 2003, núms. 33/34, 149-156.

53-1474. Prellwitz, Norbert von - "Observaciones sobre la "Baladilla de los tres ríos» de Federico García Lorca". - Criticón, 2003, núms. 87/88/89, 689-696.

53-1475. Puig Mares, María del Pilar "¡Oh negro toro de pena!". - RFLL, 22 (2004), 273-297.

53-1476. Román RomÁn, IsABel - "Los mitos clásicos en la poesía de Federico García Lorca". - AFF, 26 (2003), 387-405.

Garcia Márquez, Gabriel

53-1477. Barón Thaidigsmann, Jaime "Aproximación al problema de la casualidad y los personajes en Del amory otros demonios". - $\mathrm{BHH}, 2004$, núm. 4, 5-26.

53-1478. Camacho Delgado, José Manuel — “Verdugos», «delfones»y «favoritos» en la novela de la dictadura”. Carav, 2003, núm. 81, 203-228.

53-1479. Gilard, Jacques - "Otro texto costeño de García Márquez: el mismo pero distinto". - Carav, 2002, núm. 79, 257-264.

53-1480. Jamieson, Martín - "García Márquez al teléfono: “'haber?»”. RNo, 42 (2002), 177-178.

53-1481. KERR, R. A. - "As I lay dying: Archetropic imagery in García Márquez's El general en su laberinto". $R N o, 44$ (2004), 267-273.

53-1482. Nava Estrada, Verónica GabrieLA - “"Apártense vacas que la vida es corta». La visión carnavalesca en Cien años de soledad". - SLL, 5 (2003), núm. 1, 73-96.

53-1483. Urdapilleta Muñoz, Marco "El pathos trágico de El general en su laberinto. Entre la historia y la expresión”. - AEla, 38 (2004), 117-143.

V. también núm. 1533. 


\section{Garcia Ponce, Juan}

53-1484. Pereira, Armando - "El juego de escrituras en De Anima". - LMM, 14 (2003), 147-160.

\section{Garro, Elena}

53-1485. WINKI.ER, J. A. - Light into shadow. Marginality and alienation in the work of Elena Garro (N. 52-2992). II Ibero, 2003, núm. 11, 270-272 (Beucker).

\section{Gerchunoff, Alberto}

53-1486. BleTZ, MAYE. - "Agrarian utopia in Alberto Gerchunoff's Los gauchos". - Brújula, 3 (2004), núm. 1, 35-52.

53-1487. Szurmuk, Mónica - "Identidades en tránsito: la «Autobiografía» de Alberto Gerchunoff". - Brújula, 3 (2004), núm. 1, 11-24.

\section{Girri, Alberto}

53-1488. Villanueva, Alberto - "Alberto Girri, una poética de la interioridad objetiva". - I, 2003, núm. 57, 114-132.

\section{Gómez Carrillo, Enrique}

53-1489. Kronik, JoHn W. - "Enrique Gómez Carrillo a la defensa de Clarín". - RLit, 65 (2003), 239-256.

\section{Gómez de la Serna, Ramón}

53-1490. Cabañas Alamán, R. - Fetichismo y perversión en la novela de Ramón Gómez de la Serna, pról. R. Cardona (N. 52-3001). II RCEH, 27 (2003), 367368 (Valis).

53-1491. Hodde, J. H. - El contraste en la obra de Ramón Gómez de la Serna (N. 48-1410). II Ibero, 2003, núm. 11, 254 255 (Ehrlicher). - V. núm. 51-1446.

53-1492. Navarro Dominguez, Eloy "Javier Gómez de la Serna en los ini- cios literarios de Ramón”. - Íns, 2003, núm. 682, 8, 17-19.

\section{Gopegui, Belén}

53-1493. Pichler, Georg - "Belén Gopegui: La conquista del aire (1998)". Romane in Spanien. T. 1: 1975-2000, eds. T. Bodenmüller, T. M. Scheerer \& Axel Schönberger (Frankfurt/M., 2004), pp. 231-246.

\section{Gorostiza, José}

53-1494. Cantú, A. - En la red de cristal. Edición y estudio de "Muerte sin fin", de José Gorostiza (N. 48-3110). II LMM, 14 (2003), 236-240 (Rodríguez Zuleta).

\section{Goytisolo, Juan}

53-1495. Bussiere-Perrin, A. - La thêâtre de l'expiration. Regards sur l'oeuvre de rupture de Juan Goytisolo (N. 49-2892). II Ibero, 2003, núm. 12, 229-231 (Alary).

53-1496. Ehrlicher, HaNNo - "Im land des zweifels. Juan Goytisolos Beitrag zu einer Kultur der Migration". $R F, 115$ (2003), 210-230.

53-1497. Llored, YANNicK - "Poétique et conception du sens dans l'oeuvre de Juan Goytisolo". - RRo, 39 (2004), 257-277.

\section{Goytisolo, Luis}

53-1498. Carney, Terry - "Sex, the body, and human subjectivity in Luis Goytisolo's erotic novel Escalera hacia el cielo". - RNo, 42 (2002), 131-137.

V. también núm. 767.

\section{Grande, Félix}

53-1499. Garnelo Merayo, Saúl "Aproximación a la trayectoria poética de Félix Grande". - EHF, 26 (2004), 265-274. 


\section{Grandes, Almudena}

53-1500. Balletta, Felice - "Almudena Grandes: Las edades de Lulú (1989)". - Romane in Spanien. T. 1: 19752000 , eds. T. Bodenmüller, T. M. Scheerer \& A. Schönberger (Frankfurt/M., 2004), pp. 115-126.

53-1501. Belmonte Serrano, José - “Te llamaré Viernes: un análisis de la incomunicación y la soledad". - AION-R, 45 (2003), 475-489.

V. también núm. 768 .

\section{Guerra Garrido, Raúl}

53-1502. Martínez Fernández, José EnriQUE - "La escritura autobiográfica y palimpséstica de Cuaderno secreto, de Raúl Guerra Garrido". - EHF, 26 (2004), 187-201.

\section{Guillén, Jorge}

53-1503. Martín Ezpeleta, Antonio "La historia literaria en la correspondencia Guillén-Salinas". - Historia literaria/Historia de la literatura, ed. L. Romero Tobar (Zaragoza, 2004), pp. 285-302.

\section{Guillén, Nicolás}

53-1504. GILARD, Jacques - "El poeta y el paisaje. Primera versión de un poema de Nicolás Guillén". - Carav, 2003, núm. 80, 245-248.

\section{Hernández, Felisberto}

V. núm. 1459.

\section{Hernández, Miguel}

53-1505. Hernández, M. - El rayo que no cesa, ed. J. M. Balcells (N. 52-3008). II Rlit, 65 (2003), 328-330 (Luján).
Hinojosa, Rolando

53-1506. López-Valero Colbert, Olga "La pícara Viola: sexualidad y marginalidad en Estampas del Valle y otras obras, de Rolando Hinojosa". - RNo, 44 (2004), 309-316.

\section{Holguín, Andrés}

53-1507. Arango, Daniel - "Andrés Holguín en el recuerdo". - BICC, 53 (1998), 642-646.

\section{Huidobro, Vicente}

53-1508. Hopfe, K. - Vicente Huidobro, der Creacionismo und das Problem der Mimesis (N. 46-1235). II RF, 115 (2003), 127-129 (Ophey). - V. núm. 51-1454.

\section{Jacobs, Bárbara}

53-1509. Llarena, Alicia - " "Uno mismo es un mundo viajable»: hacia el mapa narrativo de Bárbara Jacobs". - TC, 2002, núm. 10, 203-213.

\section{Jaramillo Agudelo, Darío}

53-1510. Pitol, Sergio - "Presencia de Darío Jaramillo". - TC, 2003, núm. $12,73-84$.

\section{Jarnés, Benjamín}

53-1511. Jarnés, Benjamín - Teotía del zumbel. Introd., ed. y notas de Armando Pego Puigbó. - Institución "Fernando el Católico"-Excma. Diputación de Zaragoza, Zaragoza, 2000. 211 pp. II RLit, 64 (2002), 297-299 (Bonilla Cerezo).

53-1512. Domínguez LasierRa, JUaN - "El regreso del profesor inútil". - Íns, 2003, núm. 673, 29-32.

53-1513. Fernández Utrera, María Sole$\mathrm{DAD}$ - "Tántalo: Jarnés y la renova- 
ción teatral de la vanguardia". - Ins, 2003, núm. 673, 22-234.

53-1514. GRACIA, JORDI - "Fuera de foco: la prosa de ideas de Jarnés". - Íns, 2003, núm. 673, 12-13.

53-1515. Herrero SenÉs, JUAN - "Al arte por la vida: Jarnés y Nietzsche". Íns, 2003, núm. 673, 27-29.

53-1516. Lanz, Juan José - "Fragmento, perspectiva y conocimiento en Locura y muerte de nadie de Benjamín Jarnés". - Íns, 2003, núm. 673, 18-21.

53-1517. Nora, Eugenio G. DE - "El novelista ausente". - Íns, 2003, núm. 673, 3-4.

53-1518. Pego Puigbó, Armando - "Benjamín Jarnés ante sus fronteras críticas". - Íns, 2003, núm. 673, 9-12.

53-1519. Ródenas de Mova, Domingo "Benjamín Jarnés: la reluctancia al desvanecimiento". - Íns, 2003, núm. 673 , p. 3.

53-1520. Ródenas de Moya, Domingo "Recodos del itinerario jarnesiano: Cascabeles, Claraval y "Cien por cien»". - Íns, 2003, núm. 673, 5-8.

53-1521. Serrano Asenjo, EnriQue "Las otras vidas de Benjamín Jarnés". -Íns, 2003, núm. 673, 16-17.

53-1522. Soguero, Francisco M. - "La última lección de $E l$ profesor inútil: $E l$ aprendiz de brujo, una novela inédita de Benjamín Jarnés”. - Íns, 2003, núm. 673, 24-27.

\section{Jiménez, Juan Ramón}

53-1523. JIMÉnEZ, J. R. - La muerte, ed. D. Martínez Torrón (N. 51-3019). II RLit, 64 (2002), 296-297 (Reina). 53-1524. JIMÉNEZ, JUAN RAMÓN - La realidad invisible. Ed. de Diego Martínez Torrón. - Cátedra, Madrid, 2000. II RLit, 64 (2002), 296-297 (Reina). 53-1525. JimÉnEz, JuAN RAMóN - Unidad. Ed. de Diego Martínez Torrón. Seix Barral, Barcelona, 2000. II RLit, 64 (2002), 296-297 (Reina).

53-1526. Alarcón Sierra, Rafael - Juan Ramón fiménez. Pasión perfecta. - Espasa-Calpe, Madrid, 2003. 305 pp. II RLit, 65 (2003), 670-673 (Sanz Manzano).
53-1527. Geninasca, Jacques - " "Cielo" de Juan Ramón Jiménez". - Semiosis, 2001, núm. 7, 5-8.

53-1528. Sanz Manzano, M. Ángeles "De por qué Juan Ramón Jiménez renunció a ser novelista: el poeta y su teoría de la novela". - RLit, 65 (2003), 471-500.

53-1529. Zanetta, María A. - "La evolución del arquetipo femenino en la poesía y en la pintura de Juan Ramón Jiménez: un análisis comparado". Ins, 2003, núm. 682, 3-6.

\section{Krauze, Ethel}

53-1530. Cortina, Guadalupe - "Historias y mujeres: feminización de espacios culturales en la narrativa de Ethel Krauze”. - TC, 2002, núm. 10, 89-106.

\section{Lamborghini, Leónidas}

53-1531. Porrúa, ANa - Variaciones vanguardistas. La poética de Léonidas Lamborghini. - Beatriz Viterbo, Rosario, 2001. 254 pp. II Ibero, 2003, núm. 9, 261-263 (Dalmaroni).

\section{Lamborghini, Osvaldo}

53-1532. Astuttr, Adriana - Andares clancos. Fábulas del menor en Osvaldo Lamborghini, J. C. Onetti, Rubén Dario, J. L. Borges, Silvina Ocampo y Manuel Puig. - Beatriz Viterbo, Rosario, 2001. 245 pp. II Ibero, 2003, núm. 10, 231-232 (Zanin).

\section{Larreta, Enrique}

53-1533. Arango, Manuel Antonio - Literatura y conciencia social en nueve escritores representativos de Hispanoamérica: Enrique Larreta, Miguel Ángel Asturias, Juan Rulfo, Alejo Carpentier, Isabel Allende, Eduardo Caballero Calderón, Manuel Mejía Vallejo, Gabriel García Márquez y Álvaro Cepeda. - Pliegos, 
Madrid, 2003. 188 pp. II AEla, 38 (2004), 257-261 (Wouters).

\section{León, Maria Teresa}

53-1534. Bedla, Martha Marina - "Antón Perulero. Un cuento inédito de María Teresa León". - RLit, 64 (2002), 569-585.

\section{Lezama Lima, José}

53-1535. Lezama Lima, José - Antología de la poesía cubana. - Verbum, Madrid, 2002. II Carav, 2002, núm. 81, 338-343 (Benabdelouahed).

53-1536. Lezama Lima, J. - Cartas a Eloísa y otra correspondencia (N. 49-1301). II Carav, 2002, núm. 79, 308-312 (Benabdelouahed).

53-1537. LezAMA Lima, José - La posibilidad infinita. Archivo de José Lezama Lima. - Verbum, Madrid, 2000. 309 pp. II Carav, 2002, núm. 79, 307-308 (Benabdelouahed).

53-1538. Martínez de Olcoz, Nieves "Poéticas de Paradiso: la reescritura de un mito de vanguardia". $-T C$, 2002, núm. 11, 95-109.

53-1539. Pérez-Amador Adam, Alberto "La escala interrumpida. Las cartas del tarot como símbolos y estructura narrativa de Oppiano Licario de José Lezama Lima”. - I, 2003, núm. 57, 133-156.

V. también núm. 615 .

\section{Llamazares, Julio}

53-1540. Kunz, Marco - "Julio Llamazares: La lluvia amarilla (1988)". - Romane in Spanien. T. 1: 1975-2000, eds. T. Bodenmüller, T. M. Scheerer \& A. Schönberger (Frankfurt/M., 2004), pp. 103-113.

\section{López, Luis Carlos}

V. núm. 1286.
López Velarde, Ramón

53-1541. Fernández, Ángel José - "López Velarde, Pegaso y su nostalgia por la provincia". - LMM, 14 (2003), 93-113.

\section{Loynaz, Dulce Maria}

53-1542. Horno Delgado, Aslnción Margen acuático: poesía de Dulce Maria Loynaz. - Júcar, Madrid, 1998. 203 pp. II RCEH, 26 (2002) , 562-563 (Sibbald).

\section{Machado, Antonio}

53-1543. Iravedra Valea, Araceli - El poeta rescatado. Antonio Machado y la poesia del "grupo de «Escorial"”. - Biblioteca Nueva, Madrid, 2001. 252 pp. II RLit, 64 (2002), 308-311 (Alarcón Sierra); RLit, 65 (2003), 666-670 (Pardellas Velay).

53-1544. ISSOREL, JACQUES - Collioure 1939. Ultimos días de Antonio Machado. (Con una selección de poemas escritos en homenaje a Antonio Machado exiliado). - Éditions Mare Nostrum, Perpignan, 2002. 84 pp. II RLit, 65 (2003), 664-666 (Balcells).

53-1545. Lanz, Juan José - "Cien años de Soledades, de Antonio Machado". - Ins, 2003, núm. 683, 2-3.

53-1546. López Castro, Armando - "La vivencia del tiempo en Antonio Machado". - EHF, 26 (2004), 287-299.

53-1547. López Martínez, María ISABeL "El género de los Proverbios y cantares de Antonio Machado". - $A E F, 26$ (2003), 189-202.

53-1548. Mattauch, Hans - "Las "galerías" de Antonio Machado: origen y evolución de una metáfora central de su poesía". - RLit, 65 (2003), 225-235.

53-1549. Olivio Jiménez, José y Carlos Javier Morales - Antonio Machado en la poesía española. La evolución interna de la poesía española 1939-2000. - Cátedra, Madrid, 2002. 329 pp. II Ibero, 2003, núm. 10, 207-209 (Pardellas Velay). 
53-1550. RuSSELl, ROBERT - "La generación de Machado y Unamuno". Studies in honor of Denah Lida, eds. M. G. Berg \& Lanin A. Gyurko (Potomac, Maryland, 2005), pp. 210-216.

V. también núm. 1568.

\section{Machado, Manuel}

53-1551. Machado, Manuei - Impresiones. El modernismo (articulos, crónicas y reseñas, 1899-1909). Ed. de Rafael Alarcón Sierra. - Pre-Textos-Diputación de Sevilla, Valencia, 2000. 498 pp. II RLit, 64 (2002), 647-653 (Chicharro).

53-1552. Alarcón Sierra, R. - Entre el modernismo y la modernidad: la poesía de Manuel Machado ("Alma" y "Caprichos”) (N. 50-2852). II RCEH, 26 (2002), 545-546 (Badenes). - V. núm. 52-3032.

\section{Mañás, José Ángel}

53-1553. Mollnero, Nina L. - "The «real» story of drugs, Dasein and José Ángel Mañás's Historias del Kronen". - RCEH, 27 (2003), 291-306.

\section{Marechal, Leopoldo}

53-1554. Cheadle, N. - The ironic apocalypse in the novels of Leopoldo Marechal (N. 48-3158). II RCEH, 27 (2003), 568-569 (Deffis de Calvo). - V. núm. 52-3035.

\section{Marias, Javier}

53-1555. IngendaAy, PALL - "Javier Marías: El hombre sentimental (1986)". Romane in Spanien. T. 1: 1975-2000, eds. T. Bodenmüller, T. M. Scheerer \& A. Schönberger (Frankfurt/M., 2004), pp. 61-71.

53-1556. López de ABIADA, José MaNcel y ANGelIKA TheILe-Becker - "Javier Marías: Corazón tan blanco (1992)". - Romane in Spanien. T. 1: 1975-2000, eds.
T. Bodenmüller, T. M. Scheerer \& A. Schönberger (Frankfurt/M., 2004), pp. 151-171.

53-1557. Navarro Git, SANDra - "La voz del narrador en las novelas de Javier Marías". - RLit, 65 (2003), 199-210. 53-1558. Navarro GIL, Sandra - "Una aproximación al estilo literario de Javier Marías". - RFLL, 22 (2004), 187-193.

V. también núm. 768 .

\section{Marsé, Juan}

53-1559. Fernávdez, Álvaro - "Un canto en la tiniebla. Miradas, voces y memoria en la poética de Juan Marsé". - Ibero, 2003, núm. 11, 65-87.

\section{Martin Gaite, Carmen}

53-1560. Bergenson, Craig N. - "Time in El cuarto de atrás". - RNo, 43 (2003), 137-145.

53-1561. Jlrado Morales, José - La trayectoria narrativa de Carmen Martín Gaite (1925-2000). - Gredos, Madrid, 2003. 543 pp. II RLit, 65 (2003), 679-681 (Herrera Campos).

53-1562. TAYlor, Karen L. - "La visión contradictoria de la postguerra española de Carmen Martín Gaite”. Studies in honor of Denah Lida, eds. M. G. Berg \& Lanin A. Gyurko (Potomac, Maryland, 2005), pp. 250-257.

53-1563. UechManN, Natascha - "Carmen Martín Gaite: La reina de las nieves (1994)". - Romane in Spanien. T. 1: 1975-2000, eds. T. Bodenmüller, T. M. Scheerer \& A. Schönberger (Frankfurt/M., 2004), pp. 193-207.

\section{Martin Santos, Luis}

53-1564. Fernández, ENrique - " "La patrona de Huéspedes» de Mesonero Romanos, inspiración de Tiempo de si lencio". - RNo, 44 (2003), 219-224.

V. también núm. 612. 
Martinez, Tomás Eloy

53-1565. Villanueva Benavides, Idalia "Eva Perón o la construcción de una identidad: un análisis de Santa Evita de Tomás Eloy Martínez". - TC, 2002, núm. 11, 7-23.

\section{Martínez Mediero, Manuel}

53-1566. Garrielle, John P. - "Fowl deeds: Anthropophagy and the politics of eating in Manuel Martínez Mediero's El último gallinero". - RNo, 44 (2003), 211-218.

\section{Martinez Ruiz, José (Azorin)}

53-1567. Azorín - La bolita de marfil. Ed. de Dolores Thion Soriano-Mollá. Biblioteca Nueva, Madrid, 2002. 238 pp. II RLit, 65 (2003), 659-661 (Lozano Marco).

53-1568. Blanco Aguinaga, Carlos "Crisis espiritual, crisis histórica: Azorín, Unamuno y Machado en la encrucijada de la modernidad". Studies in honor of Denah Lida, eds. M. G. Berg \& Lanin A. Gyurko (Potomac, Maryland, 2005), pp. 196-209.

53-1569. Escartín Gual, Montserrat - "El diario íntimo, Azorín y la nueva novela". - RLit, 64 (2002), 107-120.

53-1570. Jurkievich, G. - In pursuit of the natural sign. Azorin and the poetics of Ekphrasis (N. 50-1253). II RCEH, 26 (2002), 563-565 (Landeira). - V. núm. 51-1345.

\section{Martínez Sierra, Maria}

53-1571. Blanco, Alda - "Desde la pared de vidrio hasta la otra orilla: el exilio de María Martínez Sierra". Studies in honor of Denah Lida, eds. M. G. Berg \& Lanin A. Gyurko (Potomac, Maryland, 2005), pp. 236-249.
Mata Gil, Milagros

V. núms. 1321, 1322.

\section{Maturana, Andrea}

53-1572. MaIz-Peña, Magdalena - "Los apetitos de la ansiedad: cuerpo-texto de Andrea Maturana". - TC, 2002, núm. 10, 179-186.

53-1573. Mateo del Pino, Ángeles "Cuando lo que (des) une no es el amor sino el espanto. (El discurso de la modernidad en la narrativa chilena actual: Andrea Maturana)". - TC, 2002, núm. 10, 187-202.

\section{Matute, Ana Maria}

53-1574. QUiRK, RonALD J. - "The revealing eyes of Ana María Matute's characters in Historias de la Artámila". $R N o, 43$ (2002), 107-115.

\section{Melo, Juan Vicente}

53-1575. EsPINOSA, ERIC - "La obediencia nocturma o los hijos del caos". - TC, 2002, núm. 10, 273-276.

\section{Mejía Vallejo, Manuel}

V. núm. 1533.

\section{Moix, Terenci}

53-1576. Rosi Song, H. - "Behind the female stereotype: Terenci Moix and the tactics of subversive cultural representations". - RNo, 43 (2002), 13-22

\section{Monsiváis, Carlos}

53-1577. Egan, L. - Carlos Monsiváis. Culture and chronicle in contemporary Mexico (N. 52-1398), II RCEH, 27 (2003), 575-577 (Faber); Ibero, 2003, núm. 10, 228-229 (Winter). 
53-1578. Monsiváls, C. - Aires de familia: cultura y sociedad en América Latina (N. 51-1498). II RCEH, 27 (2003), 389391 (Egan). - V. núm. 52-1397.

\section{Montero, Rosa}

53-1579. Wilton, Jennifer - "Rosa Montero: Crónica del desamor (1979)". Romane in Spanien. T. 1: 1975-2000, eds. T. Bodenmüller, T. M. Scheerer \& A. Schönberger (Frankfurt/M., 2004), pp. 29-46.

V. también núm. 768.

\section{Monterroso, Augusto}

53-1580. Kıeveland, Anne Karine - "Vino viejo en odres nuevos. La oveja negra y demás fábulas, de Augusto Monterroso en el contexto de la nueva fábula". LMM, 14 (2003), 161-207.

53-1581. Rodriguez Hernández, Sixto "Augusto Monterroso: el eterno movimiento de la vida". - $T C, 2003$, núm. 12, 169-176.

\section{Moreno, Marvel}

53-1582. Moreno, Marvel - Cuentos completos. Ed. de Jacques Gilard y Fabio Rodríguez Amaya. - Grupo Editorial Norma, Bogotá, 2001. 442 pp. II Carav, 2002, núm. 79, 335-338 (Celis).

\section{Muñiz Huberman, Angelina}

53-1583. García Muñoz, Gerardo - " $\mathrm{El}$ mercader de Tudela: una doble perspectiva". - Semiosis, 2001, núm. 7, 10-19.

Muñoz Molina, Antonio

53-1584. IbáÑez EHrLich, M.-T. (ed.) Los presentes pasados de Antonio Muñoz Molina (N. 50-2881). II Ibero, 2003, núm. 9, 240-242 (Buschmann). - V. núm. 51-3087.
53-1585. Scheerer, Thomas - "Antonio Muñoz Molina: Beatus Ille (1986)”. Romane in Spanien. T. 1: 1975-2000, eds. T. Bodenmüller, T. M. Scheerer \& A. Schönberger (Frankfurt/M., 2004), pp. 73-88.

V. también núm. 767.

\section{Neruda, Pablo}

53-1586. Neruda, Pablo - Ode al vino e altre odi elementari. A cura di Giovanni Battista de Cesare. - Passigli Editori, Firenze, 2002. II AION-R, 45 (2003), 598-601 (Volpe).

53-1587. Bellini, G. - Viaje al corazón de Neruda (N. 52-3061). If Carav, 2002, núm. 79, 299-300 (Pailler).

53-1588. Karageorgot-Bastea, Christina - "El legado de los cantores: historia y poesía de América en el Canto general". - SLL, 5 (2003), núm. 1, 11-29.

53-1589. Poupeney-Hart, Catherine y Monique Sarfati-Arnald (eds.) $-\mathrm{Pa}$ blo Neruda. Mitos y personaje. - Girol, Ottawa, 1998. 159 pp. II RCEH, 26 (2002), 571-573 (Aldarondo).

53-1590. Sánchez, Fervando Fabio "Segunda Residencia, una crítica a la materialidad". - Semiosis, 2001, núm. 7,3445 .

\section{Nervo, Amado}

53-1591. Jiménez Aguirre, Gustavo "Tres cuentos no recogidos de Amado Nervo". - LMM, 14 (2003), 199-213. 53-1592. MonsiváIs, Carlos - Yo te bendigo, vida. Amado Nervo: crónica de vida y obra. - Gobierno del Estado de Nayarit, México, 2002. II LMM, 14 (2003), 228-232 (Lara Astorga).

\section{Nizri, Vicki}

53-1593. González Mateos, Adriana "Otra vez Eva y Lilith. La reescritura de los mitos de género por tres escritoras mexicanas: Vicky Nizri, Rosa Beltrán y Cristina Rivera Garza”. SLL, 5 (2003), núm. 1, 239-249. 
Ocampo, Silvina

V. núms. 1382, 1532.

\section{Onetti, Juan Carlos}

53-1594. Ainsa, Fernando - "Del yo al nosotros: el desdoblamiento de la identidad en la obra de Juan Carlos Onetti". - Alpha, 2004, núm. 20, 11-27.

53-1595. Antúnez Olivera, Rocío "Onetti: periodismo y literatura". SLL, 5 (2003), núm. 1, 113-127.

V. también núm. 1532.

\section{Otero, Blas de}

53-1596. Ayuso, José Paulino - "Ángel fieramente humano: entre raíz mortal, fronda de anhelo". - Ins, 2003, núms. 676/677, 5-8.

53-1597. Bai.cellos, José María - "Blas de Otero en las antologías poéticas de posguerra". - Ins, 2003, núms. $676 / 677,5457$.

53-1598. Cruz, Sabina de la - " DDesamor»: un poema olvidado”. - Ins, 2003, núms. 676/677, 3-5.

53-1599. Debicki, Andrew P. - "Creación artística y realidad humana: la poesía intertextual de Mientras". - Íns, 2003, núms. 676/677, 51-53.

53-1600. Ferrari, Martha Beatriz - “"El juego más peligroso": Historias fingidas y verdaderas, de Blas de Otero". Ins, 2003, núms. 676/677, 47-48.

53-1601. IGLeSLA, ÁNGel DE LA - "La poesía de Blas de Otero (conceptos formales)". - Íns, 2003, núms. $676 / 677,14-15$.

53-1602. IgLesia, JAVIER DE LA - "Blas de Otero y Ángel de la Iglesia: el grupo de Champa". - Ins, 2003, núms. 676/677, 11-14.

53-1603. Lanz, Juan José - "Blas de Otero: nuevas lecturas críticas". - Ins, 2003 , núms. 676/677, 2-3.

53-1604. Lanz, JuAN José - "La ciudad de memoria: imaginario urbano y lucha de clases en la obra de Blas de Otero". - Ins, 2003, núms. 676/677, 23-24, 37-40.
53-1605. Le Bigot, Claude - "Configuración de la voz social en la poesía de Blas de Otero". - Ins, 2003, núms. 676/677, 16-20.

53-1606. Martín Hernández, Evelune "Ancia: hombre acantilado, desacantilado". - Íns, 2003, núms. 676/677, 9-11. 53-1607. Miró, EMILIo - "Que trata de España: la noche y el alba”. - Ins, 2003, núms. 676/677, 42-46.

53-1608. Montejo Gurruchaga, Lucia "La relación de Blas de Otero con Ínsula. Una colaboración estrecha $\mathrm{y}$ continua". - Íns, 2003, núms. $676 / 677,58-60$.

53-1609. Scarano, Laura - "Blas de Otero: una poética de "La página rota»". - Ins, 2003, núms. 676/677, 20-23. 53-1610. Sobejano, Gonzalo - "Blas de Otero y el poema en prosa: "Las nubes», "Vivir para ver»”. - Ins, 2003, núms. 676/677, 49-51.

53-1611. Torre, Esteban - "Desde Andalucía: un soneto inédito de Blas de Otero y Carlos Álvarez". - Íns, 2003, núms. 676/677, 53-54.

53-1612. Yubero Ferrero, Fernando "Algunas notas sobre cosmovisión simbólica e impulso lírico en Pido la paz y la palabra, de Blas de Otero". Íns, 2003, núms. 676/677, 40-412.

\section{Pacheco, José Emilio}

53-1613. Macedo Rodríguez, Alfonso "La metaficción como recurso de los fantástico en "La fiesta brava», de José Emilio Pacheco". - SLL, 5 (2003), núm. 1, 227-237.

\section{Parra, Eduardo Antonio}

53-1614. Palaversich, Diana - "Espacios y contra-espacios en la narrativa de Eduardo Antonio Para". - TC, 2002, núm. 11, 53-74.

\section{Paso, Fernando del}

53-1615. Bendayán Ponte, Lilian - "José Trigo: un paso hacia la postmodernidad". — TC, 2003, núm. 12, 17-30. 
53-1616. Corral PeÑa, Elizabeth - "El primer capítulo de Linda 67. Historia de un crimen". - TC, 2003, núm. 12, 7-16.

53-1617. Corral Peña, Elizabeth - "Retratos en Noticias del Imperio". - Ibero, 2003, núm. 12, 53-68.

\section{Patán, Federico}

V. núm. 1450.

\section{Pavlosky, Eduardo}

53-1618. Scipioni, Esteia Patricia - Torturadores, apropiadores y asesinos. El terrorismo de estado en la obra dramática de Eduardo Pavlovsky. - Reichenberger, Kassel, 2000. 363 pp. II Ibero, 2003, núm. 10, 235-237 (Kiewert).

\section{Paz, Octavio}

53-1619. Sefamí, Jacobo - "Desde las grietas de la infancia: un fragmento de Pasado en claro, de Octavio Paz". LMM, 14 (2003), 139-160.

53-1620. Stanton, A. - Las primeras voces del poeta Octavio Paz (1931-1938) (N. 52-3081). II LMM, 14 (2003), 241-245 (Ortiz Flores); NRFH, 52 (2004), 227-229 (Verani).

V. tambiên núm. 574.

\section{Pellicer, Carlos}

53-1621. Escalante, Evodio - "Una obra maestra «desconocida» de Carlos Pellicer. Los sonetos de Hora de junio". — LMM, 13 (2002), 129-148.

\section{Pereira, Antonio}

53-1622. González Boixo, José Carlos (ed.) - Antonio Pereira. Recuento de invenciones. - Cátedra, Madrid, 2004. 378 pp. II EHF, 26 (2004), 377-380 (Álvarez Méndez).

\section{Pérez de Ayala, Ramón}

53-1623. Matas, Julio - “La revolución sentimental, de Ramón Pérez de Ayala, y la corriente del teatro de "fantasía" en el primer cuarto del siglo xx". Studies in honor of Denah Lida, eds. M. G. Berg \& Lanin A. Gyurko (Potomac, Maryland, 2005), pp. 187-195.

\section{Peri Rossi, Cristina}

53-1624. Dominglez, Carmen - "Las mujeres en La nave de los locos de Cristina Peri Rossi: viajeras en perpetua huida". - TC, 2002, núm. 10 , 159-167.

\section{Piglia, Ricardo}

53-1625. Corbatta, J. - Narrativas de la Guerra Sucia en Argentina (Piglia, Saer, Valenzuela, Puig) (N. 50-2914). II $R C E H, 27$ (2003), 370-372 (Deffis de Calvo). - V. núm. 52-3088.

53-1626. Demaria, L. - Argentina-s. Ricardo Piglia dialoga con la generación del 37 en la discontinuidad (N. 51-3113). II RCEH, 26 (2002), 555-557 (Legrás). -V. núm. 52-3089.

V. también núm. 1329.

\section{Pitol, Sergio}

53-1627. García Díaz, Teresa - "Sergio Pitol: viajes y moradas". - TC, 2003, núm. 12, 31-36.

\section{Pizarmik, Alejandra}

53-1628. Marín, Paola - "Lenguaje y representación en Árbol de Diana". $R N o, 42$ (2002), 341-348.

\section{Pombo, Álvaro}

53-1629. Altmann, Werner - "Álvaro Pombo: Los delitos insignificantes (1986)". - Romane in Spanien. T. 1: 
1975-2000, eds. T. Bodenmüller, T. M. Scheerer \& A. Schönberger (Frankfurt/M., 2004), pp. 89-102.

\section{Poniatowska, Elena}

53-1630. Martínez, María InÉS - "Lenguaje oral y marginalidad en Hasta no verte Jesús mío". - TC, 2003, núm. 12, $37-53$.

V. también núm. 628.

\section{Posse, Abel}

53-1631. Waldemer, Thomas P. - "The great chain of being: Ecocriticism in Abel Posse's Daimon". — RNo, 44 (2003), 51-59.

\section{Prada Oropeza, Renato}

53-1632. Prada Oropeza, Renato - El discurso-testimonio y otros ensayos. UNAM, México, 2001. 218 pp. II TC, 2002, núm. 11, 288-290 (Zúñiga).

53-1633. Prada Oropeza, Renato - "Hacia una fenomenología del discurso estético". - Semiosis, 2001, núm. 7, 74-86.

\section{Prados, Emilio}

53-1634. ChicA, F. - El poeta lector. La biblioteca de Emilio Prados (N. 49-3005). II RCEH, 27 (2003), 570-571 (López). - V. núm. 50-2922.

\section{Puga, María Luisa}

V. núm. 1625.

\section{Puig, Manuel}

53-1635. Giordano, Alberto - Manuel Puig. La conversación infinita. - Beatriz Viterbo, Rosario, 2001. 256 pp. II Ibero, 2003, núm. 10, 233-235 (López de Abiada).
53-1636. LogIE, ILSE - La omnipresencia de la mimesis en la obra de Manuel Puig: análisis de cuatro novelas. - Rodopi, Amsterdam-New York, 2001. 403 pp. II NRFH, 52 (2004), 229-231 (Fabry); Ibero, 2003, núm. 10, 232-235 (López de Abiada).

53-1637. Rosenkrantz, Guillermina $-E l$ cuerpo indómito. Espacios del exilio en la literatura de Manuel Puig. - Simurg, Buenos Aires, 1999. 171 pp. II Ibero, 2003, núm. 10, 232-235 (López de Abiada).

V. también núm. 1532.

\section{Quiroga, Horacio}

53-1638. Willey, Benjamíx - "La selva quijotesca: un análisis de la obra de Horacio Quiroga". - TC, 2002, núm. 11, 147-168.

\section{Rama, Ángel}

53-1639. Antelo, Rá́l - "Rama y la modernidad secuestrada". - EUSB, 2003-04, núms. 22/23, 17-36.

53-1640. Brotherston, Gordon - "Ángel Rama, intérprete de la literatura de América". - EUSB, 2003-04, núms. 22/23, 137-148.

53-1641. Giordano, Alberto - "Unos días en la vida de Ángel Rama”. EUSB, 2003-04, núms. 22/23, 163186.

53-1642. KleiN, Eva - "Aspectos de un malestar: Ángel Rama y su Diario". EUSB, 2003-04, núms. 22/23, 187 208.

53-1643. Lasarte Valcárcei., Javier "Rama transculturado". - EUSB, 2003-04, núms. 22/23, 149-162.

53-1644. Lecuna, Vicente - "La Caracas letrada: a partir del Diario de Ángel Rama". - EUSB, 2003-04, núms. 22/23, 209-230.

53-1645. Montaldo, Graciela - "Ángel Rama y los íconos de la cultura de la letra”. - EUSB, 2003-04, núms. 22/23, 67-80.

53-1646. Pacheco, Carlos y Marisela Guevara Sánchez - "Ángel Rama, la 
cultura venezolana y el epiśtolario de la Biblioteca Ayacucho". - EUSB, 200304, núms. 22/23, 99-136.

53-1647. Poblete, Juan - "El diario de Ángel Rama: el exilio intelectual y el intelectual en exilio". - EUSB, 2003 04, núms. 22/23, 247-268.

53-1648. Porras, María del Carmen - "Actualidad de una mirada crítica: el Diario 1974-1983 de Ángel Rama “. EUSB, 2003-04, núms. 22/23, 231-246.

53-1649. Rosa, RICHARD - "Acuñaciones: Ángel Rama y las economías de la letra". - EUSB, 2003-04, núms. 22/23, 37-66.

53-1650. Torres, MaríA InÉs dE - "Mapa sin tierra: Ángel Rama o la vocación crítica". - EUSB, 2003-04, núms. 22/23, 81-97.

53-1651. Trigo, Abril - "Apuntes para una crítica de la economía política en la globalización". - EUSB, 200304, núms. 22/23, 269-302.

\section{Ramírez, Sergio}

53-1652. Polit-Dueñas, Gabriela - "When the politicians construct fatherwor(l)ds Sergio Ramírez's Adiós muchachos". - RNo, 44 (2003), 163-172.

\section{Rebolledo, Efrén}

V. núm. 1683.

\section{Revueltas, José}

53-1653. Hurtado Hernández, Gerardo — "El enemigo" y "Centinela»: dos cuentos de José Revueltas en el archivo Juan de la Cabada". - LMM, 13 (2002), 243-251.

53-1654. Mateo, José Mavuel - "Conocimiento y transformación: Los dias terrenales de José Revueltas”. - LMM, 13 (2002), 149-167.

\section{Reyes, Alfonso}

53-1655. Reyes, Alfonso - La experiencia de la lectura. Ed. y pról. de Alicia Reyes. - Fundación para las Letras Mexicanas-Scripta-Ediciones a la Carta, México, 2004. 322 pp.

53-1656. Houvenaghel, Eugenia - "Alfonso Reyes frente al espisodio histórico de la Independencia: una actitud contradictoria". - RNo, 42 (2002), 265-272.

53-1657. Houvenaghel, Eugenia - "La fuerza persuasiva de Los dos caminos". - TC, 2002, núm. 11, 75-93.

53-1658. Holvenaghel, Eugenia - "Viejas polémicas sobre el Nuevo Mundo. Alfonso Reyes: historiografía y argumentación". - Carav, 2002, núm. 78, 127-142.

53-1659. TEJA, AdA MARÍA - "Ifigenia cruel de Alfonso Reyes, el poder femenino de romper el círculo de la violencia". — Semiosis, 2001, núm. 7, 104137.

\section{Ribeyro, Julio Ramón}

53-1660. García Muñoz, Gerardo - "El sonido de la agonía". - TC, 2002, núm. 11, 119-127.

V. también núm. 1326.

\section{Riera, Carmen}

53-1661. CAMí-VELA, MARÍA - La búsqueda de la identidad en la obra literaria de Carmen Riera. - Pliegos, Madrid, 2000. 176 pp. II Ibero, 2003, núm. 10, 213215 (Ardolino).

53-1662. Cotoner, Luisa (ed.) - El espejo y la máscara. Veinticinco años de ficción narrativa en la obra de Carmen Riera. Destino, Barcelona, 2000. II RFilR, 20 (2003), 297-301 (Juárez Morena).

\section{Riesco, Laura}

53-1663. Guardia, Sara Beatriz - "Ximena o la parábola de dos mundos". $T C, 2002$, núm. 10, 119-130. 
Ríos, Julián

53-1664. Pagès, Stéphane - Analyse $d u$ discours dans Larva (1984) de Julián Rios: le jeu de l'écriture, le jeu du roman. - Presses Universitaires du Septentrion, Villeneuve d'Ascq, 2001. 604 pp. II Ibero, 2003, núm. 9, 242-243 (Kunz).

Rivas, Manuel de las

53-1665. González ArCe, Teresa - "El texto migratorio: nota sobre la adaptación cinematográfica de tres cuentos de Manuel Rivas". - Alpha, 2004, núm. 20, 135-150.

\section{Rivera Garza, Cristina}

V. núm. 1593.

Rodríguez, Claudio

V. núm. 680.

\section{Rodríguez Juliá, Edgardo}

53-1666. Torres Caballero, Benjamín "La dinámica del erotismo en la obra de Edgardo Rodríguez Juliá”. ALM, 40 (2002), 293-330.

\section{Romero, José Rubén}

53-1667. Sánchez Medina, Gabriela - "José Rubén Romero, un intento de haikai". — TC, 2002, núm. 11, 201-214

\section{Romero Esteo, Miguel}

53-1668. Cornago Bernal, Óscar - "La escritura huérfana: Miguel Romero Esteo o la sublimidad del grotesco en la última vanguardia". - RLit, 64 (2002), 167-205.
Rulfo, Juan

53-1669. Eldave, Cecilia - "El llano en llamas: un universo en extensión y clausura". - Alpha, 2004, núm. 20, 267-272.

53-1670. Flores, R. M. - "De culebras y colores en «El hombre», de Juan Rulfo". - RCEH, 26 (2003), 439-453.

53-1671. Gordon, Samuel - "Cartas de Juan Rulfo a Mariana Frenk-Westheim". - LMM, 13 (2002), 255-268. 53-1672. Uscanga Constantino, Tomás "La intertextualidad como recurso estilístico en dos cuentos de Juan Rulfo". $-T C, 2002$, núm. 11, 189-200.

V. también núm. 1533.

\section{Sada, Daniel}

53-1673. Beltrán Félix, Geney - "El fabulador en octosílabos o el corridista culto. La prosa rítmica de Daniel Sada". - RLitPop, 2003, núm. 1, 117-140.

Saer, Juan José

53-1674. Premat, J. - La dicha de Salurno. Escritura y melancolia en la obra de Juan José Saer (N. 52-3130). II Ibero, 2003, núm. 11, 282-284 (Logie).

V. también núm. 1625.

\section{Sainz, Gustavo}

53-1675. Rodriguez Hernández, Sixto "La iniciación literaria de Gustavo Sainz". - TC, 2002, núm. 11, 169-176.

\section{Salinas, Pedro}

53-1676. Cuenca Toribio, José Manuel "Poesía y política en Pedro Salinas". —Ins, 2003, núm. 683, 6-9.

53-1677. Escartín Gual, Montserrat "Pedro Salinas: la letra y la persona". - RLit, 64 (2002), 555-566.

53-1678. Katz Crispin, Ruth - " la voz a ti debida and the poetics of translation". - Studies in honor of Denah 
Lida, eds. M. G. Berg \& Lanin A. Gyurko (Potomac, Maryland, 2005), pp. 217-225.

V. también núm. 1503.

\section{Sánchez, Luis Rafael}

53-1679. Perivolaris, J. D. - Puerto Rican cultural identity and the work of Luis Rafael Sánchez (N. 51-3148). II Ibero, 2003, núm. 9, 258-259 (Herlinghaus). - V. núm. 52-3135.

\section{Sanchís Sinisterra, José}

53-1680. Saval, José-Vicente - “ $i A y, ~ C a r-$ mela!, reivindicación de la República, reivindicación de la mujer". - $R N o$, 43 (2002), 85-90.

\section{Sastre, Alfonso}

V. núm. 1472.

Segovia, Tomás

53-1681. Pascual Gay, Juan - "Ceremo nial del moroso: el poema evoca y convoca". - $T C, 2003$, núm. 12, 85-93.

V. también núm. 1450.

\section{Semprín, Jorge}

V. núm. 767.

\section{Sepúlveda, Luis}

53-1682. Casini, Silvia - "Luis Sepúlveda: un viaje express al corazón de la Patagonia". - Alpha, 2004, núm. 20, 103-120.

\section{Soca, Susana}

V. núm. 1375.
Tablada, JoséJuan

53-1683. Cisneros, Odile - "El oriente de dos mexicanos: Japón en la obra de Tablada y Rebolledo". - LMM, 13 (2002), 91-116.

\section{Torre, Guillermo de}

V. núm. 1408.

Torres, Ana Teresa

V. núms. 1321, 1322.

Torri, Julio

53-1684. Olea Franco, Rafael - "Un lujo mexicano: Julio Torri". - Carav, 2002, núm. 78, 143-161.

\section{Umbral, Francisco}

V. núm. 768.

\section{Unamuno, Miguel de}

53-1685. Escobar Borrego, Francisco JAvier - "El concepto de intrahistoria como praxis periodística en $A n$ danzas y visiones españolas, de Miguel de Unamuno". - AEF, 26 (2003), 103-116.

53-1686. Glerrero, Vladimir - "Diégesis y realidad en Niebla". - RRo, 36 (2001), 255-264.

53-1687. Martínez, Alejandro - Lenguaje y dialogía en la obra de Unamuno. Pliegos, Madrid, 1998. 173 pp. II $R C E H, 26$ (2002), 569-571 (LaRubiaPrado).

53-1688. Verbeke, FrederiK - "La entrevista de Johan Brouwer con Miguel de Unamuno en septiembre de 1936 (I)". —Íns, 2003, núm. 682, 6-8.

V. también núms. 1550, 1568. 
Uslar Pietri, Arturo

53-1689. Webster, Arturo UsLar - De la cultura de desigualdad al espacio de violencia en la novelística de Arturo Uslar Pietri. - The Edwin Mellen Press, Lewiston, N.Y., 2001. xviii + 180 pp. II Ibero, 2003, núm. 11, p. 276 (Gewecke).

\section{Valdelomar, Abraham}

53-1690. Bervabé, Mónica - "Dandismo y rebeldía en el Perú: el caso de Abraham Valdelomar". - Ibero, 2003, núm. 11, 41-63.

\section{Valdés, Zoé}

53-1691. RAMSDEIL, LEA - "Life is a bolero: Te di la vida entera by Zoé Valdés". — Brújula, 3 (2004), núm. 1, 113-123.

\section{Valdivieso, Mercedes}

53-1692. Guerra, LuCíA - "Maldita yo entre las mujeres de Mercedes Valdivieso: resemantización de la Quintrala, figura del Mal y del exceso para la «chilenidad a apolínea”. - TC, 2002, núm. 10, 55-73.

\section{Valente, José Ángel}

53-1693. Borja Rodríguez, María José "El latido de la palabra en Mandorla, de José Ángel Valente". - EHF, 26 (2004), 55-66.

53-1694. Díaz, Susana - "Notas para una poética de José Ángel Valente". BHH, 2004, núm. 4, 27-53.

53-1695. Pernado Eli.jot, Carlos - "Arquitectura y fragmento. Análisis del El fulgor de José Ángel Valente". RLit, 65 (2003), 501-530.

V. también núm. 614.

Valenzuela, Luisa

V. núm. 1625.
Valle-Inclán, Ramón del

53-1696. Dovgherty, Dre - Palimpsestos al cubo: prácticas discursivas de Valle-Inclán. - Fundamentos, Madrid, 2003. 266 pp. II RLit, 65 (2003), 655-659 (García Pascual).

53-1697. NúNez SaBarís, XaQuín - La novela corta en Valle-Inclán. Estudio textual de "Femeninas". - Universidade, Santiago de Compostela, 2005. 293 pp.

53-1698. Trecca, Simone - "La tópica esperpéntica en el discurso descriptivo de las acotaciones en Martes de carnaval". - Criticón, 2003, núms. $87 / 88 / 89,865-875$.

V. también núms. 603, 1362.

\section{Vallejo, César}

53-1699. Gómez López-Quñones, ANtoNiO - "Religión y revolución en César Vallejo: España, aparta de mi este cáliz". - TC, 2003, núm. 12, 61-72.

53-1700. Lemaître, MoniQue J. - Viaje a "Trilce". - Plaza y Valdés, México, 2001. 253 pp. II TC, 2002, núm. 11, 295-302 (Rodríguez Hernández).

\section{Vargas Llosa, Mario}

53-1701. Barrleto, Jorge - "Vargas Llosa's Heart of darkness: Travelling tropes in the construction of indigenous identity". - Brújula, 3 (2004), núm. 1, 69-83.

53-1702. Cadera, Susanne M. - Dargestellte Mündlichkeit in Romanen von $M a$ rio Vargas Llosa. - Droz, Genève, 2002. 320 pp. II Ibero, 2003, núm. 11, 276-280 (Gnutzmann); VR, 62 (2003), 349-351 (Schor).

53-1703. Henighan, Stephen - "Mad land, my land: The problem of national identity in Vargas Llosa's La casa verde ". - RCEH, 27 (2003), 253-270.

53-1704. Kölluann, Sabine - Vargas Llosa's fiction and the demons of politics. $-\mathrm{P}$. Lang, Oxford, 2002. 314 pp. II Ibero, 2003, núm. 11, 276-280 (Gnutzmann). 53-1705. KöNig, BRigitTe - Speech appeal. Metasprache und fingierte Mündlichkeit 
im Werk von Mario Vargaś Llosa. Narr, Tübingen, 2002. 353 pp. II Ibero, 2003, núm. 11, 276-280 (Gnutzmann).

53-1706. Morales Saravia, J. (ed.) - Das literarische Werk von Mario Vargas Llosa. Akten des Colloquiums im IberoAmerikanischen Institut Berlin, 5.-7. November 1998 (N. 50-1500). II RF, 115 (2003), 277-278 (Merkl). - V. núm. 51-1604.

53-1707. Muñoz, Braulio - A storyteller. Mario Vargas Llosa between civilization and barbarism. - Rowman \& Littlefield, Lanham, 2000. 135 pp. II Ibero, 2003, núm. 11, 276-280 (Gnutzmann).

V. también núms. 1326, 1478.

\section{Vázquez Montalbán, Manuel}

53-1708. Bayó Belenguer, Susana - "A moral chronicle: The Carvalho series of Manuel Vázquez Montalbán”. $R N o, 43$ (2002), 23-35.

53-1709. BODenmüller, Thomas - "Manuel Vázquez Montalbán: Galíndez (1990)". - Romane in Spanien. T. 1: 1975-2000, eds. T. Bodenmüller, T. M. Scheerer \& A. Schönberger (Frankfurt/M., 2004), pp. 127-149.

\section{Vicens, Josefina}

53-1710. Reyes Córdoba, Bladimir "Un acercamiento a Los años falsos de Josefina Vicens". - TC, 2002, núm. $11,177-188$.

\section{Vila-Matas, Enrique}

53-1711. Sivche7, Yutte - "Enrique Vila-Matas: Bartleby y compañí (2000)". - Romane in Spanien. T. 1: 19752000 , eds. T. Bodenmüller, T. M. Scheerer \& A. Schönberger (Frankfurt/M., 2004), pp. 315-327.
Villoro, Juan

53-1712. Villoro, JuAN - Efectos personales. - Anagrama, Barcelona, 2001. 251 pp. II Ibero, 2003, núm. 12, 244246 (Hartwig).

\section{Volpi, Jorge}

53-1713. Navarrete González, Carolina ANDREA - "Analogía demencial en el modo de representación de $\mathrm{El}$ fin de la locura de Jorge Volpi". - Alpha, 2004, núm. 20, 91-101.

\section{Williams, Carlos W.}

53-1714. Ramos, Julio - "El Dr. William C. Williams bajo el sol de Río Piedras". - EUSB, 2003-04, núms. 22/23, 361-380.

Yáñez, Agustin

V. núm. 1363.

\section{Zambrano, María}

53-1715. Pino Campos, Luss Miguel "Afrodita y Eros: dos mitos clásicos en los orígenes de la filosofia de María Zambrano". - RFLL, 22 (2004), 247-271.

\section{Zunzunegui, Juan Antonio de}

53-1716. ZL XeLNegCI, JLAN ANTONIO DELa vida es como es. Ed. de Pilar García Madrazo. - Castalia, Madrid, 2000. 892 pp. II RCEH, 27 (2003), 608-610 (Eustis). 